http://dx.doi.org/10.18778/7525-678-9

JAN MUŚ

MARTA SZPALA

\title{
Chorwacja
}

\section{w Unii Europejskiej}

Croatia in the

European Union 


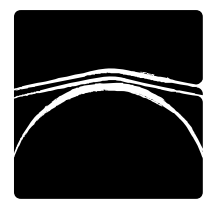

SERIA WYDAWNICZA "BAŁKANY XX/XXI” 


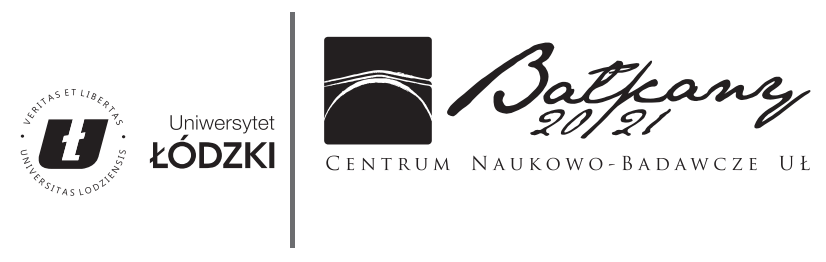

JAN MUŚ

MARTA SZPALA

\section{Chorwacja \\ w Unii Europejskiej}

\section{Croatia in the}

European Union 


\title{
REDAKCJA MERYTORYCZNA \\ Pawet Chmielewski \\ Stawomir Lucjan Szczesio
}

\author{
RECENZENT \\ Jacek Wojnicki \\ KOREKTA \\ Bogustaw Pielat \\ T€UMACZENIE \\ Martyna Bojarska \\ OKŁADKE PROJEKTOWAŁA \\ Barbara Grzejszczak \\ SKŁAD I ŁAMANIE \\ ESUS - Agnieszka Buszewska
}

(c) Copyright by Uniwersytet Łódzki - Wydawnictwo Uniwersytetu Łódzkiego 2011

Wydawnictwo Uniwersytetu Łódzkiego

90-131 Łódź, ul. Lindleya 8

Wydanie I. Nakład 400 egz. Ark. druk. 11,0

Zam. 5022/2012. Cena zł 28,- + VAT

ISBN 978-83-7525-678-9 


\section{Spis treści}

¡łowo wstępne Jego Ekscelencji Ambasadora Republiki Chorwacji w Polsce

?rzedmowa

lozdział I

\horwacja wczoraj i dzisiaj

?ozdział II

خhorwacka droga do Unii Europejskiej

lozdział III

¿horwacja w Unii Europejskiej ................................................. 37

Ispekty instytucjonalne …............................................................ 37

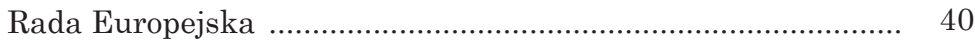

Rada Unii Europejskiej ............................................................ 41

Parlament Europejski ............................................................. 43

Komisja Europejska ........................................................... 44

Chorwaci w pozostałych instytucjach Unii Europejskiej .......... 44

tspekty gospodarcze i finansowe ................................................... 45

Budżet Unii Europejskiej …................................................ 45

Wspólna Polityka Rolna .......................................................... 4

Polityka spójności .................................................................... 51

Polityka energetyczna .............................................................. 53

Polityka klimatyczna ............................................................ 55

Vspółpraca w dziedzinie polityki zagranicznej .............................. 56

Vyzwania stojące przed Chorwacja _............................................. 58

lozdział IV

Jonkluzje i wnioski dla Polski .................................................... 63

Vskazówki bibliograficzne ........................................................ 67 


\section{Załączniki}

1. Chronologia integracji Chorwacji z Unią Europejską ........... 71

2. Tabela negocjacji poszczególnych rozdziałów akcesyjnych ..... 83

3. Programy Unii Europejskiej, w których uczestniczy Chorwacja …....................................................................... 89

4. Chorwaccy przywódcy w latach 1991-2011 .......................... 89 


\section{Słowo wstępne Jego Ekscelencji Ambasadora Republiki Chorwacji w Polsce}

Nasz kraj znajduje się przed realizacja jednego z kluczowych priorytetów polityki zagranicznej i przed osiagnięciem swojego fundamentalnego celu, jakim jest pełnoprawne członkostwo w Unii Europejskiej, rdzeniu trwałego pokoju, demokratycznych wolności, ekonomicznego rozwoju i społecznego dobrobytu.

W czasie wieloletniego procesu negocjacyjnego społeczeństwo chorwackie musiało przejść głęboką przemianę, nie tylko $\mathrm{w}$ rozumieniu dostosowania prawnych ram poprzez przyjęcie acquis communitaire, ale, co ważniejsze, przez całościowa reformę wielu sektorów. Kontynuujemy wysiłki mające na celu stworzenie skutecznego wymiaru sprawiedliwości i funkcjonalnego państwa prawa, efektywnej administracji, pełnego spełnienia warunków funkcjonowania konkurencyjnego rynku, przy jednoczesnej polityce zera tolerancji dla korupcji. Odnośnie do procesu dalszych reform istnieje polityczna zgoda i pełne zaangażowanie wszystkich odpowiednich czynników społecznych.

Wyjątkowo cieszy nas fakt, że traktat akcesyjny podpiszemy właśnie w czasie polskiej prezydencji w Unii. W ten sposób pogłębimy wszystkie wymiary naszych stosunków dwustronnych oraz wzmocnimy łączące nas przyjacielskie więzi, które sięgają daleko w przeszłość. Nadamy im także nowe znaczenie, tym razem w kontekście współpracy w Unii Europejskiej.

Chorwacja rozumie Ideę Europejska jako wspólnotę narodów i państw europejskich budujących przyszłość oparta 
na wspólnych wartościach i zasadach, a jednocześnie zachowujacych państwowe, narodowe, polityczne, kulturowe i ekonomiczne różnice.

System wartości UE najlepiej wyraża interesy chorwackiego państwa i społeczeństwa, a wartości te będą najlepiej chronione właśnie dzięki pełnemu włączeniu w proces integracji europejskiej. Analiza kosztów i korzyści wejścia do Unii pokazuje, że w okresie długoterminowym Chorwacja zyska na członkostwie w UE. Ocenia się bowiem, że potencjalny rozwój gospodarczy, polityczny, naukowo-kulturowy i ogólny Republiki Chorwacji jest większy wewnątrz niż na zewnatrz Unii.

Jestem przekonany, że chorwaccy obywatele przekonaja się o tym i że wynik referendum o przystapieniu Chorwacji do Unii Europejskiej będzie pozytywny, co zresztą sugeruja rezultaty badania opinii publicznej, które pokazują stałe poparcie dla Unii*.

Jest mi wyjątkowo miło, że taka publikacja została przygotowana właśnie w czasie trwania polskiej prezydencji. Przyczyni się ona do lepszego zrozumienia zarówno procesu negocjacji i akcesji Chorwacji do UE, jak i poznania potencjału korzystnej współpracy Polski i Chorwacji na forum Unii Europejskiej.

Ivan Del Vechio Ambasador Republiki Chorwacji w Polsce

Warszawa, listopad 2011 r.

* Od Redakcji: po oddaniu tekstu publikacji do druku, 22 stycznia 2012 r., ponad 66\% Chorwatów głosujących w referendum opowiedziało się za wejściem do UE (przy frekwencji 43,5\%). 


\section{Przedmowa}

Centrum Naukowo-Badawcze UŁ „Bałkany na przełomie XX/XXI w.” oddaje do rak Czytelnika pozycję autorstwa tandemu Jan Muś - Marta Szpala, przybliżająca ogólna wiedzę o pozycji Chorwacji na progu jej członkostwa w Unii Europejskiej.

Użyty w tytule swoistego przewodnika czas „przyszły dokonany" stanowi nie tylko projekcję zdarzeń oczekiwanych, jest też dowodem życzliwości i sympatii dla społeczeństwa tego państwa. Obie owe cnoty każą odnieść się z uznaniem do postępów Chorwacji w dziele zmian zachodzących w sposobie urządzenia wewnętrznego, normalizacji stosunków z sassiadami (w tym ościennymi, z dalszymi problemy odnotowywano rzadziej), przydawania wreszcie coraz większej wagi implementacji rozwiązań funkcjonujacych w tradycji zachodniej hemisfery.

Nie sposób nie docenić wysiłków w tej materii podejmowanych po roku 1999, pozytywnie zweryfikowanych przez Komisję Europejska w wydanym w 2004 r. avis w sprawie wniosku o członkostwo w Unii, konkretyzujących się w nakreślonych rok później Ramach Negocjacyjnych. Procesowi akcesyjnemu na etapie uzgodnień co do zasad i pryncypiów oraz realizacji wstępnego programu ciążyła znacząco niechęć Zagrzebia do rzeczywistej współpracy z Międzynarodowym Trybunałem Karnym dla byłej Jugosławii oraz zbyt wolne tempo normalizacji stosunków z „bliską zagranica” - zwłaszcza z Serbia.

Wymuszone na rządzie, przez przychodzące w sukurs Hadze czynniki w Brukseli, ustępstwa - głownie w pierw- 
szym segmencie spraw, pozwoliły jesienia 2005 r. na ustalenie procedur negocjacji oraz zbliżenie się stron w kwestii harmonogramu prac. Godzi się zauważyć, że niepoślednią rolę $\mathrm{w}$ procesie przemian i przezwyciężania skutków wojny na obszarze byłej Jugosławii, w tym poniesionych strat, odegrało zaproszenie Chorwacji (wraz z Albania) do Sojuszu Północnoatlantyckiego na bukareszteńskim szczycie 2008 r., czyniace oba państwa członkami NATO na początku kwietnia roku następnego.

Strategicznemu celowi - przyspieszenia procesu integracji z Unia, w obliczu coraz słabszej kondycji gospodarczej kraju, zdawały się podporządkowywać przedsięwzięcia barwnego gabinetu Ivo Sanadera. Równie szeroka, co dość niezwykła, jak na ten region koalicja zaktywizowała się m. in. na polu polityki regionalnej i narodowościowej, nie była jednak w stanie powstrzymać narastania kryzysu, co gorsza - mimo spektakularnych gestów, brakowało jej woli i zdecydowania, by przeciwstawić się walce z przestępczością zorganizowana, wszechobecną korupcja, wreszcie wykazania się postawą koncyliacyjną w relacjach ze Słowenia.

W sukcesy tego okresu wpisywały się inwestycje infrastrukturalne, jak budowa sieci nowoczesnych autostrad, wyprzedzająca wiele spośród unijnych państw członkowskich modernizacja kolei, wprowadzenie sensownych regulatyw w sektorze ochrony zdrowia i opieki społecznej. Problemem pozostawał pakiet spraw związanych z wymiarem sprawiedliwości, obejmujący nie tylko nieskuteczność prób w zakresie reformy sądownictwa, brak instytucji arbitrażu, przemożny wpływ oligarchów i osób wywodzących się z partyjnego (HDZ) i wojskowego establishmentu na sposób rozstrzygania sporów oraz orzecznictwo w kwestiach gospodarczych. Z uwagi na promujacy charakter przedkładanego opracowania, pozostaje zawrzeć w niniejszym wstępie przekonanie, że mankamentom tym, manifestującym się w życiu publicznym także i obecnie, łatwiej będzie przeciwstawić się w ramach 28-członowej agregacji. 
Byłoby uproszczeniem podnoszonego problemu sprowadzenie go do konstatacji o plasowaniu się sądownictwa pośród korupcyjnych liderów(!) czy stosowania wymiaru sprawiedliwości w sposób nader wybiorczy. Sądy i prokuratura należą do tych chorwackich instytucji, w których zachodza, począwszy od pierwszych przegranych przez HDZ w styczniu 2000 r. wyborów, istotne, chociaż nie nazbyt konsekwentnie realizowane, zmiany. Rzadziej odnotowuje się liczne wcześniej naruszenia etyki sędziowskiej, fałszowanie dokumentów procesowych (np. jako efekt silnej presji politycznej na sędziów i podejmowane przez nich decyzje).

Postępy Chorwacji na drodze do Unii każą wierzyć w projekcję lepszej kondycji prawa, czy - jak chciał tamtejszy Prezes Sadu Najwyższego - „odpolitycznienie sądów i uczynienie z nich faktycznej, trzeciej władzy". Jej stan, jak w ocenie sprzed dekady, pozostaje wprawdzie „złożony", i, chociaż odwrotnie niż wtedy, $z$ widokami na poprawę. Póki co, pamiętajac o perturbacjach z „bilansem otwarcia” w krajach „nowej” Unii, trzeba pogodzić się z faktem, że Chorwacja przystapi do niej dysponując (przynajmniej przez czas jakiś) standardami obowiąującymi np. w niektórych z państw nastałych w miejscu sowieckich republik „na wschód od Kijowa”.

Unia Europejska określa ramy i pożądane kierunki polityki, jej najogólniejsze cele i założenia rozwojowe. Nie narzuca wszakże państwom członkowskim rozwiązań „sztywnych”. Z drugiej strony nie oznacza to, by przystapienie do układu transeuropejskiego nie generowało potrzeby uwzględnienia brukselskich zaleceń i ustaleń, chociaż pozostawia polityce Chorwacji, jak i każdego innego kraju, formułowanie własnych zamierzeń rozwojowych i określanie sposobów ich urzeczywistnienia.

Znakomita większość społeczeństwa nad Sawa i Adriatykiem ma świadomość, że obok korzyści płynących z członkostwa w UE, warunkiem wzrostu poziomu życia i pomyślniejszych perspektyw jest praworządność 
i poszanowanie prawa oraz społecznego dobra. Wie też, że fundamentalną zasadę moralności społecznej określać winien priorytet obowiązków względem drugiego człowieka, nie zaś wobec stołecznych czy lokalnych baronów, niezależnie od tego, jak wielkie były ich wskrzesicielskie zasługi.

Przyjaciele narodów Słowiańszczyzny Południowej, w tym - co oczywiste - ich zachodnich rubieży, chca wierzyć, ze hierarchia służebności i użyteczności publicznej wyznaczać tam będzie już wkrótce gradację pozycji społecznej. Pozwoli to na cofnięcie przyzwolenia na podział Republiki na strefy wpływów, a walka z patologiami społecznymi, rozwój, w tym rozważne gospodarowanie zasobami, stana się elementami nowocześnie pojmowanego bezpieczeństwa narodowego zamiast budowania psychoz zagrożenia przez sąsiadów.

Parafrazując słowa wybitnego humanisty prof. Tadeusza Kotarbińskiego, starajmy się postrzegać Chorwację, jaką stać się ona może w nieodległej przyszłości, niekoniecznie zaś taka, jakiej obraz jawi się nam dziś. Zamiast więc wtórować sceptykom deliberującym o szansach na „sądy niezawisłe i media wolne”, lepiej dokumentować nasze polskie (chociaż nie tylko z racji prezydencji, pod która Traktat akcesyjny, 9 grudnia 2011 r., został podpisany) poparcie dla słusznych aspiracji Chorwatów - pozytywami. Przykładem właściwego kierunku procesu zmian jest chociażby odejście od inżynieringu wyborczego, nagminnie stosowanego w pierwszej „dekadzie wolności” w postaci manipulacji w prawie, łączenia okręgów z silna opozycją z jednostkami administracyjnymi wyraźnie popierajaccymi partię rządząca, zrezygnowanie $\mathrm{z}$ funkcji eksponenta listy, tj. osoby de facto nie kandydującej itd. Już ordynacja z 2006 r. zredukowała możliwości nadużyć w postaci manipulowania głosami diaspory, stosowania opcji „podwójnej”, a końcówka dekady pozwoliła chociażby na umocnienie się samorządów terytorialnych. W kwestii polityki historycznej, w odróżnieniu od poprzedników, prezydent Ivo Josipović najdalszy 
jest od głoszenia peanów na cześć tworu paweliciowskiego, a spikerom Saboru nie przychodzi do głowy, by wzorem jego przewodniczącego z pierwszej połowy lat 90. podnosić z sejmowej mównicy „szlachetne cechy faszyzmu”. Czyż społeczeństwu zmęczonemu resentymentami i „służbową" demagogia, kreowaniem domorosłych tycoons zwiazanych z obozem władzy, aferami na jej szczycie, odmówić można unijnego remedium?

Godzi się pamiętać, że Chorwaci absorbowali w swojej trudnej historii i adaptowali do własnych warunków wartości kultury europejskiej, a elity narodowe kształtowały się pod wpływem wspólnych nowożytnych tradycji filozofii, nauki i sztuki... Wzbogacały treści myśli oświeceniowej i idee romantyzmu, pozytywizmu, wpisując się w hasła liberalizmu czy zjawiska rewolucji przemysłowej i postępu naukowo-technicznego. Etnozbiorowość, którą na starcie niezawisłego bytu dramatycznie przed wiekami resursu własnej państwowości pozbawiono, skazując na próby jej restytuowania niekiedy heroiczne, kiedy indziej całkowicie chybione, ukorzeniała się w europejskiej spuściźnie intelektualnej, hołdowaniu ideałom katolicyzmu, niepodległości, rodziny.

Integracja wyznacza lepsze dla Chorwatów perspektywy ekonomiczne i możliwości rozwojowe - w tym korzystania ze zdobyczy państw bardziej rozwiniętych. Przestrzeń transeuropejska, niezależnie od zachodzacych w niej turbulencji, tworzy warunki poprawy egzystencji, przeprowadzenia reform strukturalnych, skorzystania ze wspólnotowych instrumentów finansowych. Członkostwo nie limituje narodowej różnorodności ani realizacji podstawowych wartości racji stanu, łącząc - co ma w tym przypadku znaczenie fundamentalne - podmioty procesu w poszanowaniu demokracji, praworządności, wolnego rynku i praw człowieka. Uczestnictwo w tym ładzie samo w sobie nie jest panaceum na uporanie się z problemami identyfikacji, megalomanię i ksenofobię, wynaturzone partyjnictwo, pobudliwość czy 
emocjonalizm, pomaga jednakże w całokształcie spraw przywarom tym stawiać tamę. Wraz z czynionymi w ostatnim czasie wysiłkami na rzecz przeobrażeń społeczno-politycznych, a także sprostania wyzwaniom akcesyjnym, tworzy to grunt pod literę Traktatu, następnie jego ratyfikację w krajach członkowskich (oraz w Zagrzebiu) i przystapienie Republiki Chorwacji, 1 lipca 2013 r., do Unii Europejskiej.

Prof. nadzw. dr hab. Wiestaw Walkiewicz*

Przewodniczacy Rady Naukowej Centrum Naukowo-Badawczego U乇 „Bałkany na przełomie XX/XXI w.”

Łódź-Warszawa, grudzień 2011 r.

*Ambasador Rzeczpospolitej Polskiej w Republice Chorwacji w latach 1993-1997. 


\section{Rozdział I \\ Chorwacja wczoraj i dzisiaj}

Dzisiejsza Chorwacja jest $\mathrm{w}$ wielu aspektach podobna do Polski - zmierzyć się musi bowiem z wieloma podobnymi problemami społecznymi, politycznymi czy gospodarczymi, charakterystycznymi dla państw epoki transformacji. Specyficzne tło historyczne spowodowało jednak, że istnieje kilka zasadniczych różnic, które należy podkreślić.

W czasach średniowiecza Chorwacja stosunkowo szybko została zdominowana przez węgierskich sąsiadów najpierw przez państwo Arpadów, a następnie wchłonięta przez monarchię Habsburgów. Poczucie przynależności narodowej Chorwatów kształtowało się w związku z walką z madziaryzacja, ale także z Imperium Osmańskim. Budzenie się świadomości narodowej Słowian południowych w XIX w. doprowadziło do wysunięcia wielu propozycji dotyczących kształtu przyszłego państwa chorwackiego. Część z nich odnosiła się do utworzenia trzeciej - słowiańskiej - części monarchii habsburskiej, składającej się wówczas z Austrii i Węgier. Inne propozycje przykładały większą wagę do utworzenia samodzielnego państwa chorwackiego. Dużą popularnością cieszył się ruch, który zmierzał ku zjednoczeniu Słowian Południowych w jednym państwie. Tym, co różni historię Polski i Chorwacji, jest podział narodów słowiańskich zamieszkujaccych półwysep na katolicki zachód i prawosławny wschód. Mozaika etniczna ziem, które dziś stanowią Chorwację oraz przylegające 
do niej Bośnię i Hercegowinę, Czarnogórę i Serbię, nie pozwalała na utworzenie silnych, a jednocześnie homogenicznych, państw narodowych. Z drugiej jednak strony, bliskość etniczna Słowian Południowych sprawiała, że można było z ufnościa patrzeć na projekt przyszłego wspólnego państwa. Połączenie ziem słowiańskich w jeden byt polityczny pozwalało prawosławnym Serbom zamieszkującym Chorwację czy katolickim Chorwatom w Bośni i Hercegowinie pozostać w granicach państwa, które uznać mogli za swoje.

Królestwo Serbów, Chorwatów i Słoweńców, jak oficjalnie (do 1929 r.) nazywano monarchię jugosłowiańska, nie przetrwało ciężkiej próby dwudziestolecia międzywojennego. Trudno stwierdzić kto, albo szerzej - która ze stron ponosiła główną odpowiedzialność za taki stan rzeczy. Faktem pozostaje jednak, że dominująca oś sporu przebiegała między serbskimi centrystami a chorwackimi autonomistami. Z biegiem lat konflikt ten przybierał coraz ostrzejsze formy, łącznie z zabójstwem chorwackiego przywódcy Stjepana Radicia w parlamencie w 1928 r., wprowadzaniem od 1929 r. rządów autorytarnych czy wreszcie zabójstwem samego króla Jugosławii Aleksandra I Karađorđevicia w roku 1934. Warto jednak wspomnieć o porozumieniu z sierpnia 1939 r., w wyniku którego Chorwacja otrzymała znaczą autonomię w ramach państwa jugosłowiańskiego ${ }^{1}$.

Negatywne doświadczenie współpracy z Belgradem lat 20. i 30. ubiegłego stulecia pchnęło Chorwatów w objęcia państw Osi. Rezultatem tego była tragedia, jaka rozegrała się w czasie II wojny światowej na ziemiach Chorwacji, Bośni i Hercegowiny oraz Serbii, gdzie oddziały chorwackich faszystów (ustaszy) dokonywały zbrodni zarówno na nie-Chorwatach, jak i na chorwackich opozycjonistach.

${ }^{1}$ Było to tzw. porozumienie Cvetković-Maček. Utworzono wówczas Banowinę Chorwacką, która funkcjonowała jednak tylko do wybuchu wojny w kwietniu $1941 \mathrm{r}$. 
Charakter zwycięskiego ruchu partyzanckiego marszałka Josipa Broz-Tito oznaczał, że nowe powojenne państwo, jakkolwiek autorytarne w swoim charakterze, weźmie pod uwagę specyfikę wielonarodowościowej federacji i odstąpi od centralizmu dominujacego w czasie tzw. pierwszej Jugosławii.

Federacja jugosłowiańska rzeczywiście połączyła i na lata pogodziła zwaśnione kiedyś strony w ramach wspólnego państwa z systemem jednopartyjnym. Jugosławia kojarzyła się w Polsce dobrze nie tylko dzięki Jugosłowianom, ale także dobrobytowi i pozornemu blichtrowi materialnemu, którego tak brakowało w Polsce Ludowej. Spędzając wczasy np. w Dalmacji można było poczuć klimat Zachodu, pozostając wśród ludzi przypominających jednak charakterem i temperamentem Polaków bardziej niż Francuzi, Włosi czy Niemcy. Ten swoisty ,jugosłowiański sen” (patrząc z perspektywy globalnej można pokusić się o stwierdzenie, że i paradoks), możliwy był dzięki dwóm czynnikom. Po pierwsze, Jugosławia, chcąc nie chcąc, znalazła się pomiędzy blokiem wschodnim (komunistycznym) i zachodnim (kapitalistycznym) ${ }^{2}$. Marszałek Tito, razem z prezydentami Indonezji - Achmadem Sukarno, Egiptu - Gamalem A. Naserem oraz Indii - Jawaharlelem Nehru stworzyli tzw. ruch państw niezaangażowanych ${ }^{3}$, który w swoich założeniach miał stać z boku toczącej się „zimnej wojny”. Pozwoliło to członkom ruchu na zachowanie stosunkowej niezależności od wielkich mocarstw oraz na wygrywanie różnic między blokami. Dotacje, kredyty i pożyczki świata

${ }^{2}$ Warto pamiętać, że Jugosławia do 1948 r. była nazywana „satelitą numer jeden” ZSRR, jednak w wyniku konfliktu z Moskwą została wyrzucona z Kominformu i zaczęła funkcjonować poza blokiem państw podporządkowanych Związkowi Radzieckiemu.

${ }^{3}$ Zrzeszający obecnie 118 państw członkowskich oraz 18 państw i 10 organizacji posiadających status obserwatora (w tym Bośnia i Hercegowina, Chorwacja, Czarnogóra i Serbia), http://www.namegypt. org/en/AboutName/MembersObserversAndGuests/Pages/default.aspx. 
zachodniego utrzymać miały Jugosławię w bezpiecznej odległości od Moskwy. Ruch państw niezaangażowanych, obejmujący praktycznie cała Afrykę, Amerykę Łacińska oraz znaczną część Azji Południowo-Wschodniej, doprowadził do zwiększenia wymiany handlowej Jugosławii, np. z krajami afrykańskimi i arabskimi. Załamanie się tych rynków w latach 70. zmusiło przemysł jugosłowiański do przeorientowania się na Zachód. Dzięki temu Chorwacja i Słowenia zyskały dużo większe znaczenie. W Chorwacji szczególnie widoczny był napływ tzw. dewizowych turystów z Zachodu, którzy począwszy od lat 70. masowo przybywali nad wybrzeże Morza Adriatyckiego.

Drugim czynnikiem, wywołującym pewnego rodzaju fascynację wśród Polaków, była gospodarcza liberalizacja oraz administracyjna i do pewnego stopnia polityczna decentralizacja kraju. Pozwoliło to republikom, takim jak Chorwacja czy Słowenia, na szybki i trwały rozwój gospodarczy, a dzięki temu na podniesienie poziomu życia w odniesieniu do biednego południa kraju. Przyjęty już w latach 50., a następnie rozwijany samorządowy system produkcji przez długi czas przynosił znakomite efekty, uelastyczniając produkcję i czyniąc ją bardziej czułą na zmiany i potrzeby rynku, czego np. nie można było powiedzieć o centralnie sterowanej gospodarce ówczesnej Polski. Śmierć marszałka Tito i koniec „zimnej wojny” wymusiły liberalizację polityczną, a pogłębiające się różnice w rozwoju gospodarczym poszczególnych republik oraz dojście do władzy nacjonalistów doprowadziły wkrótce do ostrego konfliktu pomiędzy przywódcami poszczególnych republik, a w konsekwencji do wojny i dezintegracji Jugosławii.

Tragedia rozpadu federacji jugosłowiańskiej zaskoczyła większość opinii światowej, natomiast rola i wkład poszczególnych republik i ich przywódców, włączając w to także Chorwację i jej ówczesnego prezydenta Franjo Tuđmana, pozostaja w dalszym ciagu przedmiotem sporu. Czy Serbowie chorwaccy wraz ze Slobodanem Miloševiciem 
sprowokowali władze w Zagrzebiu do ostrej kontrakcji? Czy może to nacjonalistyczna retoryka Tuđmana doprowadziła do wzrostu nieufności pomiędzy tymi dwoma grupami? Jaką rolę odegrała Chorwacja w czasie wojny w Bośni i Hercegowinie? Czy zachowała względną neutralność? Czy może była jedna z walczących stron? Czy wojska chorwackie dokonywały zbrodni na serbskiej i boszniackiej ludności cywilnej? Jaki miała przebieg operacja „Burza”, kończąca byt niezależnego terytorium serbskiego na obszarze Chorwacji w 1995 r.? ${ }^{4}$ Czy Tuđman i inni przywódcy okresu wojny zasługują na potępienie, czy może są bohaterami narodowymi - ojcami niepodległości chorwackiej?

Te i inne pytania nie traca aktualności również obecnie i dzielą chorwackie społeczeństwo i scenę polityczna. Sam proces demokratyzacji zakończył się stosunkowo późno, bo dopiero w latach 2000-2001, po śmierci Tuđmana i zmianie stylu rządzenia $\mathrm{z}$ autorytarnego na demokratyczny. Paradoksalnie, transformacja trwała stosunkowo długo ze względu na brak opozycji wobec systemu. Relatywny dobrobyt gospodarczy oraz stosunkowo, w porównaniu z państwami bloku wschodniego, a szczególnie Bułgaria, Rumunią czy Albania, liberalny system polityczny, nie stanowiły zachęty do wytworzenia się szerokich elit opozycyjnych w takim zakresie, jak to działo się w Polsce, Czechosłowacji czy na Węgrzech. W całej prawie Jugosławii komunistyczne elity wyjątkowo często przybierały maskę nacjonalizmu, który - przy istniejących różnicach etnicznych - trafił na wyjątkowo podatny grunt. To właśnie odsunięcie od władzy ekipy Tuđmana uznać należy za „otwarcie drzwi” do Unii Europejskiej.

Funkcjonujący obecnie system polityczny stał się sceną walki dwóch głównych ugrupowań politycznych. Sa to: Socjaldemokratyczna Partia Chorwacji (Socijaldemokratska

${ }^{4} \mathrm{Z}$ wyjątkiem tzw. wschodniej Slawonii, która powróciła pod kontrolę Zagrzebia w $1998 \mathrm{r}$. 
partija Hrvatske, SDP) oraz chadecka Chorwacka Wspólnota Demokratyczna (Hrvatska demokratska zajednica, HDZ). Obydwie te partie, podobnie jak kilka mniejszych, mających swoich przedstawicieli ${ }^{5} \mathrm{w}$ chorwackim parlamencie Saborze, popierają integrację Chorwacji z Unią Europejska. Od 1990 r. władzę sprawowała głównie HDZ, z wyjątkiem lat 1991-1992, kiedy to utworzono rząd jedności narodowej oraz lat 2000-2003, kiedy władzę przejęli socjaldemokraci ${ }^{6}$. W grudniu 2011 r. w wyborach parlamentarnych zwyciężyła opozycyjna i centrolewicowa Koalicja Kukuriku, której najsilniejszą partia jest SDP.

System rządów w republice jest stabilny, ze stosunkowo dobrze funkcjonujaca administracja, egzekutywa, głowa państwa oraz jednoizbowym parlamentem. Problemem pozostaje funkcjonowanie wymiaru sprawiedliwości, a dokładnie rzecz ujmując - wprowadzenie w życie dostosowanego do norm europejskich ustawodawstwa. Zagrzeb musi także stawić czoła powszechnej korupcji oraz, w szerszej skali, nadmiernemu upolitycznieniu administracji publicznej.

Chorwacja jest niewielka gospodarka na średnim poziomie rozwoju. Jej PKB wyniósł w 2010 r. 45,5 mln euro. PKB per capita Chorwacji jest wyższy niż kilku państw członków UE (Rumunii, Bułgarii, Litwy i Łotwy) i wynosi

${ }^{5}$ Partie centrowe: Chorwacka Partia Ludowa - Liberalni Demokraci (Hrvatska narodna stranka - Liberalni demokrati, HNS-LD), Chorwacka Partia Chłopska (Hrvatska seljačka stranka, HSS); prawicowa Chorwacka Partia Prawa (Hrvatska stranka prava, HSP); lewicowe: Chorwacka Partia Emerytów (Hrvatska stranka umirovljenika, HSU), Chorwaccy Socjaldemokraci (Hrvatski socijaldemokrati), Chorwaccy Laburzyści Partia Pracy (Hrvatski laburisti - Stranka rada, HL-SR); regionalne: Chorwacki Demokratyczny Związek Slawonii i Baranii (Hrvatski demokratski savez Slavonije i Baranje, HDSSB), Demokratyczne Zgromadzenie Istrii (Istarski demokratski sabor, IDS); reprezentujące mniejszości etniczne: Niezależna Demokratyczna Partia Serbska (Samostalna demokratska srpska stranka, SDSS), Partia Akcji Demokratycznej Chorwacji [Boszniacy] (Stranka demokratske akcije Hrvatske, SDAH).

${ }^{6}$ Zobacz Załącznik nr 4. Chorwaccy przywódcy w latach 1991-2011. 
17,8 tys. dolarów. W 2008 r. był on równy $65 \%$ średniej unijnej. Gospodarka opiera się przede wszystkim na sektorze usług, którego udział w PKB wynosi $68,8 \%$. Niewielki jest udział przemysłu - 19\% PKB i rolnictwa - 5,5\% PKB, coraz większe znaczenie ma także sektor budowlany, który tworzy $6,7 \%$ PKB.

Do 2008 r. Chorwacja rozwijała się w średnim tempie ok. 4,7\% PKB rocznie. Państwo przyciagnęło także największą liczbę inwestycji wśród państw Bałkanów Zachodnich - w 2008 r. 19 mld euro. Jednak globalny kryzys gospodarczy miał bardzo negatywny wpływ na krajową ekonomię. Znacznie spadł PKB - o 5,8\% w 2009 r. i o 1,5\% w 2010 r. Zagraniczne inwestycje, które dotychczas stymulowały wzrost również się obniżyły - o $11,8 \%$ w 2009 r. i 9,3\% w 2010 r. Spowodowało to trudności w utrzymaniu stabilności budżetowej i wzrost deficytu budżetowego - 3,9\% w 2009 i 6,5\% w 2010 r. Znacznie wzrosło także bezrobocie, które w 2010 r. osiagnęło poziom 18,8\%, co przełożyło się na spadek popytu wewnętrznego i spowodowało długotrwałą stagnację. Trzeba jednak zaznaczyć, że Chorwacji udało się przetrwać kryzys bez sięgania po pomoc zewnętrzną Międzynarodowego Funduszu Walutowego czy Unii Europejskiej.

Głównym problemem chorwackiej gospodarki jest wysokie uzależnienie od tzw. sektorów wrażliwych (tzn. turystyki, która odpowiada za ok. 20\% PKB) oraz niski poziom uprzemysłowienia, co przekłada się na niewielki wolumen eksportu i wysoki deficyt w handlu zagranicznym. Bardzo wysoki jest także poziom zadłużenia zagranicznego, który wynosi ponad 101\% PKB. Ze względu na wysokie koszty pracy i niską efektywność gospodarka Chorwacji jest także mało konkurencyjna $\mathrm{w}$ porównaniu np. z państwami Europy Środkowej. Rząd chorwacki ma nadzieję, że uzyskanie członkostwa w UE pozwoli na zwiększenie inwestycji zagranicznych i przyśpieszenie wzrostu gospodarczego. Wydaje się jednak, że konieczne będzie także 
przeprowadzenie strukturalnych reform, które poprawia konkurencyjność gospodarki. Pod względem rozwoju gospodarczego i wewnętrznych realiów politycznych Chorwacja znajduje się więc na dobrej drodze do zakończenia reform wewnętrznych i stopniowego wzmacniania swojej pozycji międzynarodowej, ale proces ten wymaga dalszego wysił$\mathrm{ku}$, a sukces nie jest przesądzony. 


\section{Rozdział II \\ Chorwacka droga do Unii Europejskiej}

Akcesja Chorwacji do Unii Europejskiej, której chronologiczny przebieg przedstawiono w załączniku 1 , ujęta została w ramy powołanego w 1999 r. Procesu Stabilizacji i Stowarzyszenia (Stabilization and Association Process, SAP), instrumentu przeznaczonego dla wszystkich państw Bałkanów Zachodnich. Zakładał on stopniową integrację poszczególnych krajów regionu aspirujących do członkostwa w UE poprzez szeroką i jednocześnie głęboką współprace oraz wsparcie szeregu reform o charakterze gospodarczym, politycznym i społecznym ${ }^{1}$.

W opinii Komisji Europejskiej w sprawie wniosku Chorwacji o przystapienie do Unii Europejskiej czytamy: „Rada Europejska na posiedzeniu w Kopenhadze w czerwcu 1993 r. określiła warunki kwalifikacji, które regulują proces przystapienia i przeprowadzane przez Komisję regularne oceny gotowości Chorwacji do członkostwa. Kryteria polityczne wymagały od Chorwacji zapewnienia stabilności

${ }^{1}$ Więcej na temat Procesu Stabilizacji i Stowarzyszenia na stronie Komisji Europejskiej: http://ec.europa.eu/enlargement/enlargement_process/accession_process/how_does_a_country_join_the_eu/sap/ index_pl.htm. Zobacz także: B. Górka-Winter, Polityka zewnętrzna UE wobec Batkanów Zachodnich - wniosek Chorwacji o przystapienie do UE, „Biuletyn PISM”, nr 36 (140), 16 VI 2003; Batkany Zachodnie a integracja europejska. Perspektywy i implikacje, [red. J. Muś, R. Sadowski], Urząd Komitetu Integracji Europejskiej, Ośrodek Studiów Wschodnich, Warszawa 2008. 
instytucji będących gwarantem demokracji, praworządności, respektowania praw człowieka oraz poszanowania i ochrony praw mniejszości; wymagania te sa obecnie zawarte w Traktacie o Unii Europejskiej i w Karcie Praw Podstawowych Unii Europejskiej. Kryteria gospodarcze wymagaja istnienia sprawnej gospodarki rynkowej, jak również zdolności przeciwstawiania się presji konkurencji i siłom rynkowym działajacym wewnątrz Unii. Kryterium zgodności z dorobkiem prawnym odnosi się do zdolności do przyjęcia na siebie obowiązków członkostwa wynikających z Traktatów i prawodawstwa Unii oraz z unijnego dorobku prawnego, szczególnie zaś realizacji celów unii politycznej, gospodarczej i walutowej. Zdolność Unii do przyjmowania nowych członków przy jednoczesnym utrzymaniu tempa integracji europejskiej jest istotnym czynnikiem, który należy uwzględnić w ogólnym interesie zarówno Unii, jak i krajów kandydujących"2.

Kolejnym ważnym krokiem było wystapienie Chorwacji w lutym 2003 r. z wnioskiem o członkostwo w Unii Europejskiej. Wniosek ten został pozytywnie rozpatrzony przez Komisję Europejską dopiero wiosną 2004 r., a w czerwcu tegoż roku Chorwacja uzyskała status państwa-kandydata.

Rozpoczęty w październiku 2005 r. proces negocjacji napotkał dwa znaczące wyzwania. Były to stosunki dobrosasiedzkie z pozostałymi byłymi republikami jugosłowiańskimi oraz kwestia współpracy z Międzynarodowym Trybunałem Karnym dla byłej Jugosławii (International Criminal Tribunal for the former Yugoslavia, ICTY).

Ze względu na krwawy i gwałtowny przebieg rozpadu Jugosławii Unia Europejska zwracała szczególną uwagę na

${ }^{2}$ Opinia Komisji w sprawie wniosku Republiki Chorwacji o przystapienie do Unii Europejskiej, Komisja Europejska, Bruksela 12 X 2011, KOM(2011) 667, http://ec.europa.eu/enlargement/pdf/key_documents/2011/package/hr_opinion_2011_pl.pdf. 
stabilizację sytuacji w regionie Bałkanów Zachodnich. Dla członkostwa Chorwacji w Unii Europejskiej kluczowe było utrzymywanie poprawnych stosunków z Serbią. W 1991 r. doszło do otwartego konfliktu pomiędzy obydwiema republikami i do całkowitego zerwania oficjalnych relacji dwustronnych. Jednak już w 1994 r. podpisano porozumienie o normalizacji wzajemnych stosunków. Od tego czasu stosunki serbsko-chorwackie układały się coraz lepiej. Pomogły im także przemiany polityczne, jakie zaszły w obu krajach w czasie pierwszych lat XXI w. Śmierć Franjo Tuđmana oraz odsunięcie od władzy Slobodana Miloševicia pomogło w zbliżeniu obu sasiadów. W 2004 r. podpisano umowę o ochronie mniejszości narodowych, a w 2009 r. serię umów umożliwiających zwalczanie przestępczości zorganizowanej czy rozszerzanie współpracy gospodarczej. W 2010 r. uzgodniono porozumienie o nasileniu współpracy w sprawach wojskowych. Zadra w stosunkach chorwacko-serbskich pozostaje niewatpliwie sprawa wniesionych przed Międzynarodowy Trybunał Sprawiedliwości wzajemnych pozwów o odpowiedzialność za zbrodnie przeciwko ludności cywilnej popełnione w procesie rozpadu Jugosławii.

Nieco inaczej przedstawiały się stosunki pomiędzy Bośnią i Hercegowiną a Chorwacja. Głównym powodem takiego stanu rzeczy był nieprzychylny stosunek pierwszego prezydenta Chorwacji Franjo Tuđmana do sasiedniej republiki. Od czasu przemian demokratycznych w Chorwacji relacje bośniacko-chorwackie wyraźnie się poprawiły. Podpisano szereg porozumień dotyczacych współpracy w sprawach karnych, a wybrany w 2010 r. prezydent Chorwacji Ivo Josipović wykonał wiele gestów zmierzających ku wzajemnemu wybaczeniu krzywd doznanych w czasie wojny w Bośni oraz w Chorwacji i pojednaniu pomiędzy narodami w nich uczestniczącymi.

Chorwacja jest także członkiem wielu regionalnych inicjatyw wielostronnych, takich jak Proces Współpracy Europy Południowo-Wschodniej, Porozumienie Środkowo- 
europejskie o Wolnym Handlu czy Rada Współpracy Regionalnej. Ponadto, politycy chorwaccy spotykają się z przywódcami Bośni i Hercegowiny, Czarnogóry i Serbii coraz częściej, także poza ramami istniejących instytucji ${ }^{3}$.

Tymczasem w 2008 r. doszło do eskalacji sporu pomiędzy Słowenią a Chorwacją o Zatokę Pirańska. W efekcie Lublana zablokowała otwarcie kolejnego rozdziału negocjacyjnego - Wolność, Sprawiedliwość i Bezpieczeństwo, a następnie kilku kolejnych, uzależniając dalszy postęp w negocjacjach akcesyjnych Chorwacji od uregulowania kwestii wód terytorialnych w Zatoce Pirańskiej. Istniejący wówczas status quo oznaczał dla statków słoweńskich konieczność przepływania przez wody terytorialne Chorwacji bądź Włoch, jeśli chciały wydostać się one na morze otwarte. Słowenia domagała się takiego rozwiązania, które otworzyłoby jej dostęp do wód międzynarodowych. Istotę konfliktu dobrze wyjaśnia ekspert Polskiego Instytutu Spraw Międzynarodowych, który uważa, że: „Prowadzące spór kraje odwoływały się do różnych interpretacji Konwencji ONZ o Prawie Morza. Chorwacja przywołuje tę jej część, która nakazuje przebieg granicy morskiej wzdłuż tzw. linii środkowej. W oparciu o tę zasadę określono np. granicę morską Chorwacji z Bośnią i Hercegowiną oraz z Czarnogóra. Słowenia wskazuje na argumenty historyczne oraz tę część Konwencji, która dotyczy państw o niekorzystnym położeniu geograficznym"4.

Słoweńskie stanowisko doprowadziło do zablokowania procesu negocjacji w grudniu 2008 r. i do dwukrotnego odłożenia międzyrządowej konferencji poświęconej negocjacjom akcesyjnym w czasie przychylnej rozszerzeniu prezydencji

${ }^{3}$ Owocem jednego z takich szczytów była przyjęta w $2005 \mathrm{r}$. Deklaracja Sarajewska, dotycząca współpracy w kwestii rozwiązania problemu uchodźców.

${ }^{4}$ T. Żornaczuk, Chorwacko-stoweński spór graniczny a negocjacje akcesyjne Chorwacji z UE, „Biuletyn PISM”, nr 28 (560), 22 V 2009. 
Czech w Radzie UE w pierwszej połowie 2009 r. Chorwacka droga do Unii została odblokowana wraz z podpisaniem 4 listopada 2009 r. porozumienia chorwacko-słoweńskiego. Zakładało ono oddanie sprawy w ręce międzynarodowego trybunału arbitrażowego ${ }^{5}$, co oba kraje uczyniły dnia 25 maja 2011 r. ${ }^{6}$

Oddzielny problem stanowiła współpraca Chorwacji z Międzynarodowym Trybunałem Karnym dla byłej Jugosławii. Kooperacja poszczególnych byłych republik jugosłowiańskich z Trybunałem miała stanowić swoiste rozliczenie się z okresem wojny, która przetoczyła się przez obszar Bałkanów w latach 90. Dlatego też Chorwacja była zobligowana do wydania osób oskarżonych o zbrodnie popełnione w czasie konfliktu zbrojnego oraz o dalsza pomoc, np. przy przesyłaniu dokumentów. Współpraca Chorwacji z ICTY przebiegała właściwie sprawnie poza sprawa generała Ante Gotoviny, oskarżonego o dokonanie zbrodni wojennych i zbrodni przeciwko ludzkości, co w społeczeństwie chorwackim wywoływało wiele kontrowersji.

W marcu 2005 r. Unia Europejska zawiesiła rozpoczęcie negocjacji akcesyjnych z Chorwacją na czas nieokreślony. Powołano wówczas specjalna grupę zadaniowa, mająca za zadanie ocenę współpracy Chorwacji z ICTY.

Po przyjęciu przez władze w Zagrzebiu Planu Działania, majacego na celu znalezienie Ante Gotoviny, prokurator ICTY Carla del Ponte oceniła współpracę Zagrzebia z Haga jako „pełną”, co umożliwiło rozpoczęcie tego samego dnia

${ }^{5}$ S. Hooper, Croatia, Slovenia sign border dispute deal, 4 XI 2009, http://edition.cnn.com/2009/WORLD/europe/11/04/croatia.slovenia. agreement/index.html.

${ }^{6}$ Slovene-Croatian Border Arbitration Deal Registered with UN, 26 V 2011, http://www.ukom.gov.si/en/media_room/newsletter_slovenia_ news/news/article/393/2695/48f5c149c6/?tx_ttnews[newsletter]=109. O konflikcie Chorwacji ze Słowenią zobacz także: M. Kaczorowski, Spór chorwacko-stoweński o Zatokę Pirańska, „Polski Przegląd Dyplomatyczny" 2009, nr 4-5 (50-51), s. 135-150. 
negocjacji akcesyjnych. Od momentu schwytania Gotoviny na Wyspach Kanaryjskich w grudniu 2005 r., współpraca z Trybunałem ogranicza się praktycznie do transferu dokumentów. Zarówno Unia, jak i ICTY miały w tej kwestii wiele zastrzeżeń, nie należy jednakże oczekiwać, żeby mogło to negatywnie odbić się na akcesji Chorwacji do Unii. Można uznać, że kwestia współpracy z Międzynarodowym Trybunałem Karnym dla byłej Jugosławii, a następnie eskalacja sporu ze Słowenią opóźniły przystapienie Chorwacji do Unii Europejskiej o mniej więcej 2 lata.

W trakcie samych negocjacji akcesyjnych największe trudności odnotowano w rozdziałach: 8 - polityka ochrony konkurencji, 11 - rolnictwo i polityka rozwoju obszarów wiejskich, 13 - rybołówstwo, 23 - sądownictwo i prawa podstawowe.

W zakresie polityki ochrony konkurencji głównym problemem chorwackiego rządu była restrukturyzacja przemysłu stoczniowego i hutnictwa, które utrzymywano dzięki znaczacej pomocy publicznej. Stocznie w Chorwacji zapewniaja znaczną liczbę miejsc pracy (12 tys. osób zatrudnionych w samych stoczniach i dalsze 35 tys. w przedsiębiorstwach powiazanych) i wytwarzaja 15\% chorwackiego eksportu. Z tego względu rząd w Zagrzebiu długo odkładał decyzję o prywatyzacji owego sektora, która wiązałaby się z utratą dużej części miejsc pracy w stoczniach, a także prawdopodobnie z ich częściowym zamknięciem. W latach 2009-2011, w obliczu finalizacji negocjacji oraz bezkompromisowego stanowiska UE, która domagała się zaprzestania przekazywania pomocy publicznej stoczniom, przedsiębiorstwa z tego sektora próbowano kilkakrotnie bezskutecznie sprywatyzować. Obecne plany restrukturyzacyjne zostały zaakceptowane przez Komisję Europejska oraz przez Chorwacką Agencję Ochrony Konkurencji, jednak do dnia dzisiejszego proces prywatyzacji nie wkroczył w decydujaca fazę. Traktat Akcesyjny zawiera także dwa odrębne protokoły odnoszące się do planów restrukturyzacji przemysłu 
stoczniowego i hutniczego oraz ich monitoringu przez Komisję.

W obszarze rolnictwa Chorwacja wystapiła o rekordową liczbę (29) wyłączeń i okresów dostosowawczych. W tej dziedzinie rząd zajął bezkompromisowe stanowisko, gdyż rolnicy to tradycyjny elektorat pozostajacej u władzy HDZ, często niechętny UE. Podobny problem występował w negocjacjach w zakresie rybołówstwa.

Chorwacja napotkała także poważne kłopoty z przeprowadzeniem reform w obszarach, których dotyczy rozdział 23. Obejmuje on kwestie związane z wymiarem sprawiedliwości, walkę z korupcja, prawa podstawowe oraz prawa obywateli UE. Największym wyzwaniem było przeprowadzenie kompleksowych reform, które stworza podstawy niezależnego, bezstronnego, profesjonalnego i efektywnego wymiaru sprawiedliwości. Kwestiami priorytetowymi stało się stworzenie nowego systemu rekrutacji i awansu sędziów, racjonalizacja podziału pracy i zwiększenie efektywności sądów, co miało doprowadzić do skrócenia czasu rozpatrywania spraw. Problematyczna była także efektywna walka z korupcją. UE zwracała uwage na brak woli politycznej w tym zakresie na najwyższym szczeblu, brak przejrzystości w dysponowaniu publicznymi pieniędzmi, brak wyspecjalizowanych jednostek policji i prokuratury zwalczajacych ten proceder, brak rozwiązań prawnych, które ułatwiłyby walkę z korupcją (np. prawa o konfiskacie majątku zdobytego w nielegalny sposób). W zakresie praw podstawowych głównym problemem były kwestie mniejszości i zakresu ich ochrony, w tym powrotu uchodźców i zagwarantowania przestrzegania ich praw. Rząd chorwacki podją kompleksowe działania na rzecz harmonizacji prawodawstwa $\mathrm{z}$ normami unijnymi. W 2008 r. przyjęto Strategię Reformy Wymiaru Sprawiedliwości, Strategię Antykorupcyjna, Plan Działań na rzecz Implementacji Konstytucyjnych Praw Mniejszości i rozpoczęto ich realizację. Osiagnięto 
sukcesy w walce z korupcją oraz poprawiono efektywność sądów, które w dalszym ciagu sa jednak zbyt podatne na wpływy polityczne. Zmiana władzy i rezygnacja ze stanowiska długoletniego premiera Ivo Sanadera w 2009 r. umożliwiła podjęcie bardziej zdecydowanej walki z korupcją na najwyższym szczeblu, choć można wyrazić obawę, czy nie będzie to odosobniony wypadek. Ze względu jednak na kompleksowy charakter reform trudno w takim zakresie wprowadzić zmiany w tak krótkim czasie. Dlatego na rzeczywiste efekty podejmowanych działań trzeba będzie jeszcze poczekać. Uwzględniła to także UE, która postanowiła monitorować implementację reform w tej dziedzinie do czasu uzyskania przez Chorwację pełnego członkostwa.

Komisja Europejska zgłosiła także wątpliwości co do jakości administracji państwowej w Chorwacji. Dla UE ma to zasadnicze znaczenie ze względu na możliwości wdrażania i stosowania prawa unijnego oraz wypełniania zobowiązań państwa członkowskiego. Bruksela wskazuje na znaczny przerost zatrudnienia, niekompetencję, rozbudowaną i rozdrobnioną strukturę chorwackiej administracji centralnej i samorządowej.

Negocjacje Chorwacji z Unią Europejska utrudnione były dodatkowo przez dwa inne czynniki. Jednym z nich było nastawienie Chorwatów do UE, a drugim stosunek państw członkowskich Unii do jej dalszego rozszerzenia.

Poparcie społeczne dla przystapienia Chorwacji do Unii Europejskiej wahało się - generalnie jednak zauważalna była tendencja spadkowa. Pomiędzy 2006 a 2008 r., a więc w momencie prowadzenia negocjacji, odsetek ludności uważającej członkostwo w UE za rzecz dobrą spadł z 35 do 29. Większe poparcie dla integracji Chorwacji z Unia deklarowali mieszkańcy miast (35\%) oraz absolwenci szkół wyższych (51\%), podczas gdy mieszkańcy obszarów wiejskich prezentowali zdecydowanie bardziej eurosceptyczne nastawienie, z poparciem ledwo przekraczajacym 20\%. Co więcej, we wschodniej Slawonii prawie 60\% mieszkańców 
stwierdziło, że jest źle lub zupełnie niepoinformowanych o procesie integracji europejskiej ${ }^{7}$.

W latach 2006-2009 odsetek osób, które wierzyły, że Komisja Europejska pragnie widzieć Chorwację w UE, spadł z 55 do 43. Przeprowadzone w 2009 r. badania wskazywały także, że Chorwaci zauważali poważne zagrożenia płynące z członkostwa w zjednoczonej Europie. Na przykład 51\% sądziło, że członkostwo wpłynie negatywnie na ich poczucie tożsamości narodowej, 46\% obawiało się pogorszenia swojej sytuacji finansowej, dla 44\% Chorwatów integracja z Unia oznaczała osłabienie konkurencyjności państwa oraz spadek dobrobytu. Co piaty Chorwat postrzegał członkostwo w UE jako zagrożenie dla zasad demokratycznych, a co trzeci dla swojej wolności osobistej. Jedna czwarta obywateli obawiała się także wzrostu podatków i obniżenia poziomu bezpieczeństwa ${ }^{8}$. Władze chorwackie musiały w takiej sytuacji odpowiedzieć na te pytania i obawy.

Badania przeprowadzone w 2010 r. wykazały, że już ponad 50\% mieszkańców Chorwacji uznawało się za dobrze poinformowanych o Unii Europejskiej. Z drugiej jednak strony te same sondaże wskazywały, że tylko 25\% Chorwatów uważało członkostwo w UE za dobre rozwiązanie, $32 \%$ było zaś przeciwnego zdania. Odpowiednio 38,4\% Chorwatów sądziło, że ich kraj powinien przystapić do Unii, a $42 \%$ było temu przeciwnych. Ponad $35 \%$ Chorwatów uważało w 2010 r., że na integracji europejskiej skorzystaja te osoby, którym obecnie i tak się już powodzi, podczas gdy zbliżony odsetek przypuszczał, że na akcesji skorzystaja wszyscy $(24 \%)$ lub nikt $(23 \%)^{9}$.

${ }^{7}$ Perceptions of the EU in the Western Balkans, Gallup Balkan Monitor 2009, s. 6-7, http://www.balkan-monitor.eu/files/Gallup_ Balkan_Monitor-Focus_On_EU_Perceptions.pdf.

${ }^{8}$ Tamże.

${ }^{9}$ Dane dostępne na stronie internetowej Gallup Balkan Monitor: http://www.balkan-monitor.eu/index.php/dashboard. 
Z przeprowadzonych badań wynika, że pomimo stosunkowo negatywnego nastawienia Chorwatów do procesu akcesyjnego, byli oni świadomi oczekujących wyzwań i konieczności przeprowadzania reform. Ponad $80 \%$ badanych podkreśliło wagę przyjmowania odpowiedniego prawodawstwa, zgodnego z wymogami UE. Ponad dwie trzecie było podobnego zdania na temat konieczności współpracy z ICTY. Prawie 80\% było świadomych potrzeby zakończenia sporów sąsiedzkich ${ }^{10}$. Zgodnie z wynikami badań z lipca 2011 r., 60\% Chorwatów głosujących w referendum akcesyjnym opowiedziałoby się za wejściem Chorwacji do Unii, podczas gdy $31 \%$ byłoby temu przeciwnych ${ }^{11}$.

Prowadzenie negocjacji akcesyjnych przy tak złożonym nastawieniu społecznym wymagało przyjęcia określonej strategii działań i komunikacji ze społeczeństwem. Doskonałym przykładem jest postawa w 2011 r. rządzącej wówczas HDZ wobec wyroku skazującego Ante Gotovinę za zbrodnie popełnione w czasie wojny w 1995 r. Z przeprowadzonych badań wynika, iż 95\% Chorwatów uznało ten wyrok za niesłuszny, a poparcie dla członkostwa Chorwacji w Unii spadło w kwietniu 2011 r. do zaledwie 23\%. Ówczesna premier Jadranka Kosor wielokrotnie krytykowała wyrok Trybunału, balansując przy tym na „cienkiej linie” pomiędzy poparciem wyborców w kraju a wsparciem dla chorwackich aspiracji europejskich za granica.

Oprócz eurosceptycyzmu wewnątrz kraju, władze w Zagrzebiu musiały też przekonywać zaskakujaco wielu partnerów europejskich o zasadności i potrzebie dalszego rozszerzenia Unii Europejskiej. Niechętne nastawienie większości państw zachodnich do powiększenia UE

10 Tamże.

${ }^{11}$ M. Ššstarić, From Zagreb with Love: On the Bounded Rationality of Euroskepticism and Europhilia in Croatia, http://www.balkanalysis. com/croatia/2011/09/12/from-zagreb-with-love-on-the-bounded-rationality-of-euroskepticism-and-europhilia-in-croatia/. 
o kraje bałkańskie to wynik wielu równolegle toczacych się procesów. Przede wszystkim kryzys gospodarczy i finansowy, który ogarną Europę, stanowi problem pośrednio łączony z rozszerzeniem Unii o „biedne” państwa Europy Środkowo-Wschodniej. Kryzys ten spowodował, że państwa członkowskie UE sa dużo bardziej skłonne koncentrować się na wewnętrznych problemach, a mniej chętne do pomocy innym. Co więcej, w Europie, szczególnie zachodniej, toczy się dyskusja nad masowymi migracjami, a wizja kolejnej „bałkańskiej fali” emigrantów działa zniechęcająco na polityków, którzy chcieliby podjąć próby prowadzenia polityki przychylnej rozszerzeniu. Oczywiście argumenty te nie znajduja potwierdzenia w rzeczywistości. Chorwacja jest państwem małym i stosunkowo dobrze rozwiniętym gospodarczo. Akcesja tego kraju nie wywrze na Unię dużego wpływu, nie spowoduje nadzwyczajnych wydatków ani potrzeby stawiania czoła nagłemu napływowi emigrantów zarobkowych.

Proces rozszerzenia często stawał się ofiara polityki wewnętrznej poszczególnych państw członkowskich UE. Czasem, jak w przypadku Słowenii, chodziło o wykorzystanie negocjacji akcesyjnych do osiagnięcia przewagi w sporze z Zagrzebiem ${ }^{12}$. Państwo kandydujące, jakim jest Chorwacja, stawało się jednak wielokrotnie ofiara wewnętrznej gry politycznej, często zorientowanej na przedstawianie przywódców państw członkowskich jako stanowczo przestrzegających unijnej spójności i przyjętych reguł gry. I tak np. Londyn, Haga, Sztokholm czy Berlin moga w ten sposób pokazać własnym wyborcom troskę i walkę o ochronę interesów lokalnych, pomijając przy tym fakt, że Chorwacja nie stanowiła i nie stanowi dla nich zagrożenia.

Faktem pozostaje także, że z różnych powodów społeczeństwa, ale także często i rządy niektórych państw i Grecji.

${ }^{12}$ Podobnie rzecz się ma np. w odniesieniu do sporu Macedonii 
przykładają mniejszą lub większą wagę do poszczególnych problemów. I tak np. Wielka Brytania, Finlandia i Belgia długo blokowały otwarcie negocjacji dotyczaccych wymiaru sprawiedliwości, argumentując to negatywnymi raportami na temat współpracy Zagrzebia z międzynarodowym wymiarem sprawiedliwości, walki z korupcją i przestępczością zorganizowana.

To, w jaki sposób zachowywały się poszczególne państwa, było więc złożoną i nie do końca klarowna, a często wewnętrznie sprzeczną wypadkową nastrojów społecznych, wewnętrznej gry politycznej oraz rzeczywistych interesów państwa. W tym miejscu należy jeszcze dodać, że poza wyjątkiem słoweńskim, wszystkie nowe państwa członkowskie Unii Europejskiej, włączając w to Bułgarię i Rumunię, stały konsekwentnie na stanowisku poparcia dla europejskich aspiracji Chorwacji.

Właściwe negocjacje zakończyły się 30 czerwca 2011 r. Ostatnimi zamkniętymi rozdziałami były: rybołówstwo (rozdział 13), polityka konkurencji (rozdział 8), sądownictwo i prawa podstawowe (rozdział 23), finanse i budżet (rozdział 33) oraz inne kwestie (rozdział 35). Projekt Traktatu Akcesyjnego, nakreślającego sylwetkę Chorwacji jako członka Unii Europejskiej, został doręczony premier Jadrance Kosor przez szefa polskiego rząu Donalda Tuska w dniu 17 września 2011 r. Polityka rozszerzenia Unii Europejskiej stała się, paradoksalnie, sukcesem polskiej prezydencji w UE. Paradoksalnie, gdyż poza konsekwentnym poparciem dla rozszerzenia Unii na południowy wschód, Polska nie była aktywnie zaangażowana w proces wspierania reform w tej części Europy. Państwa takie, jak Węgry, Czechy, Słowacja, Słowenia, Rumunia i Bułgaria, Austria, Niemcy, Francja czy Włochy wykazały o wiele większe zainteresowanie bądź włożyły nieporównywalnie więcej wysiłku w proces rozszerzenia niż Polska. Nie zmieniło to faktu, że właśnie na czas polskiej prezydencji w UE przypadł moment podpisania traktatu akcesyjnego przez 
Chorwację. To, jak mocna będzie pozycja państwa chorwackiego w zjednoczonej Europie, nie zależy jednak tylko od postanowień traktatowych, ale także od innych czynników.

Komisja Europejska jest zdania, że „Chorwacja osiągnęła wysoki poziom gotowości do członkostwa”. Komisja podkreślała także potrzebę „nieustawania w wysiłkach na rzecz dostosowania ustawodawstwa do unijnego dorobku prawnego oraz dalszego wzmacniania swojego potencjału administracyjnego, między innymi poprzez stałe postępy reformy administracji publicznej”. Ostrzegła też, że „będzie w dalszym ciagu uważnie śledzić wypełnianie przez Chorwację wszystkich zobowiązań podjętych w toku negocjacji akcesyjnych [...]. Monitorowanie skupi się w szczególności na zobowiązaniach podjętych przez Chorwację w dziedzinie sądownictwa, walki z korupcja, praw podstawowych, w dziedzinie sprawiedliwości, wolności i bezpieczeństwa, w tym zarządzania granicami, jak również w dziedzinie polityki konkurencji. Jeżeli w procesie monitorowania pewne kwestie wzbudzą niepokój i nie zostaną naprawione przez Chorwację, w stosownych przypadkach Komisja prześle władzom chorwackim pisma zawierajace wczesne ostrzeżenia i może zaproponować Radzie podjęcie odpowiednich środków jeszcze przed przystapieniem. Komisja zastrzega sobie również prawo do powoływania się na różne klauzule ochronne przewidziane $\mathrm{w}$ traktacie o przystapieniu, jak również na szczególne mechanizmy dotyczące pomocy państwa na rzecz chorwackiego przemysłu stoczniowego i stalowego" ${ }^{13}$. To bardzo ważna i wyraźna wiadomość zarówno dla Chorwacji, jak i państw Unii Europejskiej. Do momentu zakończenia reform Komisja Europejska będzie przyglądać się pracom chorwackiego rządu i parlamentu. Jeśli ocena będzie negatywna, Komisja przedsięweźmie odpowiednie kroki. To realne zagrożenie dla akcesji Chorwacji do UE. Pamiętać bowiem należy, że traktat akcesyjny musi

${ }^{13}$ Opinia Komisji w sprawie wniosku Republiki Chorwacji... 
zostać ratyfikowany przez wszystkie państwa członkowskie UE, a z nieoficjalnych rozmów z przedstawicielami niektórych z nich wynika, że część krajów zachodnioeuropejskich może, choć nie musi, mieć z tym poważny problem. Oznacza to, że jeśli rząd chorwacki zaprzestanie reform, to instrumenty kontroli i monitoringu zaaplikowane Rumunii i Bułgarii nie będa potrzebne - Chorwacja bowiem do Unii nie przystapi lub przystapi z dużym opóźnieniem. 
Rozdział III

\section{Chorwacja w Unii Europejskiej}

\section{Aspekty instytucjonalne}

Po przystapieniu Chorwacji do Unii Europejskiej państwo to uzyska określoną liczbę głosów w Radzie UE i Radzie Europejskiej, miejsc w Parlamencie Europejskim, a także prawo wysłania swoich przedstawicieli do innych instytucji europejskich. Dzięki temu kraj ten będzie mógł reprezentować swoje stanowisko i interesy, a także wpływać na proces decyzyjny Unii Europejskiej.

Chorwacja powiększy do 12 grupę państw małych, których liczba mieszkańców nie przekracza $5,5 \mathrm{mln}$. Kolejne 8 państw zamieszkanych jest przez ludność licząca od 5,5 do $12 \mathrm{mln}$. Holandia i Rumunia, jako kraje średnie, mają odpowiednio 16,5 i $21 \mathrm{mln}$ mieszkańców. Natomiast tzw. duża szóstka: to Polska (38 mln), Hiszpania (47 mln), Włochy (60 $\mathrm{mln})$, Wielka Brytania (62 mln), Francja (64 mln) i Niemcy (81 mln).

Przystępując do UE Chorwacja będzie musiała zmierzyć się z kilkoma problemami związanymi z przestawieniem polityki państwowej na poziom europejski. Po pierwsze, nie będzie miała tego samego wpływu i oddziaływania politycznego, które mają duże państwa członkowskie, aby móc efektywnie kształtować politykę Unii. Po drugie, w związku ze stosunkowo niskim PKB i niską liczba populacji, środki administracyjne czy finansowe, potrzebne 
do budowania strategii lub planów politycznych, będą dużo słabsze niż w przypadku państw bogatych czy większych. Po trzecie, Chorwacja stając się nowym członkiem UE, nie będzie cieszyć się bliskimi, zinstytucjonalizowanymi kontaktami z urzędami unijnymi, przede wszystkim z Komisja Europejską. Pozbawiona też będzie w znacznym stopniu praktycznej wiedzy, jak kształtować można politykę europejską w sposób „pozalegislacyjny”. Polska potrzebowała kilku lat, aby efektywnie przygotować, przedstawić i zagwarantować sobie przyjęcie propozycji legislacyjnej - kilku lat potrzebować będzie najpewniej i Zagrzeb.

Obecny proces podejmowania decyzji w UE, jak i obowiazujący system instytucjonalny, mieszają elementy federalne czy wspólnotowe z międzyrządowymi. Trwająca dyskusja na temat przyszłego kształtu UE także oscyluje wokół osi, która wzmacnia bądź to elementy wspólnotowe, bądź międzyrządowe. Generalnie rzecz ujmując, podejście wspólnotowe powinno zasadniczo być preferowane przez państwa małe. Wizja takich instytucji, jak silny Parlament Europejski czy Komisja, które kieruja się interesem całej Unii, a nie tylko jej najważniejszych, najbogatszych (tzn. wpłacających największe kwoty do wspólnego budżetu) i największych członków, stanowi dla państw małych, w tym oczywiście Chorwacji, zachęcającą alternatywę dla metody międzyrządowej. Ta bowiem - obecnie dominująca - skupia znaczna część władzy w rękach obydwu Rad. Dominacja państw dużych jest widoczna szczególnie w Radzie Unii Europejskiej. Z drugiej jednak strony, państwa, zwłaszcza te małe, będa starały się bronić swoich interesów samodzielnie, bez przerzucania odpowiedzialności na instytucje ponadnarodowe - kwestia legitymizacji i suwerenności na pewno wywierać

${ }^{1}$ Więcej nt. funkcjonowania małych państw w Unii Europejskiej zobacz: D. Panke, The Influence of Small States in the EU: Structural Disadvantages and Counterstrategies, DEI Working Paper 08-3, UCD Dublin European Institute, May 2008. 
będzie duży wpływ na stanowisko chorwackie wobec kształtu instytucjonalnego UE.

Dotychczasowy system polityczny Unii Europejskiej, choć zapewniający przewagę międzyrządowej metodzie sprawowania władzy, pozwala małym państwom członkowskim na przedstawienie i obronę swojego stanowiska nawet w opozycji do takich gigantów, jak Niemcy czy Francja. Zasadniczo bowiem każde państwo członkowskie ma trzy sposoby na wpływanie na szeroko pojęty proces decyzyjny UE. Sa to:

- siła głosu i możliwości przetargowe, które odpowiadają sile społeczno-gospodarczej danego kraju;

- wpływ ideologiczny, który tworzony jest przez zaplecze ekspercko-techniczne;

- wpływ instytucjonalny, oparty na uczestnictwie przedstawicieli danego państwa $\mathrm{w}$ poszczególnych instytucjach wspólnotowych, takich jak np. Komisja Europejska².

Sprawne funkcjonowanie Chorwacji na forum Unii Europejskiej zależeć będzie w największym stopniu od jej zdolności ideologicznych i instytucjonalnych. Sa to te dwa czynniki, które można stosunkowo łatwo zmodyfikować i wzmocnić. Okres 2-3 lat wydaje się osiagalny dla Chorwacji, aby przygotowała pierwsza, innowacyjna propozycję lub pozwoliła swoim przedstawicielom na zapoznanie się $\mathrm{z}$ regułami gry, panujaccymi $\mathrm{w}$ poszczególnych instytucjach unijnych. Niemożliwe jest przy tym, aby w tym samym okresie Chorwacja podwoiła np. liczbę głosów w Radzie.

Funkcjonowanie Chorwacji w UE w pierwszym okresie będzie musiało polegać na poznaniu, zrozumieniu i odpowiednim wykorzystaniu elementów procesu decyzyjnego, które nie sa bezpośrednio związane z głosowaniem w Radzie. Przedstawianie odpowiednich argumentów, umiejętność budowania koalicji czy tworzenia kompromisów moga z powodzeniem równoważyć małą liczbę głosów w tej instytucji. Ze względu na swój rozmiar oraz ograni-

${ }^{2}$ Tamże, s. 5. 
czone zasoby eksperckie i administracyjne, Chorwacja będzie także musiała ustalić listę priorytetów i po prostu ignorować kwestie, które są dla niej mało lub niewiele znaczące. Z dużym prawdopodobieństwem można założyć, że pozycja Zagrzebia zostanie wzmocniona przez zawiązanie strategicznego partnerstwa podobnego do tych, stworzonych np. przez państwa bałtyckie, kraje Beneluksu czy tandemy hiszpańsko-portugalskie lub niemiecko-francuskie. Najbardziej prawdopodobne wydają się „sojusze” z Węgrami, Austrią lub Włochami, każdy z nich potencjalnie będzie obejmować także Słowenię.

Chorwackie veto będzie także dużo skuteczniejsze i będzie można częściej odwoływać się do niego, jeśli uda się je przedstawić w czasie inicjowania procesu decyzyjnego. W tym miejscu należy wspomnieć, że małe państwa, a więc także Chorwacja, sa w pewien sposób dyskryminowane przez Komisję Europejska przy ustalaniu agendy unijnej i propozycji legislacyjnych, kiedy przede wszystkim bierze się pod uwage interes i stanowisko dużych państw i wówczas to ich stanowisko jest kluczowe w początkowej fazie procesu decyzyjnego oraz planowania.

\section{RADA EUROPEJSKA}

Chorwacja, jako członek Unii Europejskiej, będzie uczestniczyć na równych prawach w spotkaniach Rady Europejskiej, która nadaje Unii impulsy niezbędne do jej rozwoju i określa ogólne kierunki i priorytety polityczne. Rada Europejska ma także wpływ na wiele innych aspektów funkcjonowania UE, np. mianuje swojego Prezydenta, Przewodniczącego Komisji Europejskiej, Wysokiego Przedstawiciela Unii ds. Zagranicznych i Polityki Bezpieczeństwa oraz Przewodniczacego Europejskiego Banku Centralnego. Decyzje podejmowane są na podstawie konsensusu, a więc zgody wszystkich państw uczestniczacych, także Chorwacji. Państwo to będzie więc mogło, choć w stopniu ograniczonym przez 
swoja geopolityczna, demograficzną i gospodarczą pozycję, wpłynąc na te decyzje. Ze względu na przypominający polski system konstytucyjny oraz podziały polityczne, nie jest do końca pewne, kto będzie reprezentował Chorwację w Radzie Europejskiej. Najprawdopodobniej będzie to premier Chorwacji, jednak niewykluczone, że chęć taką może zgłosić także prezydent. Wiele zależy od wyniku wyborów i podziału sił pomiędzy parlamentem a pałacem prezydenckim.

\section{RADA UNII EUROPEJSKIEJ}

Przystępując do Unii Chorwacja będzie posiadała odpowiednia liczbę głosów w jej Radzie - najważniejszym prawodawczym organie UE. Ścieżka ustawodawcza jest dość złożona. Kwalifikowana większość głosów w Radzie wymaga bowiem, aby decyzja była podjęta przez:

- 67\% państw członkowskich (ale jeśli propozycja prawodawcza pochodzi od Komisji Europejskiej, to tylko przez połowę z tej liczby). Oznacza to odpowiednio: 18 i 14 państw członkowskich. Po przystapieniu Chorwacji do Unii, jedynie pierwsza z tych liczb się zmieni i wynosić będzie 19;

- 74\% głosów, czyli obecne 255 z 345 zamienione zostanie na 260 z 352 (345 obecnych plus 7 głosów chorwackich). Chorwacja, obok Danii, Irlandii, Litwy, Słowacji i Finlandii dysponować będzie 7 głosami w Radzie, czyli będzie miała więcej o 3 głosy od Łotwy czy Słowenii i o 3 głosy mniej od Austrii, Bułgarii i Szwecji. Chorwackie głosy nie będą więc same w sobie wiele znaczyły;

- $62 \%$ ludności, reprezentowanej w Radzie-obecnie jest to $311 \mathrm{mln}$ (spośród 484,2 mln). Po akcesji Chorwacji liczba ludności wzrośnie do 488,65 mln, a odsetek Chorwatów wśród pozostałych członków wyniesie $1,09 \%$. Także więc i ten parametr nie będzie dla Chorwacji oznaczał wielu możliwości znaczącego wpływu na decyzje Rady.

Od 2014 r. kwalifikowana większość głosów zostanie uproszczona do $55 \%$ państw i $65 \%$ głosów. Oznacza to, że 
od 2014 r., tzn. pół roku po przystapieniu Chorwacji do Unii Europejskiej, liczba głosów wymaganych do podjęcia decyzji w Radzie spadnie i w rezultacie zmniejszy się także wpływ państw małych. Państwa duże i średnie potrzebować będą 15 państw popierających daną propozycję.

Ponadto, nowy system głosowania zakłada konieczność uzyskania poparcia państw reprezentujących 65\% ludności, a więc więcej niż w obecnie obowiązującym systemie. Państw posiadających powyżej $12 \mathrm{mln}$ mieszkańców jest zaledwie 8 . To z kolei wpłynie dodatnio na siłę legislacyjną Chorwacji.

Wprowadzany od 2014 r. system głosowania zakłada także, że propozycja legislacyjna zostanie odrzucona, jeśli przynajmniej 4 państwa członkowskie zagłosują przeciwko niej. W praktyce więc nawet 4 małe państwa (np. Słowenia, Chorwacja, Malta i Cypr) będą w stanie zablokować proces decyzyjny. Oczywiście w przypadkach, kiedy Rada decyduje na podstawie uzyskanego consensusu, głos Chorwacji będzie miał takie samo znaczenie, jak głos Niemiec czy Francji, pamiętając jednak, że zbyt częste używanie veta stępia jego ostrze i pozbawia wiarygodności państwo wetujace. Oznacza to, że Chorwacja, należąc do grupy państw małych, chcąc wpłynąć na proces decyzyjny, będzie musiała użyć umiejętności przekonania partnerów europejskich do swoich racji. Istnieć jednak będą z pewnością specyficzne konstelacje, w których Chorwacja może odgrywać rolę ,języka u wagi” w Radzie. Ponadto zakres spraw objętych koniecznością uzyskania jednomyślności pozostawia Chorwacji dość potężny oręż w kluczowych sprawach „niegospodarczych”.

Przy istniejacym obecnie systemie głosowania w UE Chorwacja wetować będzie mogła w następujących obszarach:

- rozszerzenie Unii;

- opodatkowanie;

- finanse Unii (włączając w to sprawy budżetowe);

- harmonizacja prawodawstwa w obszarze bezpieczeństwa i opieki socjalnej; 
- niektóre kwestie związane ze Sprawiedliwością i Sprawami Wewnętrznymi (takie, jak operacyjna współpraca policji, prawo rodzinne, prokurator europejski);

- Wspólna Polityka Zagraniczna i Bezpieczeństwo (poza pewnymi wyjątkami);

- Wspólna Polityka Bezpieczeństwa i Obrony (poza pewnymi wyjątkami);

- obywatelstwo europejskie;

- niektóre zagadnienia instytucjonalne (np. system wyborczy i skład Parlamentu Europejskiego, niektóre mianowania, skład Komitetu Regionów i Komitetu Gospodarczo-Społecznego, rewizja traktatów).

Jako dodatkowe „wzmocnienie” pozycji Chorwacji na forum UE wymienić należy rotacyjną Prezydencję w Radzie, która pozwala państwu, także temu małemu, na kierowanie pracami Rady przez półroczny okres. Wattpliwe jest, aby Chorwacja objęła Prezydencję przed rokiem 2020, albowiem do końca tego roku ustalono już terminy dla innych państw członkowskich.

\section{PARLAMENT EUROPEJSKI}

Chorwacja będzie posiadała w Parlamencie Europejskim 12 europosłów (na 736 ogółem, a od 2014 r., tj. od VIII kadencji - 751) - tylu samo, co Irlandia i Litwa, o 1 mniej od Danii, Słowacji i Finlandii, a z kolei więcej od Łotwy czy Słowenii, które mają odpowiednio 8 i 7 reprezentantów w Europarlamencie. Największe partie chorwackie wzmocnią 2 największe eurofrakcje: HDZ jako członek Europejskiej Partii Ludowej, a SDP - Grupę Postępowego Sojuszu Socjalistów i Demokratów. Trudno obecnie przewidzieć, czy pozostałe, dużo mniejsze, partie chorwackie dostaną się do Parlamentu Europejskiego - być może członków przybędzie Grupie Porozumienia Liberałów i Demokratów na rzecz Europy (HNS), Europejskim Konserwatystom i Reformatorom, Europie Wolności i Demokracji (HSP) czy 
Konfederacyjnej Grupie Zjednoczonej Lewicy Europejskiej. Chorwaci będą też mogli liczyć przynajmniej na jedno stanowisko wiceprzewodniczącego w którejś z komisji parlamentarnych.

Sądząc po polskich doświadczeniach, po podpisaniu traktatu akcesyjnego chorwaccy obserwatorzy w Europarlamencie będa zapraszani do prac w komisjach parlamentarnych itp. Natomiast już po przystapieniu do Unii w lipcu 2013 r., aż do nowych wyborów, które odbędą się prawdopodobnie latem 2014 r., chorwaccy obserwatorzy, a przynajmniej 12 z nich, uzyska prawa posłów.

\section{KOMISJA EUROPEJSKA}

Chorwacja uzyska prawo do obsadzenia stanowiska jednego komisarza w Komisji Europejskiej. Ciężko jest obecnie przewidzieć, jaki obszar przekazany zostanie Chorwatom. Prawdopodobnie, w pierwszym roku członkostwa w UE, otrzymaja oni mniej znaczace stanowisko, podobnie jak Bułgarzy i Rumuni w roku 2007. Kolejny skład Komisji Europejskiej jest obecnie niemożliwy do przewidzenia.

\section{CHORWACI W POZOSTAŁYCH INSTYTUCJACH UNII EUROPEJSKIEJ}

Zgodnie z obowiąującymi w Unii Europejskiej zasadami, Prezes Chorwackiego Banku Narodowego zasiadzie w Radzie Ogólnej Europejskiego Banku Centralnego. Chorwat, prawdopodobnie minister finansów, zostanie członkiem Rady Gubernatorów Europejskiego Banku Inwestycyjnego. Chorwacja znajdzie się w jednej grupie z Polskąa, która wybiera 4 spośród 18 zastępców Rady Gubernatorów.

${ }^{3} \mathrm{~W}$ grupie tej będą także: Słowacja, Słowenia, Bułgaria, Czechy, Cypr, Węgry i Malta. 
Dwa ciała konsultacyjne: Komitet Regionów i Komitet Gospodarczo Społeczny zyskaja po 9 nowych członków z Chorwacji. Chorwaci zasiąda także w Europejskim Trybunale Obrachunkowym (1 rewident), Trybunale Sprawiedliwości Unii Europejskiej, Sądzie (wcześniej Sąd Pierwszej Instancji, obecnie organ Trybunału Sprawiedliwości UE) oraz w Sądzie do spraw Służby Publicznej (po 1 sędzim). Co więcej, obywatele Chorwacji będą mogli startować w konkursach o prace w instytucjach i agencjach unijnych.

\section{Aspekty gospodarcze i finansowe}

\section{BUDŻET UNII EUROPEJSKIEJ}

Zgodnie z dokumentem Komisji Europejskiej z 17 czerwca 2011 r., kwota, którą Chorwacja powinna dysponować w 2013 r., a więc w ostatnim półroczu obowiązującego budżetu, w ramach tzw. pakietu finansowego, wyniesie $473,4 \mathrm{mln}$ euro ${ }^{4}$. Suma ta została ustalona na podstawie doświadczeń akcesyjnych ostatnich 12 państw członkowskich, przy jednoczesnym wzięciu pod uwagę obecnie obowiązujących zasad i profilu płatności obowiązującego od początku Perspektywy Finansowej na lata 2007-2013.

Zgodnie $\mathrm{z}$ artykułem 27 projektu traktatu akcesyjnego Chorwacja ma wpłacić do Europejskiego Banku Inwestycyjnego kwotę 42,72 mln euro w 8 równych ratach rozłożonych do listopada 2018 r. Na Fundusz Badań Węgla i Stali przeznaczonych ma zostać z budżetu chorwackiego 494 tys. euro ${ }^{5}$.

${ }^{4} \mathrm{Na}$ podstawie: European Union Common Position (revision of CONF-HR 30/07). Charter 33-Financial and budgetary positions, http:// www.mvep.hr/custompages/static/hrv/files/pregovori/ZSEUEN/33.pdf; Komisja Europejska, Non-paper on the DCP for Croatia on Chapter 33 Financial and Budgetary provisions. Inidcative forecast of payments appropriations and own resources payments.

${ }^{5}$ Tamże, artykuł 28. 
Tabela 1. Propozycja Komisji Europejskiej Pakietu Finansowego dla Chorwacji w drugiej połowie 2013 r. (w mln euro)

\begin{tabular}{|l|l|}
\hline 1. Zrównoważony wzrost & $\mathbf{2 4 2 , 3}$ \\
\hline Konkurencyjność dla rozwoju i zatrudnienia & $17,6\left(23,7^{a}\right)$ \\
\hline Spójność dla rozwoju i zatrudnienia & 224,7 \\
\hline 2. Ochrona i zarządzanie zasobami naturalnymi & $\mathbf{1 4 , 3}$ \\
\hline Wydatki związane z rynkiem & 9 \\
\hline Płatności bezpośrednie & 0 \\
\hline Rezerwa na rozminowywanie & 0 \\
\hline Rozwój obszarów wiejskich & 0 \\
\hline Europejski Fundusz Rybacki & 4,4 \\
\hline Inny rodzaj wsparcia, Life + & 0,9 \\
\hline $\begin{array}{l}\text { 3. Obywatelstwo, wolność, bezpieczeństwo } \\
\text { i sprawiedliwość }\end{array}$ & $\mathbf{4 2 , 2}$ \\
\hline Wolność, bezpieczeństwo i sprawiedliwość & 1,1 \\
\hline Przystosowanie do Schengen & $40\left(80 \mathrm{w} 2014\right.$ r. $\left.^{b}\right)$ \\
\hline Obywatelstwo & 1,1 \\
\hline Fundusz Przejściowy & $0(29$ według Radyc) \\
\hline 4. EU jako aktor globalny & $\mathbf{7 7 , 6}$ \\
\hline 5. Administracja & $\mathbf{2 2}$ \\
\hline 6. Wyrównania & $\mathbf{7 5}\left(\mathbf{w} \mathbf{2 0 1 4}\right.$ r. 28,6 $\left.{ }^{d}\right)$ \\
\hline Suma środków finansowych & 473,4 \\
\hline Środki finansowe bez działu 5 (administracja) & $\mathbf{4 5 1 , 4}$ \\
\hline Środki własne & 267,7 \\
\hline Pozycja netto & 183,7 \\
\hline
\end{tabular}

Uwaga:

${ }^{a}$ European Union Common Position (revision of CONF-HR 30/07). Charter 33 - Financial and budgetary positions, http://www.mvep.hr/custompages/static/ hrv/files/pregovori/ZSEUEN/33.pdf.

${ }^{b}$ Treaty concerning the Accession of the Republic of Croatia, Council of the European Union, Brussels, 22 IX 2011 (OR. en), 14509/11, INF 162 ELARG 95, http:// register.consilium.europa.eu/pdf/en/11/st14/st14509-re01.en11.pdf, artykuł 31(2).

${ }^{c}$ Tamże, artykuł 30(4).

${ }^{d}$ Tamże, artykuł 32(2).

Źródło: Non-paper on the DCP for Croatia on Chapter 33 Financial and Budgetary provisions. Inidcative forecast of payments appropriations and own resources payments; opracowanie własne. 
Tabela 2. Wyliczenia Komisji Europejskiej przewidujące środki własne Chorwacji (w mln euro)

\begin{tabular}{|l|c|}
\hline $\begin{array}{l}\text { Tradycyjne zasoby własne (opłaty wyrównawcze od cukru } \\
\text { oraz opłaty rolne i cła) }\end{array}$ & 25,5 \\
\hline $\begin{array}{l}\text { Zasoby własne oparte na VAT (część krajowego podatku } \\
\text { VAT pobierana przez państwa członkowskie na szczeblu } \\
\text { krajowym) }\end{array}$ & 36,5 \\
\hline $\begin{array}{l}\text { Zasoby własne oparte na DNB (,składki krajowe” oparte na } \\
\text { DNB poszczególnych państw członkowskich) }\end{array}$ & 192 \\
\hline Sumy ryczałtowe & 1,5 \\
\hline Rabat Wielkiej Brytanii & 12,4 \\
\hline Suma & $\mathbf{2 6 8}$ \\
\hline
\end{tabular}

Źródło: Non-paper on the DCP for Croatia on Chapter 33 Financial and Budgetary provisions. Inidcative forecast of payments appropriations and own resources payments; opracowanie własne.

Unia Europejska ustanowiła także na 2013 r. Fundusz Przejściowy w wysokości $29 \mathrm{mln}$ euro. Zadaniem Funduszu jest rozwinięcie i wzmocnienie zdolności administracyjnych i sądowniczych Republiki Chorwacji w zakresie przystosowania do wprowadzania w życie legislacji oraz tzw. najlepszych praktyk unijnych ${ }^{6}$.

\section{WSPÓLNA POLITYKA ROLNA}

Wspólna Polityka Rolna (WPR), to jeden z najważniejszych elementów funkcjonowania zjednoczonej Europy. Oczywiście od momentu przystapienia Chorwacji do Unii, kraj ten będzie współuczestniczył w WPR. Polityka ta koncentruje się z jednej strony na dofinansowywaniu produkcji rolnej (lub jej limitowaniu), a z drugiej strony na wsparciu rozwoju obszarów wiejskich. Pomimo iż pod koniec lat 80 .

\footnotetext{
${ }^{6}$ Tamże, artykuł 30(4).
} 
wydatki na WPR pochłaniały prawie trzy czwarte budżetu UE, to udział ten znaczaco spada. Obecna perspektywa finansowa na lata 2007-2013 przyznaje 42\% środków budżetowych na WPR, z czego mniej więcej trzy czwarte przeznaczonych jest na dopłaty bezpośrednie, a pozostała część na rozwój obszarów wiejskich.

W Chorwacji dopłaty bezpośrednie będą wprowadzane stopniowo przez okres 10 lat według ustalonego harmonogramu dochodzenia do pełnego poziomu płatności, przy czym w pierwszym roku członkostwa chorwaccy rolnicy otrzymaja zaledwie $25 \%$ pełnej kwoty ${ }^{7}$. W ramach wydatków przeznaczonych na wyrównanie płac i rozwój obszarów wiejskich, $10 \mathrm{mln}$ euro rocznie zostanie przyznane na wsparcie winiarstwa chorwackiego, a w okresie 10-letnim dodatkowe 9,6 mln euro na rozminowywanie terenów dotkniętych wojna. Kwoty dopłat bezpośrednich nie zostały uwzględnione w tabeli zaprezentowanej powyżej, ponieważ dopłaty bezpośrednie wykonywane są w roku następnym (z reguły w marcu).

W ramach IPARD w 2013 r. Chorwacja ma do dyspozycji 27,7 mln euro. Phasing in, czyli stopniowe właczanie w struktury poprzez zwiększanie kwot należnych w ramach danej polityki, przewiduje, że środki budżetowe przeznaczone na rozwój obszarów wiejskich w ramach Wspólnej Polityki Rolnej będą realizowane w następujący sposób: 30\% w 2013 r., 70\% w 2014 r., 90\% w 2015 r. i pełna pula w roku 2016. W odniesieniu do rozwoju obszarów wiejskich przyjęto, że w związku z bardzo krótkim okresem planowania (6 miesięcy 2013 r.) nie jest możliwe efektywne wprowadzenie w życie narodowego planu rozwoju obszarów wiejskich. Chorwacja powinna w tym okresie

${ }^{7}$ I rok członkostwa (2013) - 25\%, II rok (2014) - 30\%, III rok (2015) $-35 \%$, IV rok $(2016)-40 \%$, V rok $(2017)-50 \%$, VI rok $(2018)-60 \%$, VII rok $(2019)-70 \%$..., X rok członkostwa $(2022)-100 \%$. 
korzystać z programu przedakcesyjnego IPARD. Jako swoistą rekompensatę, UE zaproponowała Chorwacji, aby od 2014 r. korzystała z pełnej puli przeznaczonej na rozwój obszarów wiejskich.

W czasie negocjacji Chorwacja zagwarantowała sobie wiele zwolnień i okresów przejściowych. Jeden z nich odsuwa do 2018 r. przyjęcie standardów europejskich w obszarze tzw. dobrej praktyki rolniczej oraz ekologicznych warunków produkcji rolnej. Przez 3 lata od momentu przystapienia do UE Chorwacja będzie mogła też wspierać funduszami nie wchodzącymi w skład wspólnej polityki europejskiej produkcję buraka cukrowego, niektóre rodzaje oliwy z oliwek, tytoniu, chów krów i macior. Zagrzeb będzie mógł wykorzystać rezerwę budżetową na pomoc dla najbardziej wrażliwych sektorów, jak chów rogacizny, produkcję mleka czy tytoniu.

Od momentu przystapienia do UE Chorwacja będzie miała 12 miesięcy na rejestrację produktów rolnych i żywnościowych na poziomie europejskim, które zostały już zarejestrowane w Chorwacji jako produkty lokalne, na przykład gęsty syrop jabłkowy - pekmez, różnego rodzaju owocowe brandy - tzw. rakije, czy pršut z Istrii ${ }^{8}$.

Udział państwa chorwackiego we Wspólnej Polityce Rolnej po 2013 r. stanowi sporą niewiadomą ze względu na tocząca się obecnie debatę na temat przyszłości tej polityki. Obecnie Komisja Europejska rozważa trzy alternatywne podejścia do reformy WPR:

1. Kontynuacje dotychczasowej polityki powiązana z korektą najbardziej uciążliwych niedoskonałości, m. in. podziału płatności bezpośrednich. Obecny system oznacza znaczne różnice między dopłatami do hektara w „starej” i w „nowej” Unii z największą w 2010 r. różnica pomiędzy greckim rolnikiem z 385 euro/ha i rolnikiem łotewskim

${ }^{8}$ Co ciekawe, większość z tych produktów znana i produkowana jest tradycyjnie także w pozostałych państwach regionu Bałkanów. 
z 21 euro/ha. Ten wariant oznacza dodatkowe korzyści dla tych państw członkowskich, których poziom rozwoju rolnictwa znajduje się obecnie poniżej średniej unijnej. Nie wiadomo jednak, w jakim stopniu pokrywał się on będzie z polityką klimatyczno-energetyczną UE;

2. Przekształcenie Wspólnej Polityki Rolnej w politykę zorientowaną bardziej ekologicznie, a jednocześnie bardziej sprawiedliwa, skuteczniejsza i efektywniejsza (ukierunkowana polityka dopłat wraz z jej „zazielenianiem” oraz wzmocnione ukierunkowywanie rozwoju obszarów wiejskich);

3. Praktycznie całkowite, choć stopniowe, zrezygnowanie z dopłat bezpośrednich, przy przeorientowaniu polityki na ekologiczna. I choć znajduje ona poparcie w Zjednoczonym Królestwie, Holandii, Szwecji czy Danii, to sprzeciw zarówno Parlamentu Europejskiego, jak i Rady sprawia, że ma ona raczej nikłe szanse na wprowadzenie w życie, choć będzie stanowiła niewątpliwie ważną kartę przetargowąa .

W interesie Chorwacji, podobnie zreszta jak Polski, leży utrzymanie istnienia i dotychczasowego kształtu Wspólnej Polityki Rolnej, przy jednoczesnym wyrównaniu dopłat z uwzględnieniem interesu państw nowych, rolniczo słabiej rozwiniętych od „starej” Unii. Konsekwentnie, Chorwacja poprzeć powinna także propozycję Komisji Europejskiej wprowadzajacej limit wsparcia (capping) dla dużych gospodarstw, czyli stosunkowo większe wsparcie dla gospodarstw średnich i drobnych. Komisja Europejska zapowiada wprowadzenie stopniowanego cappingu dla gospodarstw, których dochód przekroczył 150 tys. euro, przy czym kwota powyżej 300 tys. euro objęta zostanie całkowitą redukcja. Pieniądze z cappingu trafią do II filaru WPR, przeznaczonego na rozwój obszarów wiejskich, a nie na

${ }^{9}$ R. Gooch, European Commission publishes thoughts on CAP reform, 9 XII 2010, http://www.fwi.co.uk/Articles/09/12/2010/124683/ European-Commission-publishes-thoughts-on-CAP-reform.htm. 
dopłaty bezpośrednie. Pieniądze te trafią więc do kopert narodowych państw, gdzie zostały wygenerowane, a nie do unijnej puli, z której później byłyby rozdzielane. Małe gospodarstwa $\mathrm{w}$ Chorwacji nie osiagna więc z cappingu bezpośrednich korzyści. Z drugiej strony opcja ta nie jest niekorzystna dla państwa chorwackiego, w odróżnieniu np. od rolników z Wielkiej Brytanii, Niemiec czy Czech, którzy mają duże gospodarstwa. Stąd słuszne wydaje się poparcie tej opcji, jako podążanie w odpowiednim kierunku wzmacniania II filaru WPR.

\section{POLITYKA SPÓJNOŚCI}

Polityka spójności ma za zadanie zrównoważenie poziomu rozwoju gospodarczego, a więc także poziomu życia pomiędzy poszczególnymi regionami UE, poprzez podniesienie poziomu spójności gospodarczej, społecznej i przestrzennej. Dokumenty Unii Europejskiej definiują politykę spójności w sposób następujący: „Spójność gospodarcza jest mierzona za pomoca produktu krajowego brutto na mieszkańca, uwzględniając parytet siły nabywczej. [...] Spójność społeczna jest mierzona za pomoca wskaźnika stopy bezrobocia, ale coraz częściej jako miernik uwzględnia się stopę partycypacji (miernik określający, jaka część ludności w wieku produkcyjnym znajduje zatrudnienie). [...] Spójność terytorialna (przestrzenna) jest mierzona czasem przejazdu do danego obszaru komunikacją lotnicza, drogową i kolejowa. Używa się także wskaźnika ilości konsumentów osiaganych w danych czasie" 10 .

Zasadniczo głównymi beneficjentami polityki spójności sa nowe państwa członkowskie oraz niektóre regiony „starej” Unii, jak np. część Walii, Niemcy wschodnie,

${ }^{10}$ Polityka spójności Unii Europejskiej (Cohesion Policy), Portal Funduszy Europejskich, http://www.funduszeeuropejskie.gov.pl/slownik/Strony/Polityka_spojnosci_Unii_Europejskiej.aspx. 
południowe Włochy czy część Portugalii, Hiszpanii i Grecji. W 2012 r. Unia przeznaczy na politykę spójności ponad 44 mld euro, a w 2013 r. suma ta przekroczy 45 mld. W obecnym kształcie polityka spójności obejmie także na pół roku Chorwację. Podobnie, jak w przypadku Wspólnej Polityki Rolnej, nie wiadomo w jaką stronę potoczą się losy polityki spójności i w jakim kierunku będzie ona ewoluowała.

Na potrzeby polityki spójności Chorwacja podzielona została na trzy regiony na poziomie NUTS- $2^{11}$, odpowiadajace polskim województwom: Północno-zachodnia Chorwacja - Sjeverozapadna Hrvatska; Centralna i Wschodnia (Panońska) Chorwacja - Središnja i Istočna (Panonska) Hrvatska; Adriatycka Chorwacja - Jadranska Hrvatska.

Finansowanie w ramach „Spójność dla rozwoju i zatrudnienia", czyli największej finansowo części polityki spójności, podlegać będzie, podobnie jak w przypadku Wspólnej Polityki Rolnej, procesowi phasing in. I tak, w 2013 r. Chorwacja dostanie 30\% kwoty, która dostałaby jako „stare” państwo członkowskie. W 2014 r. udział ten wzrósłby do 70\%, w 2015 r. do 90\%, a w 2016 r. do 100\%. To znaczy, że kwota 449,4 mln euro na 2013 r. (podzielona na pół, gdyż Chorwacja uczestniczyć będzie jako państwo członkowskie w polityce spójności dopiero od drugiej połowy 2013 r.), będzie pomnożona przez 2,33 w 2014 r. (1,047 mld euro) i przez 3 w 2015 r. (1,348 mld euro).

${ }^{11}$ Klasyfikacja Jednostek Terytorialnych do Celów Statystycznych (Nomenclature of Territorial Units for Statistics, NUTS) to jednolity i spójny schemat podziału terytorialnego krajów UE. Ma postać pięciostopniowej klasyfikacji hierarchicznej, w której wyróżnia się trzy poziomy regionalne (NUTS 1-3) oraz dwa poziomy lokalne (NUTS 4-5), NUTS-0 to państwa członkowskie, NUTS-1 (makro regiony) mające od 3 do 7 mln ludzi, NUTS-2 (w Polsce obszar jednego województwa) to regiony zamieszkane przez od 800 tys. do $3 \mathrm{mln}$, a NUTS-3 od 150 do 800 tys. osób (podregiony złożone w Polsce z kilku powiatów). 


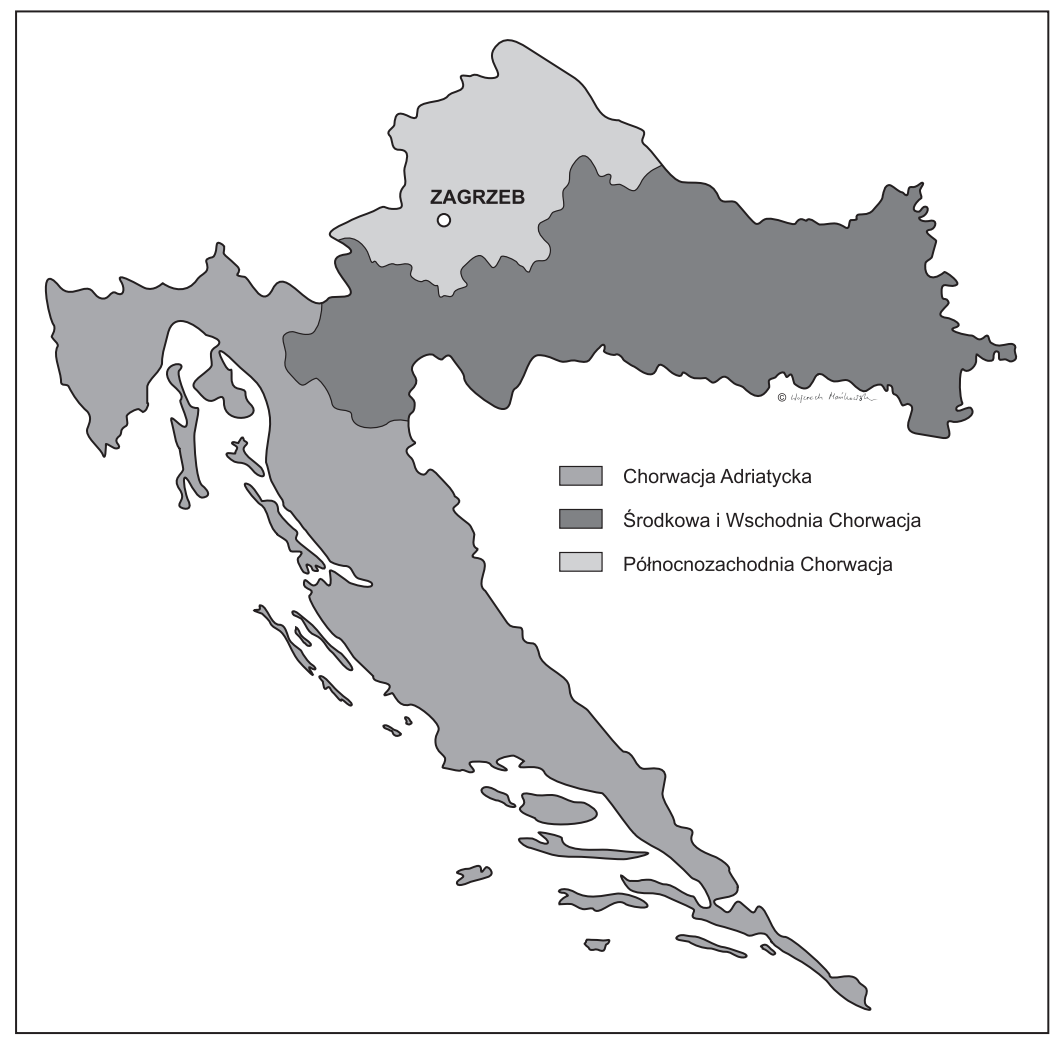

Opracowanie: Wojciech Mańkowski

\section{POLITYKA ENERGETYCZNA}

Kwestie energetyczne przez wiele lat pozostawały poza sferą zainteresowań Wspólnot Europejskich. Większość państw członkowskich uważała, że energetyka ma strategiczne znaczenie dla interesów narodowych i sprzeciwiała się przeniesieniu kompetencji w tym zakresie na poziom wspólnotowy. Przełom nastapił w latach 80., gdy rozpoczęto dyskusję na temat sektora energetycznego na forum europejskim. W 1988 r. Komisja Europejska opublikowała roboczy 
dokument, w którym postulowano utworzenie jednolitego rynku energetycznego. W kolejnych latach opublikowano wiele dokumentów i przyjęto dyrektywy, które stanowiły podwaliny wspólnego, zliberalizowanego rynku energii.

Obecnie głównym wyzwaniem dla państw UE są wzrastająca zależność od importu surowców, rosnące ceny energii oraz zmiany klimatyczne. Unia, celem zapewnienia konkurencyjności, stabilności i bezpieczeństwa dostaw, postuluje stworzenie wewnętrznego rynku energii, zwiększenie efektywności jej wykorzystania oraz wzrost znaczenia energii odnawialnej.

Wskaźnik uzależnienia Chorwacji od importu energii wynosi 45,9\% i jest niższy niż średnia unijna (w 2009 r. $\left.53,9 \%{ }^{12}\right)$. Wskaźnik ten jest niski głównie ze względu na zaopatrywanie się $\mathrm{w}$ gaz i ropę $\mathrm{z}$ własnych zasobów naturalnych, które częściowo pokrywają zapotrzebowanie. Chorwacja importuje energię elektryczna, gaz, ropę, a także węgiel. W krajowej konsumpcji energii największą rolę odgrywa ropa naftowa (50\%), gaz (28\%), mniejsze znaczenie mają źródła odnawialne oraz paliwa stałe (7\%). W październiku 2009 r. przyjęto Strategię Rozwoju Energetyki do 2020 r., która zakłada harmonizację celów polityki krajowej z unijnymi zasadami.

Chorwacja ma rozwinięta, dobrze zintegrowana $\mathrm{z}$ sasiednimi państwami infrastrukturę energetyczna. Spełnia także unijne warunki w zakresie obowiązkowych zapasów paliw płynnych, które pokrywają 90-dniowe średnie dzienne zużycie. Roczne zapotrzebowanie na gaz wynosi ok. $3,1 \mathrm{mld} \mathrm{m}^{3}$ rocznie, $\mathrm{z}$ czego ok. $64 \%$ pokrywane jest $\mathrm{z}$ produkcji własnej. W związku z rosnącym zapotrzebowaniem na gaz i wyczerpywaniem się zasobów w najbliższych latach, uzależnienie od importu gazu będzie najprawdopodobniej wzrastać. Jednocześnie władze chorwackie podejmują

${ }^{12}$ Countries Factsheets. Energy Statistics for EU-27, http://ec.europa. eu/energy/publications/statistics/doc/2011-2009-country-factsheets.pdf. 
działania na rzecz dywersyfikacji szlaków dostaw tego surowca. Do 2008 r. Chorwacja mogła otrzymywać dostawy gazu jedynie przez połaczenie ze Słowenia, o przepustowości 1,8 mld $\mathrm{m}^{3}$ rocznie. W $2011 \mathrm{r}$. uruchomiono dwukierunkowy interkonektor gazowy z Węrami, o przepustowości $6,5 \mathrm{mld} \mathrm{m}^{3}$ rocznie. W przyszłości ma on umożliwić transport gazu z terminalu LNG na wyspie Krk, który pozwoli państwom Europy Środkowej zaopatrywać się w gaz inny niż rosyjski. Oba te projekty wpisują się w unijną strategię budowy korytarza „Północ-Południe”. Rozbudowywane są także sieci gazociagów w Dalmacji, które w przyszłości mają zostać przedłużone do Czarnogóry, a dalej do Albanii, co umożliwiłoby przesył gazu z planowanego gazociagu TAP (Grecja-Albania-Włochy) ${ }^{13}$. Gazociag TAP jest jednym z projektów w ramach unijnej koncepcji Południowego Korytarza (obok Nabucco i ITGI) ${ }^{14}$ przesyłu gazu, który ma pozwolic na dostawy azerskiego gazu przez Turcję, z pominięciem Rosji. Jeśli projekty te zostaną zrealizowane, Chorwacja ma szansę na zajęcie ważnej pozycji w tranzycie gazu do państw Europy Środkowej i Południowej.

\section{POLITYKA KLIMATYCZNA}

UE przywiąuje coraz większą wagę do problematyki zwiazanej z polityka klimatyczna. W 2007 r. Rada Europejska określiła jednomyślnie cele redukcji emisji gazów cieplarnianych do 2020 r. o 20\%, zwiększenie udziału odnawialnych źródeł energii do $20 \%$ i zwiększenie efektywności energetycznej o $20 \%$.

W 2010 r. Chorwacja przyjęła Plan Działań dotyczacy efektywności energetycznej ${ }^{15}$. Większość regulacji, które pozwolą zwiększyć efektywność energetyczną została przyjęta. Rząd zobowiązał się zredukować zapotrzebowanie na energię

\footnotetext{
${ }^{13}$ Gazociag Transatlantycki (Trans Adriatic Pipeline, TAP).

${ }^{14}$ (Interconnector Turkey-Greece-Italy, ITGI).

${ }^{15}$ (National Energy Efficiency Action Plan, NEEAP).
} 
o 9\% do 2016 r. Ten najwyższej rangi dla Chorwacji cel został przyjęty zgodnie z unijnymi zasadami, na podstawie pięcioletniego średniego zapotrzebowania. Chorwacja zobowiązała się także zredukować emisję $\mathrm{CO}_{2}$ o około 800 tys. ton rocznie.

Około 7\% energii zużywanej w Chorwacji pochodzi ze źródeł odnawialnych, co stanowi dość wysoki wskaźnik na tle pozostałych państw UE. Większość tej energii produkowana jest jednak w dużych hydroelektrowniach, które nie są zaliczane do tzw. nowych odnawialnych źródeł energii. Pozyskiwanie energii z małych hydroelektrowni czy elektrowni solarnych lub wiatrowych ma znaczenie marginalne dla produkcji energii. Chorwacja przyjęła w 2010 r. Narodowy Plan na rzecz Energii ze źródeł odnawialnych oraz wprowadziła także taryfy gwarantowane dla energii z tych źródeł. Pomimo przyjętych regulacji, które uznały za strategiczne rozwijanie tego sektora i stworzenie bardzo dobrych warunków dla czerpania energii ze źródeł odnawialnych, Chorwacja nie była w stanie w 2010 r. osiagnaćc założonego celu i pozyskiwać 5,8\% energii elektrycznej ze źródeł odnawialnych. W obecnej sytuacji wydaje się mało prawdopodobne, by Chorwacja osiagnęła w 2020 r. cel założony przez UE.

Unia wspiera także stosowanie biopaliw i biokompotentów. Chorwacja zadeklarowała, że do 2010 r. zwiększy udział biopaliw o $5,75 \%$.

\section{Współpraca w dziedzinie polityki zagranicznej}

Przystapienie Chorwacji do Unii Europejskiej będzie działało dwuwektorowo w szeroko pojętej sferze polityki zagranicznej. Jeden wektor odnosić się będzie do pozycji Chorwacji na arenie międzynarodowej, natomiast drugi - do obszaru zainteresowań, związanego z interesami Zagrzebia.

Przede wszystkim wzmocnieniu ulegnie pozycja Chorwacji w Europie i pośrednio na świecie. Członkostwo 
w Unii Europejskiej sytuuje państwa członkowskie na jednym z najwyższych poziomów na kontynencie europejskim. Na forum UE Chorwacja będzie mogła przedstawiać swoje stanowisko i go bronić w otoczeniu takich mocarstw, jak Niemcy, Francja czy Wielka Brytania. W wielu przypadkach, a praktycznie we wszystkich najważniejszych dla swojej racji stanu kwestiach, Chorwacja będzie miała prawo veta. W historii tego państwa to przełomowy moment, który wcześniej nie miał precedensu. Regularne spotkania przedstawicieli Chorwacji odpowiedzialnych za praktycznie każdy element funkcjonowania państwa, społeczeństwa i gospodarki wzmacnia z zasady więzi łączące uczestniczące państwa i przywódców.

Z drugiej strony, Unia Europejska nie będzie ograniczać Chorwacji w jej działaniu, tak jak dzieje się w przypadku państw, które chca, czy chciały odgrywać rolę lidera i motoru integracji europejskiej. W związku z tym zmuszone sa często do przypatrywania się polityce zagranicznej z dużo szerszej perspektywy, nie przesłoniętej wyłącznie swoim interesem. Podobnie zachowują się (potencjalni) liderzy regionu, którzy - w celu osiagnięcia czy utrzymania swojej pozycji - powinni brać pod uwagę interesy poszczególnych partnerów. Pozycja i geopolityczne położenie państwa chorwackiego wykluczają na kilkanaście lat możliwość ogrywania takiej roli.

Akcesja Chorwacji do Unii Europejskiej postawi to państwo w dużo korzystniejszym położeniu w odniesieniu do Serbii, Bośni i Hercegowiny, ale także i pozostałych państw regionu - Macedonii, Kosowa i Albanii. W tym kontekście, patrząc przez pryzmat doświadczenia słoweńskiego, Chorwacja zyska potężnego poplecznika w sporach regionalnych. Niestety, członkostwo w UE oznacza wystapienie ze Środkowo-Europejskiego Porozumienia o Wolnym Handlu. W 2004 r. takie decyzje musiały podjęć Polska, Węgry, Czechy i Słowacja, a w 2007 r. Bułgaria i Rumunia. Przynależność do jednej strefy wolnego handlu 
wyklucza praktycznie możliwość partycypacji w innej strefie tego typu. Chorwacja zobowiązana będzie podpisać szereg umów i konwencji międzynarodowych ${ }^{16}$.

Ze względu na swój rozmiar, potencjał demograficzny i gospodarczy, państwo chorwackie nie będzie w stanie rozszerzyć zakresu własnej polityki zagranicznej na wiele nowych kierunków. Gospodarcze i finansowe więzy łączące ten kraj z partnerami niemieckimi, austriackimi i włoskimi, a w mniejszym stopniu także węgierskimi, słoweńskimi i bośniackimi, wskazują na ograniczenia, jakie wpływać będą na politykę zagraniczną Zagrzebia. Ponadto obecność Chorwacji w dwóch ważnych przedsięwzięciach UE, tj. Unii dla Śródziemnomorza i Strategii UE dla Regionu Dunajskiego kieruje uwagę tego państwa na południowy wschód. Obydwa te kierunki polityki, z punktu widzenia polskiej racji stanu, odwracają uwagę UE od kluczowych dla Warszawy spraw wschodnich.

Polskie władze moga jednak liczyć na to, że Chorwacja stanie się kolejnym państwem przychylnym wobec dalszego rozszerzenia Unii Europejskiej, które z większym zrozumieniem niż Irlandia, Portugalia, Dania czy Holandia, patrzeć będzie na relacje między Rosja, Białorusia, Ukraina, Mołdawią a UE.

\section{Wyzwania stojące przed Chorwacją}

Zakończenie negocjacji jest ogromnym sukcesem chorwackiego rządu i stanowi ukoronowanie procesu transformacji gospodarczo-społecznej. Jednocześnie jednak nie jest to koniec wyzwań stojących przed władzami chorwackimi.

Finalizujac proces negocjacji z Chorwacja, UE zdecydowała się na bezprecedensowy krok i postanowiła

16 Ich wyczerpująca, 13-stronicowa lista zamieszczona została w Załączniku I i II do Traktatu Akcesyjnego. 
kontynuować proces monitorowania postępów reform poprzez publikowanie dorocznych raportów. W obszarze najbardziej dla Chorwacji problematycznym, tj. sądownictwa i praw podstawowych, raporty będa publikowane nawet częściej, dwa razy w roku. Oznacza to, że rząd chorwacki będzie zmuszony do dalszego wdrażania reform. Ich zaprzestanie może rodzić problemy z ratyfikacją Traktatu Akcesyjnego, tym bardziej że w przypadku Chorwacji nie zdecydowano się na zastosowanie Mechanizmu Współpracy i Weryfikacji, w ramach którego monitorowano postępy w reformie wymiaru sprawiedliwości i walki z korupcja w Rumunii i Bułgarii, już po uzyskaniu przez te państwa członkostwa w Unii Europejskiej. Oznacza to, że po ratyfikacji Traktatu Akcesyjnego kraje członkowskie utracą możliwość kontroli dostosowania Zagrzebia do zasad unijnych. W związku z tym państwa członkowskie moga wydłużać procedurę ratyfikacji i uzależniać ją od kolejnych raportów.

Wyzwaniem dla władz w Zagrzebiu będzie także poprawa sytuacji gospodarczej Chorwacji. Szybki wzrost był dotychczas spowodowany dużymi inwestycjami infrastrukturalnymi rządu, a także krajowym popytem finansowanym przez kredyty chętnie udzielane przez banki. Globalny kryzys gospodarczy podciał kruche fundamentu wzrostu i spowodował, że okres stagnacji w Chorwacji jest dłuższy niż w pozostałych państwach regionu. Zaowocowała ona jednym z najwyższych wskaźników bezrobocia w UE (więcej bezrobotnych jest tylko w Hiszpanii). Problemem są także wysokie obciażenie podatkami i opłatami parapodatkowymi oraz niekorzystny klimat dla prowadzenia działalności gospodarczej, spowodowany rozbudowaną biurokracjac. Czynniki te hamują inwestycje. Społeczeństwo i elity polityczne maja nadzieję, że członkostwo w UE stanie się impulsem dla szybkiego rozwoju gospodarczego dzięki poprawie wiarygodności na arenie międzynarodowej, nielimitowanemu dostępowi do europejskiego rynku oraz funduszom strukturalnym. Będzie to na pewno pozytywnie wpływać na sytuację, ale konieczne 
są także dalsze reformy, by zbudować podstawy do stabilnego wzrostu w przyszłości. Fundamentalne zmiany sa konieczne w administracji, służbie zdrowia, pomocy społecznej oraz systemie emerytalnym.

Kolejnym etapem integracji Chorwacji z UE będzie uzyskanie członkostwa w strefie euro oraz „systemie Schengen". W myśl deklaracji minister finansów w rządzie Jadranki Kosor, Martiny Dalić, biorąc pod uwagę wysoki stopień „euronizacji” gospodarki chorwackiej, przyjęcie wspólnej waluty będzie naturalnym procesem i rząd będzie dążył do spełnienia kryteriów z Maastricht już w 2013 r. ${ }^{17}$ Dla gospodarki chorwackiej, która jest niewielka i silnie uzależniona od euro (ok. 80\% depozytów jest denominowanych w tej walucie), minimalizowanie ryzyka kursowego jest poważnym obciążeniem dla gospodarki. Z tego względu szybkie przyjęcie euro wydaje się korzystne dla Chorwacji. W tym przypadku państwo rezygnuje jednak z możliwości poprawienia swojej konkurencyjności poprzez deprecjację własnej waluty. W związku z tym SDP, która wygrała wybory w grudniu 2011 r., jest zdecydowanie bardziej sceptyczna wobec euro. Również międzynarodowi analitycy uważaja, że ze względu na skalę kryzysu gospodarczego, szybkie spełnienie kryterium konwergencji i wstapienie do unii monetarnej będzie niemożliwe. Według badań przeprowadzonych przez Chorwackie Stowarzyszenie Bankowców większość ekspertów spodziewa się, że stanie się to dopiero w latach 2018-2023.

Jeśli chodzi o wstapienie do „strefy Schengen” rząd Chorwacji deklaruje, że spełni ona wszystkie warunki akcesji w dwa lata od przystapienia do UE, tzn. w 2015 r. Głównym wyzwaniem dla Zagrzebia w tym zakresie

${ }^{17}$ K. Andrusz, Euro Adoption Would Be 'Natural' for Croatia, Finance Chief Says, 9 IX 2011, http://www.bloomberg.com/news/201109-09/euro-adoption-would-be-natural-for-croatia-finance-chief-says. html. 
będzie kontrola zewnętrznych granic Unii, czego nie ułatwia długość linii granicznej (1377 km z państwami poza UE), ani kształt państwa (liczne wyspy i enklawa w okolicach Dubrownika). W ostatnich latach Chorwacja systematycznie poprawia kontrolę nad granicami w ramach Planu Działania na Rzecz Zintegrowanego Zarządzania Granicami i harmonizuje prawodawstwo $z$ normami Schengen. Reformy w tym zakresie będa finansowane $\mathrm{m}$. in. z Funduszu na rzecz Schengen, w ramach którego $120 \mathrm{mln}$ euro przeznaczonych jest dla Chorwacji (40 mln euro w 2013 i 80 mln w 2014 r.) Decyzja o przystapieniu Chorwacji do „strefy Schengen” będzie wymagała zgody wszystkich członków, a biorąc pod uwagę obecne problemy Rumunii i Bułgarii, nie można wykluczyć, że data chorwackiej akcesji się opóźni. Zdecydowanie łatwiejsze byłoby także przystapienie do „strefy Schengen” wszystkich państw bałkańskich, co znacznie ułatwiłoby kontrolę granic oraz zmniejszyłoby koszty jej ochrony. Biorąc pod uwagę obecne tempo integracji tych państw z UE niewielkie sa szanse, by uzyskały one członkostwo przed rokiem 2020. Może to opóźnić integrację Chorwacji ze „strefą Schengen”.

Dla samej Chorwacji poważnym wyzwaniem sa przemiany, jakie obecnie zachodza w Unii Europejskiej. W 2013 r. Zagrzeb uzyska członkostwo we wspólnocie, która najpewniej będzie wyglądała zupełnie inaczej niż UE, z która rozpoczynano negocjacje w 2005 r. Nie wiadomo, jak w przyszłości będzie wyglądała unia walutowa, zreformowana ma zostać „strefa Schengen”, polityka rolna czy polityka spójności. 



\section{Rozdział IV \\ Konkluzje i wnioski dla Polski}

Jak słusznie wskazała Komisja Europejska: „Rozszerzenie Unii Europejskiej poprzez przystapienie Chorwacji przyczyni się do wzmocnienia stabilności, wolności i dobrobytu w Europie. Oczekuje się, że Chorwacja będzie w dalszym ciagu pełnić aktywna rolę we współpracy regionalnej Bałkanów Zachodnich. Komisja z zadowoleniem przyjęła deklarację Chorwacji na temat propagowania wartości europejskich w Europie Południowo-Wschodniej, a w szczególności zobowiązanie Chorwacji, że kwestie dwustronne nie powinny utrudniać procesu przystapienia krajów kandydujących. Przystapienie Chorwacji potwierdza zaangażowanie UE w perspektywę europejską Bałkanów Zachodnich"1.

Ze względu na słabe więzi polityczne, gospodarcze czy społeczne pomiędzy Polska a Chorwacja, przystapienie tego drugiego państwa do Unii powinno wywierać na nasz kraj wpływ tylko w takim stopniu, w jakim wpłynie ono na całokształt zjednoczonej Europy. Członkostwo Chorwacji w Unii Europejskiej będzie miało bezpośredni wpływ przede wszystkim na państwa z nią sąsiadujące oraz najbardziej w tym regionie zaangażowane, jak Austria, Węgry,

1 Opinia Komisji w sprawie wniosku Republiki Chorwacji o przystapienie do Unii Europejskiej, Komisja Europejska, Bruksela $12 \mathrm{X}$ 2011, KOM(2011) 667, http://ec.europa.eu/enlargement/pdf/key_documents/2011/package/hr_opinion_2011_pl.pdf. 
Słowenia, Włochy czy Niemcy. Polska tylko pośrednio odczuje skutki „drugiego bałkańskiego rozszerzenia”.

Członkostwo Chorwacji w Unii wpłynie w sposób nieznaczny na pozycję Polski w procesie decyzyjnym UE. Niewielka liczba mieszkańców oraz stosunkowo mały potencjał gospodarczy oznacza, że układ sił w instytucjach unijnych nie ulegnie poważnej zmianie. Na pewno Chorwacji potrzebny będzie pewien czas przeznaczony na wypracowywanie polityki europejskiej oraz na naukę szukania kompromisów i wspólnych rozwiązań na arenie europejskiej.

Zmianom ulegnie natomiast wewnętrzna struktura Unii Europejskiej. Wzmocniona zostanie na pewno, skupiona wokół Unii dla Śródziemnomorza, grupa państw południowoeuropejskich, która obecnie składa się z Francji, Portugalii, Hiszpanii, Malty, Grecji, Cypru, Słowenii, i Włoch. Utworzona właśnie Strategia dla Regionu Naddunajskiego zyskała już Chorwację, która niedługo wzmocni tę grupę na forum unijnym. Strategia dla Regionu Naddunajskiego skieruje z pewnością więcej uwagi na Europę Południowo-Wschodnia, który to kierunek bardziej odpowiada interesom Polski niż wektor południowy związany z Afryką Północna.

Zwiększenie grupy małych państw członkowskich UE może wpłynąć dodatnio na rolę, jaką odgrywają duże państwa, do których zalicza się przecież Polska. Co więcej funkcjonująca obecnie formuła V4 +, czyli cztery kraje Grupy Wyszehradzkiej plus państwa współpracujące (np. Rumunia), zostanie także poszerzona, obejmując kolejne kraje Europy Środkowowschodniej. Będzie to miało pozytywne przełożenie na politykę polską w Unii Europejskiej. Można też mieć nadzieję, że dla Chorwacji nie będzie obojętne np. Partnerstwo Wschodnie, czy kierunek wschodni europejskiej polityki zagranicznej.

Obszary integracji, takie jak Wspólna Polityka Rolna czy polityka spójności, zyskają nowego beneficjenta o podobnym do polskiego poziomie rozwoju gospodarczego, tzn. wymagającego przez stosunkowo jeszcze długi okres 
znacznej pomocy finansowej. Zależeć to będzie oczywiście także od tempa i kierunków zmian, jakie dotyczyć będa obydwu tych polityk po roku 2013. Przystapienie do Unii Europejskiej, a następnie wsparcie uzyskane w ramach Wspólnej Polityki Rolnej przyczyni się jednak bez wątpienia do wzmocnienia i rozwoju rolnictwa chorwackiego. Polska polityka w tych obszarach może, ale nie musi, zyskać sojusznika. Dużo zależeć będzie od umiejętności przekonania chorwackich partnerów do polskiego stanowiska w tym zakresie.

W dziedzinie polityki energetycznej Chorwacja stała się już na tym etapie jednym z kluczowych państw tranzytowych dla energii pochodzącej z południowego wschodu i w mniejszym stopniu z Rosji. Przyczynia się to do dalszej dywersyfikacji dostaw źródeł energii, choć dla Polski będzie miało to znaczenie jedynie pośrednie, ze względu na brak znacznych powiązań sieci energetycznych.

Można zaryzykować stwierdzenie, że poszerzenie Unii o państwo chorwackie wpłynie spowalniająco na proces wewnętrznej integracji. Będzie to tym bardziej prawdopodobne, im słabiej przygotowana będzie Chorwacja do sprawnego funkcjonowania w Unii. Polska powinna więc wspierać jak najlepsze przygotowanie Chorwacji do członkostwa w UE, w taki sposób, aby nie dostarczać argumentów, które mogłyby zostać wykorzystane przez państwa niechętne dalszej integracji i poszerzeniu Unii. Przyłączenie Chorwacji do Unii Europejskiej nie powinno, biorąc pod uwagę potencjał gospodarczy oraz sytuację demograficzna tego kraju, doprowadzić do napływu obywateli chorwackich do Polski. Ponadto należy podkreślić, że Chorwacja jest tradycyjnie powiązana z państwami Europy Zachodniej i Południowej, takimi jak Austria, Niemcy czy Włochy, i to właśnie te kraje stanowią potencjalny cel migracji Chorwatów. 



\section{Wskazówki bibliograficzne}

Bibliografia poświęcona współczesnej sytuacji w Chorwacji jest na polskim rynku wydawniczym stosunkowo skromna. Rzadkość stanowią książki Krzysztofa Krysieniela System polityczny Republiki Chorwacji (Poznań-Chorzów 2007) i Małgorzaty Łakoty-Micker Proces akcesji Republiki Chorwacji do Unii Europejskiej (Wrocław 2011). Inne ważne pozycje dotyczą historii i rozpadu Jugosławii oraz współczesnej sytuacji politycznej Bałkanów Zachodnich, sa to przede wszystkim prace: Wiesława Walkiewicza Jugostawia. Byt wspólny i rozpad (Warszawa 2000) i Jugostawia. Państwa sukcesyjne (Warszawa 2009); Michała Jerzego Zachariasa Komunizm. Federacja. Nacjonalizmy. System władzy $w$ Jugostawii 1943-1991. Powstanie, przeksztatcenia, rozkład (Warszawa 2004); Lesliego Bensona Jugostawia. Historia w zarysie (Kraków 2011); Mieczysława Tantego Batkany w XX wieku. Dzieje polityczne (Warszawa 2003); Vademecum batkanisty. Lata 500-2007, pod redakcja Ilony Czamańskiej i Zdzisława Pentka (Poznań 2009); Sebastiana Wojciechowskiego Integracja $i$ dezintegracja Jugostawii na przełomie XX i XXI wieku (Poznań 2002); Macieja Kuczyńskiego Batkańska pożoga. Wojny $i$ konflikty na Batkanach $w$ latach 1981-1999 (Warszawa 1999); Marka Waldenberga Rozbicie Jugostawii. Od separacji Stowenii do wojny kosowskiej (Warszawa 2003) i Rozbicie Jugosławii. Jugostowiańskie lustro międzynarodowej polityki (Warszawa 2005); Mirelli KorzeniewskiejWiszniewskiej Serbia pod rzadami Slobodana Miloševicia. 
Serbska polityka wobec rozpadu Jugostawii w latach dziewięćdziesiatych XX wieku (Kraków 2008) i Ksztattowanie relacji między państwami bytej Jugostawii $w$ ostatnim dziesięcioleciu - zarys problemu (Lublin 2010); Jacka Wojnickiego Proces instytucjonalizacji przemian ustrojowych w państwach postjugosłowiańskich (Pułtusk 2007) i Przeobrażenia ustrojowe państw postjugosłowiańskich (1990-2003) (Pułtusk 2003); Ewy Bujwid-Kurek Państwa pojugosłowiańskie. Szkice politologiczne (Kraków 2008); wymienianych już wcześniej Krzysztofa Krysieniela i Jacka Wojnickiego Partie i systemy partyjne państw bytej Jugostawii (Bośnia i Hercegowina, Chorwacja, Czarnogóra, Macedonia, Serbia, Stowenia) (Pułtusk-Warszawa 2009); Batkany Zachodnie a integracja europejska. Perspektywy $i$ implikacje, pod red. Rafała Sadowskiego i Jana Musia (Warszawa 2008); Bośnia i Hercegowina 15 lat po Dayton. Przeszłość - teraźniejszość - perspektywy. Studia i szki$c e$, pod red. Pawła Chmielewskiego i Sławomira Lucjana Szczesio (Łódź 2011), a także wydawany od 1991 r. przez Instytut Studiów Politycznych PAN Rocznik „Europa Środkowo-Wschodnia", w którym znajduje się wiele informacji o państwach byłej Jugosławii.

Nieprzebrane źródło analiz, komentarzy i artykułów stanowią zasoby kliku ośrodków analitycznych zajmujacych się Bałkanami. Sa to: Ośrodek Studiów Wschodnich (http://www.osw.waw.pl/) oraz Polski Instytut Spraw Międzynarodowych (http://www.pism.pl/) czy Centrum Analiz Społeczno-Ekonomicznych (http://case.com.pl/). Dostępne, zdygitalizowane materiały zawierają zarówno krótkie omówienia najważniejszych wydarzeń w regionie Bałkanów, także Chorwacji, jak i pogłębione kilkulub kilkudziesięciostronicowe opracowania analityczne. Stosunkowo dużo opracowań na temat Chorwacji znajduje się również na stronie Portalu Spraw Zagranicznych (http://www.psz.pl/) oraz, w języku angielskim, na http:// www.euractiv.com/. 
Dokumenty i oficjalne dane dotyczace procesu akcesji Chorwacji do Unii Europejskiej, także w języku angielskim, znaleźć można na stronie internetowej Ministerstwa Spraw Zagranicznych i Integracji Europejskiej Republiki Chorwacji (http://www.mvep.hr) oraz Komisji Europejskiej (http://ec.europa.eu/enlargement/index_pl.htm). 



\section{Załączniki}

\section{Załącznik 1 \\ Chronologia integracji Chorwacji \\ z Unią Europejską}

\section{maj 1999 r.}

Komisja Europejska zaproponowała utworzenie Procesu Stabilizacji i Stowarzyszania (Stabilisation and Association Process, SAP) dla Albanii, Bośni i Hercegowiny, Chorwacji i Federalnej Republiki Jugosławii.

\section{0 czerwca 1999 r.}

Uzgodniony został Pakt Stabilności - dokument polityczny, którego strategicznym celem była stabilizacja Europy Południowo-Wschodniej poprzez integrację tego regionu ze strukturami euroatlantyckimi oraz poprzez wzmocnienie współpracy wielostronnej.

\section{5 lutego 2000 r.}

Utworzono Wspólny Komitet Konsultacyjny pomiędzy Chorwacją a UE.

\section{0 maja 2000 r.}

Komisja Europejska przedstawiła program CARDS (Community Assistance for Reconstruction, Development and Stabilisation) - instrument pomocy finansowej i technicz- 
nej przeznaczony dla Europy Południowo-Wschodniej w latach 2000-2006.

\section{4 maja 2000 r.}

Komisja Europejska pozytywnie oceniła Chorwacje przed rozpoczęciem negocjacji Porozumienia o Stabilizacji i Stowarzyszeniu (Stabilisation and Association Agreement, SAA) pomiędzy Chorwacją a UE.

\section{3 czerwca 2000 r.}

Rząd Chorwacji przyją Raport Komisji Europejskiej na temat SAA, potwierdzając tym samym, że państwo chorwackie wypełniło warunki niezbędne do rozpoczęcia negocjacji.

\section{3 czerwca 2000 r.}

Chorwacja została członkiem programu EUREKA.

\section{6 listopada 2000 r.}

Mianowano członków zespołu negocjującego konkluzje SAA.

\section{4 listopada 2000 r.}

Szczyt w Zagrzebiu - początek negocjacji SAA pomiędzy Chorwacją a Unia.

\section{Listopad 2000 r.}

Rząd Republiki Chorwacji przyjął wytyczne do negocjacji konkluzji SAA.

\section{5 grudnia 2000 r.}

Rada Unii Europejskiej przyjęła program pomocowy CARDS. 


\section{8 grudnia $2000 \mathrm{r}$.}

Pierwsza runda negocjacji SAA została zakończona.

8 lutego 2001 r.

W parlamencie Republiki Chorwacji utworzony został Komitet Integracji Europejskiej.

26 lutego 2001 r.

Początek drugiej rundy negocjacji SAA.

29 października 2001 r.

Porozumienie o Stabilizacji i Stowarzyszeniu oraz Porozumienie Przejściowe pomiędzy Chorwacją a Unią Europejską zostały podpisane w Luksemburgu.

5 grudnia 2001 r.

Chorwacki parlament ratyfikował SAA.

12 grudnia $2001 \mathrm{r}$.

Parlament Europejski ratyfikował SAA.

28 stycznia 2002 r.

Rada Unii Europejskiej potwierdziła Porozumienie Przejściowe.

\section{1 lutego 2002 r.}

Austria ratyfikowała SAA.

1 marca 2002 r.

W życie weszło Porozumienia Przejściowe.

3 kwietnia 2002 r.

Komisja Europejska opublikowała pierwszy roczny Raport SAP o Chorwacji. 
17 kwietnia 2002 r.

Irlandia ratyfikowała SAA.

30 kwietnia 2002 r.

Dania ratyfikowała SAA.

\section{3 czerwca 2002 r.}

Chorwacki parlament potwierdził Porozumienie Ramowe na temat generalnych zasad uczestnictwa Chorwacji w programach wspólnotowych.

\section{2 lipca 2002 r.}

Niemcy ratyfikowały SAA. Komisja Europejska i Rząd Republiki Chorwacji podpisały Porozumienie o Priorytetach Wieloletniego Programu Wskazującego (Multiannual Indicative Programme) (CARDS) na lata 2002-2004.

19 września 2002 r.

Hiszpania ratyfikowała SAA.

\section{8 grudnia 2002 r.}

Parlament chorwacki przyją rezolucję o akcesji Chorwacji do Unii Europejskiej.

\section{4 lutego 2003 r.}

Szwecja ratyfikowała SAA.

\section{1 lutego 2003 r.}

Chorwacja złożyła wniosek o członkostwo w Unii Europejskiej.

4 marca 2003 r.

Francja ratyfikowała SAA. 


\section{4 kwietnia 2003 r.}

Rada Unii Europejskiej zwróciła się do Komisji Europejskiej o przygotowanie opinii na temat wniosku chorwackiego o członkostwo w UE.

3 czerwca 2003 r.

Luksemburg ratyfikował SAA.

5 czerwca 2003 r.

Grecja ratyfikowała SAA.

1 lipca 2003 r.

Portugalia ratyfikowała SAA.

\section{0 lipca 2003 r.}

Komisja Europejska wręczyła władzom chorwackim kwestionariusz zawierajacy 4560 pytań związanych z wnioskiem Chorwacji o członkostwo.

9 października 2003 r.

Władze chorwackie zwróciły Komisji Europejskiej wypełniony kwestionariusz.

\section{1 grudnia 2003 r.}

Belgia ratyfikowała SAA.

19 grudnia 2003 r.

Finlandia ratyfikowała SAA.

26 lutego 2004 r.

Chorwacja skończyła pierwszą rundę negocjacji z Komisja Europejską w sprawie Protokołu 7 (handel) do SAA. 


\section{1 marca 2004 r.}

Parlament Europejski zawiesił działania Delegacji dla Europy Południowo-Wschodniej; powołany został specjalny Komitet ds. kontaktów z Chorwacją.

\section{5 marca 2004 r.}

Republika Chorwacji została pełnoprawnym członkiem programu CADSES.

\section{0 kwietnia 2004 r.}

Komisja Europejska wydała pozytywną opinię (avis) w sprawie chorwackiego wniosku o członkostwo w UE.

30 kwietnia 2004 r.

Holandia ratyfikowała SAA.

\section{8 czerwca 2004 r.}

Chorwacja uzyskała status państwa-kandydata.

\section{3 września 2004 r.}

Rada Unii Europejskiej przyjęła Partnerstwo Europejskie dla Chorwacji.

\section{6 października 2004 r.}

Komisja Europejska opublikowała Strategię Przedakcesyjną dla Chorwacji.

\section{7 grudnia 2004 r.}

Rada Europejska wyznaczyła datę rozpoczęcia negocjacji akcesyjnych, podkreślając jednak konieczność współpracy Chorwacji z Międzynarodowym Trybunałem Karnym dla byłej Jugosławii. 


\section{9 maja 2005 r.}

Chorwacki parlament przyją następujące dokumenty związane z integracją europejska:

- Oświadczenie o Wspólnych Działaniach Rządu i Parlamentu;

- Deklarację o Fundamentalnych Zasadach Negocjacji;

- Decyzję o Utworzeniu Narodowego Komitetu Monitorującego Negocjacje.

\section{1 lutego 2005 r.}

Weszło w życie SAA.

\section{6 marca 2005 r.}

Rada Unii Europejskiej przyjęła Ramy Negocjacyjne dla Chorwacji, ale nie potrafiła uzyskać konsensusu w sprawie otwarcia negocjacji akcesyjnych - negocjacje nie zostały podjęte.

\section{6 kwietnia 2005 r.}

Pierwsze spotkanie chorwacko-unijnej Rady Stabilizacji i Stowarzyszenia.

\section{3 października 2005 r.}

Pozytywny raport prokurator ICTY Carli del Ponte na temat współpracy Zagrzebia i Hagi. Rozpoczęto negocjacje akcesyjne pomiędzy Chorwacją a UE.

\section{0 października 2005 r.}

Początek przeglądu prawodawstwa chorwackiego pod względem jego zgodności z acquis communautaire.

\section{8 października 2005 r.}

Pierwsza międzyrządowa konferencja, na której ustalono zasady i procedury negocjacji akcesyjnych oraz omówiono 
wstępne założenia prac oparte na programie przeglądu prawodawstwa w poszczególnych rozdziałach negocjacyjnych.

\section{7 grudnia 2005 r.}

Generał Ante Gotovina został złapany na Wyspach Kanaryjskich i oddany w ręce międzynarodowego wymiaru sprawiedliwości.

\section{0 lutego 2006 r.}

Rada Unii Europejskiej przyjęła Partnerstwo Akcesyjne dla Chorwacji.

\section{0 kwietnia 2006 r.}

Drugie spotkanie Rady Stabilizacji i Stowarzyszenia.

\section{2 czerwca 2006 r.}

Otwarto i tymczasowo zamknięto rozdział 25 - Nauka i Badania.

\section{8 października 2006 r.}

Zakończono przegląd prawodawstwa.

\section{1 grudnia 2006 r.}

Otwarto i tymczasowo zamknięto rozdział 26 - Edukacja i Kultura.

\section{1 grudnia 2006 r.}

Otwarto rozdziały: 17 - Gospodarka i Unia Monetarna, 20

- Przedsiębiorstwa i Polityka Przemysłowa oraz 29 - Unia Celna.

6 marca 2007 r.

Odbyło się trzecie spotkanie Rady Stabilizacji i Stowarzyszenia. 
29 marca 2007 r.

Otwarto rozdział 7 - Prawo Własności Intelektualnej.

26 czerwca 2007 r.

Otwarto rozdziały: 3 - Wolność przepływu usług, 6 - Prawo Spółek, 9 - Usługi Finansowe, 10 - Społeczeństwo Informacyjne i Media, 18 - Statystyki, i 32 - Kontrola Finansowa.

\section{2 października 2007 r.}

Otwarto rozdziały: 28 - Ochrona Zdrowia i Konsumentów oraz 30 - Stosunki Zewnętrzne.

\section{9 grudnia 2007 r.}

Otwarto rozdziały 21 - Sieci Transeuropejskie i 33 - Ustalenia Budżetowe i Finanse.

\section{2 lutego 2008 r.}

Rada Unii Europejskiej przyjęła zrewidowane Partnerstwo Akcesyjne dla Chorwacji.

\section{1 kwietnia 2008 r.}

Otwarto rozdziały 14 - Polityka Transportowa oraz 15 Energia.

28 kwietnia 2008 r.

Czwarte spotkanie Rady Stabilizacji i Stowarzyszenia.

\section{7 czerwca 2008 r.}

Otwarto rozdziały 2 - Wolność Przepływu Pracowników oraz 19 - Polityka Społeczna i Zatrudnienie.

\section{5 lipca 2008 r.}

Otwarto rozdział 1 - Swoboda Przepływu Towaru, a tymczasowo zamknięto rozdział 20 - Przedsiębiorstwa i Polityka Przemysłowa. 


\section{0 października 2008 r.}

Rozdział 30 - Stosunki Zewnętrzne został tymczasowo zamknięty.

\section{9 grudnia 2008 r.}

Otwarto rozdział 5 - Zamówienia Publiczne; tymczasowo zamknięto rozdział 7 - Prawo Własności Intelektualnej, 10 - Społeczeństwo Informacyjne i Media oraz 17 - Gospodarka i Polityka Monetarna.

\section{7 kwietnia 2009 r.}

Piąte spotkanie Rady Stabilizacji i Stowarzyszenia.

\section{2 października 2009 r.}

Otwarto rozdziały: 4 - Swobodny Przepływ Kapitału, 11 Rolnictwo i Rozwój Obszarów Wiejskich, 12 - Bezpieczeństwo Żywności, Weterynaria i Inspekcja Fitosanitarna, 16 - Podatki, 22 - Polityka Regionalna i Koordynacja Instrumentów Strukturalnych oraz 24 - Sprawiedliwość, Wolność i Bezpieczeństwo; tymczasowo zamknięto rozdziały: 2 - Swobodny Przepływ Pracowników, 6 - Prawo Spółek, 18 - Statystyki, 21 - Sieci Transeuropejskie i 29 - Unia Celna.

\section{4 listopada 2009 r.}

Chorwacja i Słowenia podpisały porozumienie o przekazaniu problemu odnoszącego się do konfliktu dotyczącego Zatoki Pirańskiej międzynarodowemu arbitrażowi.

\section{7 listopad 2009 r.}

Zamknięto tymczasowo rozdziały: 9 - Usługi Finansowe, 15 - Energia, 28 - Ochrona Zdrowia i Konsumentów.

\section{1 grudnia 2009 r.}

Tymczasowo zamknięto rozdziały 3 - Swobodny Przepływ Usług oraz 19 - Polityka Społeczna i Zatrudnienie. 


\section{9 lutego 2010 r.}

Otwarto rozdziały 13 - Rybołówstwo i 27 - Środowisko.

\section{9 kwietnia 2010 r.}

Rozdział 1 - Swobodny Przepływ Towarów został tymczasowo zamknięty.

\section{7 czerwca $2010 \mathrm{r}$.}

Rozdziały tymczasowo zamknięte: 12 - Bezpieczeństwo Żywności, Weterynaria i Inspekcja Fitosanitarna oraz 32 Kontrola Finansowa.

\section{0 czerwca 2010 r.}

Otwarto rozdziały: 8 - Polityka Konkurencji, 23 - Sąownictwo i Prawa Podstawowe, 31 - Polityka Zagraniczna, Bezpieczeństwa i Obrony. Rozdziały tymczasowo zamknięte: 5 - Zamówienia Publiczne oraz 16 - Podatki.

\section{5 listopada 2010 r.}

Rozdziały tymczasowo zamknięte: 4 - Swobodny Przepływ Kapitału, 14 - Polityka Transportowa. Otwarto i tymczasowo zamknięto rozdział 34 - Instytucje.

\section{2 grudnia 2010 r.}

Zamknięto tymczasowo rozdziały: 24 - Sprawiedliwość, Wolność i Bezpieczeństwo, 27 - Srodowisko, 31 - Polityka Zagraniczna, Bezpieczeństwa i Obrony.

\section{0 czerwca 2011 r.}

Komisja Europejska zarekomendowała zakończenie negocjacji oraz wyznaczenie daty akcesji na 1 lipca 2013 r.

\section{4 czerwca 2011 r.}

Rada Europejska wezwała do zakończenia negocjacji akcesyjnych i podpisania traktatu akcesyjnego do końca 2011 r. 
30 czerwca 2011 r.

Zakończenie negocjacji akcesyjnych.

17 września 2011 r.

Polski premier Donald Tusk przekazał w Zagrzebiu szefowej chorwackiego rządu Jadrance Kosor projekt Traktatu Akcesyjnego Chorwacji z UE

\section{2 października 2011 r.}

Komisja Europejska wydała pozytywną opinię na temat planowanej akcesji Chorwacji do Unii Europejskiej.

\section{9 grudnia 2011 r.}

Podpisanie w Brukseli Traktatu Akcesyjnego.

\section{1 lipca 2013 r.}

Planowana data przystapienia Chorwacji do Unii Europejskiej 


\begin{tabular}{|c|c|c|c|c|c|}
\hline \multirow{9}{*}{ 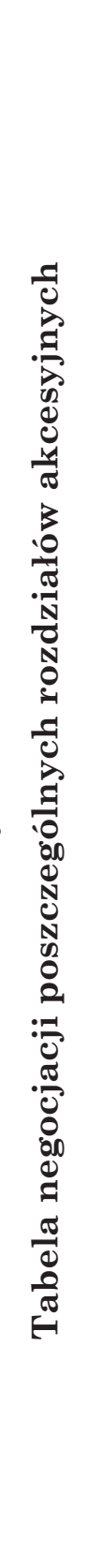 } & 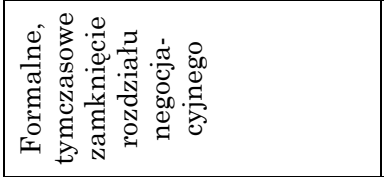 & 0 & 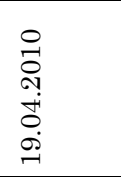 & 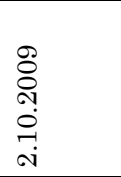 & 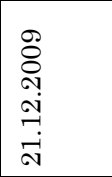 \\
\hline & 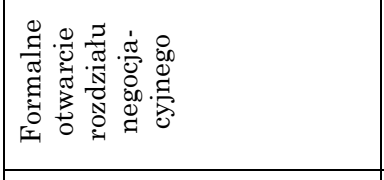 & $\infty$ & 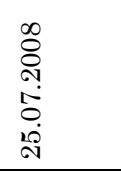 & 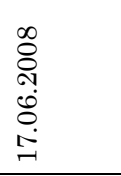 & 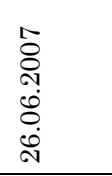 \\
\hline & 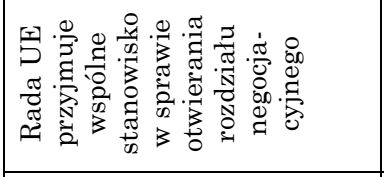 & $N$ & 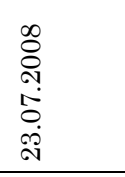 & 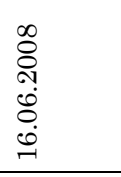 & 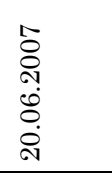 \\
\hline & 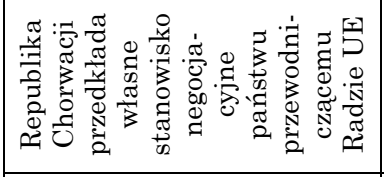 & 0 & 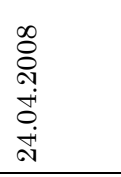 & 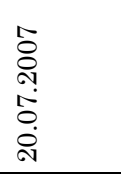 & 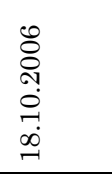 \\
\hline & 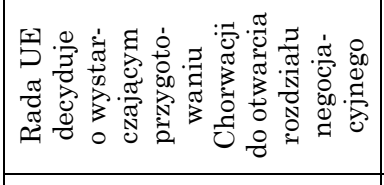 & 20 & 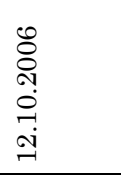 & 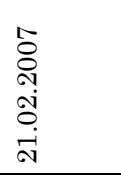 & 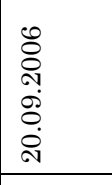 \\
\hline & 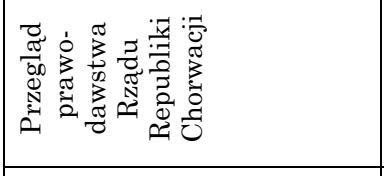 & $\forall$ & 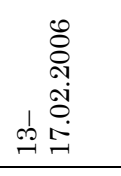 & 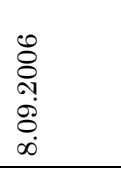 & 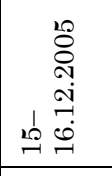 \\
\hline & 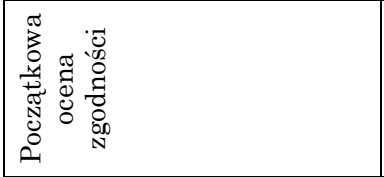 & $\infty$ & 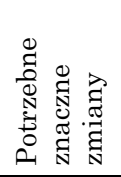 & 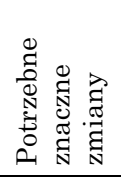 & 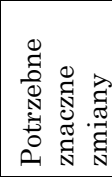 \\
\hline & 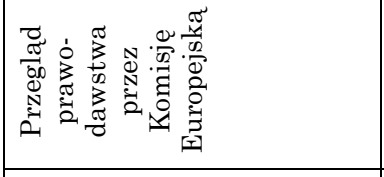 & $\sim$ & 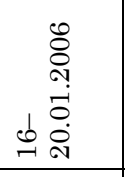 & 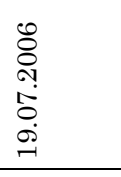 & 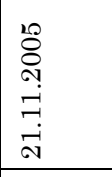 \\
\hline & 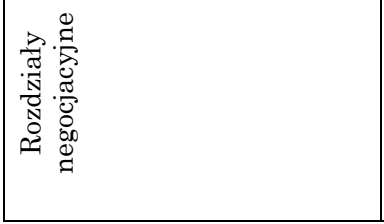 & & 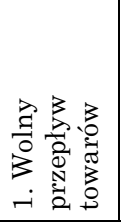 & 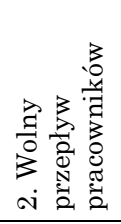 & 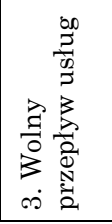 \\
\hline
\end{tabular}




\begin{tabular}{|c|c|c|c|c|c|c|c|}
\hline$\sigma$ & $\begin{array}{l}\circ \\
\stackrel{-}{\circ} \\
\text { Nุ } \\
\stackrel{-}{-1} \\
10\end{array}$ & \begin{tabular}{l}
0 \\
0 \\
0 \\
\multirow{2}{0}{} \\
0 \\
0 \\
$\dot{0}$
\end{tabular} & 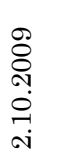 & 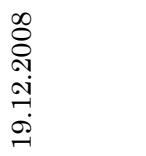 & $\begin{array}{l}-1 \\
ت \\
\circ \\
-1 \\
0 \\
0 \\
0 \\
0\end{array}$ & 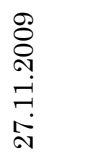 & 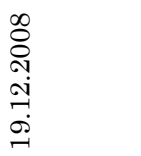 \\
\hline$\infty$ & 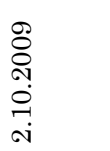 & 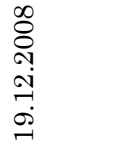 & 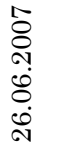 & 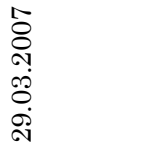 & 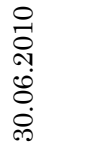 & $\begin{array}{l}5 \\
8 \\
\circ \\
\dot{0} \\
0 \\
\dot{0} \\
\text { ․ }\end{array}$ & 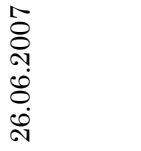 \\
\hline$N$ & 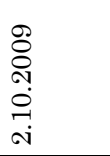 & 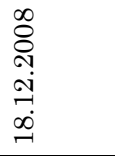 & 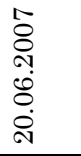 & 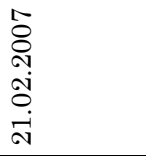 & $\begin{array}{l}0 \\
0 \\
\circ \\
0 \\
0 \\
0 \\
\stackrel{0}{N}\end{array}$ & $\begin{array}{l}5 \\
8 \\
\circ \\
\dot{0} \\
0 \\
\dot{0}\end{array}$ & 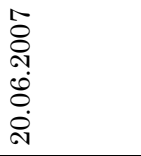 \\
\hline 0 & \begin{tabular}{l}
$\infty$ \\
0 \\
$\circ$ \\
\multirow{2}{*}{} \\
$\dot{0}$ \\
0 \\
10
\end{tabular} & 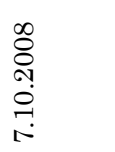 & 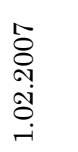 & 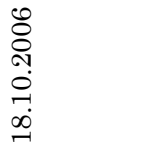 & $\begin{array}{l}\circ \\
\stackrel{1}{0} \\
\text { N̦ } \\
\text { ல } \\
\text { ì }\end{array}$ & 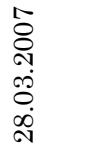 & $\begin{array}{l}5 \\
0 \\
\circ \\
\text { ọ } \\
0 \\
0\end{array}$ \\
\hline 10 & 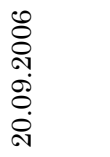 & 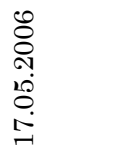 & 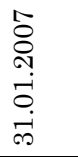 & 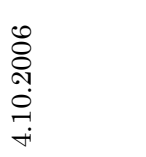 & $\begin{array}{l}0 \\
8 \\
\circ \\
0 \\
0 \\
0 \\
\infty \\
\text { N }\end{array}$ & 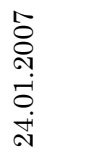 & 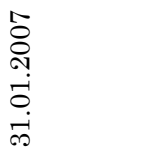 \\
\hline+ & 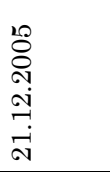 & 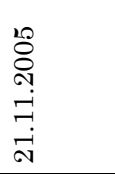 & 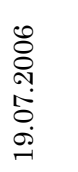 & 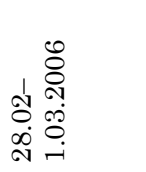 & 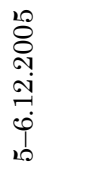 & $\begin{array}{l}0 \\
8 \\
\circ \\
-1 \\
10 \\
0 \\
10 \\
1 \\
1\end{array}$ & 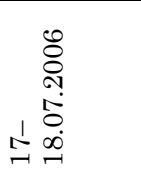 \\
\hline$\infty$ & 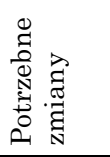 & 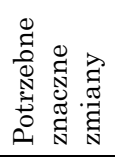 & 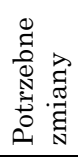 & 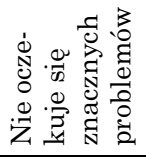 & 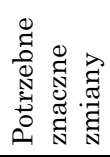 & 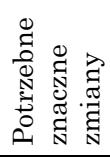 & 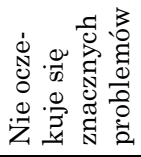 \\
\hline N & 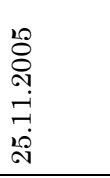 & 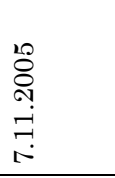 & 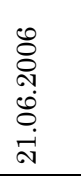 & 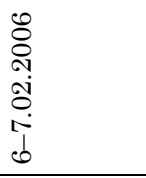 & 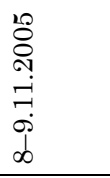 & 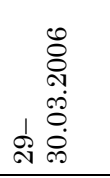 & 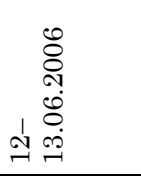 \\
\hline-1 & 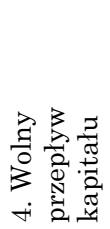 & 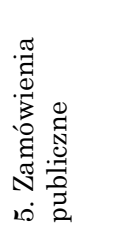 & $\begin{array}{l}\frac{1}{0} \\
\frac{0}{0} \\
0 \\
01 \\
0 \\
0 \\
0 \\
01 \\
0 \\
0 \\
0\end{array}$ & 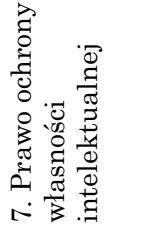 & 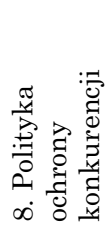 & 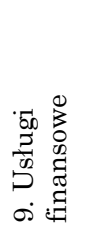 & 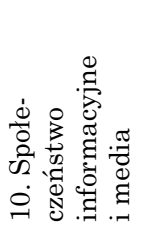 \\
\hline
\end{tabular}




\begin{tabular}{|c|c|c|c|c|c|c|c|}
\hline$\sigma$ & 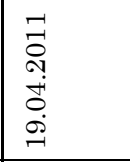 & 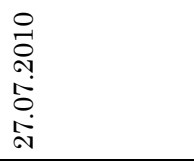 & 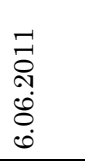 & 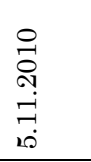 & 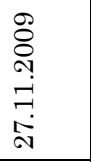 & 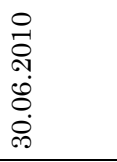 & 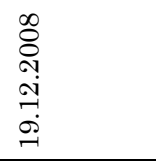 \\
\hline$\infty$ & 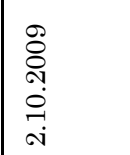 & 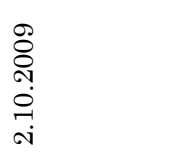 & 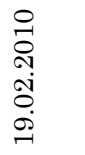 & 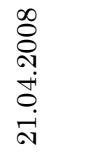 & 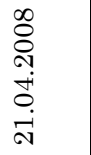 & 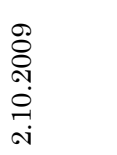 & $\begin{array}{l}8 \\
\& \\
\stackrel{\leftrightarrow}{N} \\
\text { I } \\
\stackrel{-}{-1}\end{array}$ \\
\hline$\sim$ & 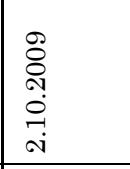 & 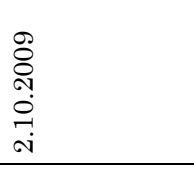 & 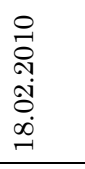 & 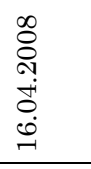 & 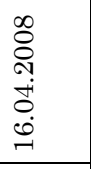 & 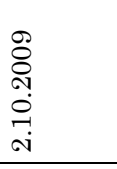 & 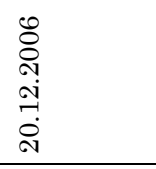 \\
\hline 0 & 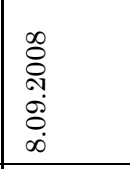 & 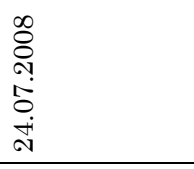 & 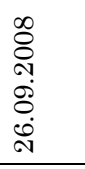 & 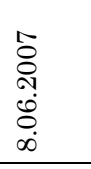 & 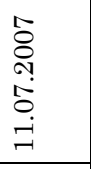 & 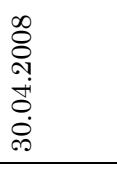 & 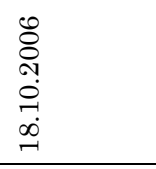 \\
\hline 10 & 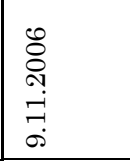 & 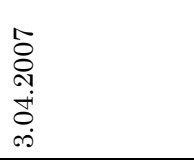 & 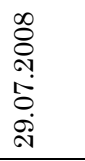 & 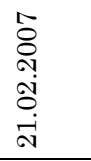 & 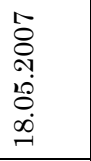 & 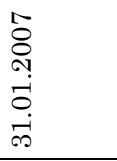 & 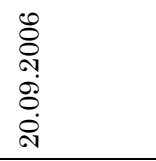 \\
\hline 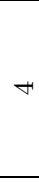 & 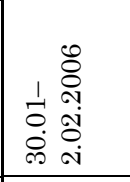 & 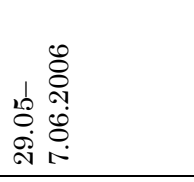 & 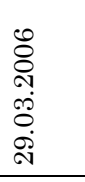 & 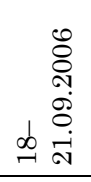 & 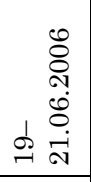 & 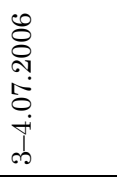 & 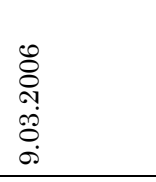 \\
\hline$\infty$ & 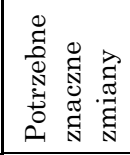 & 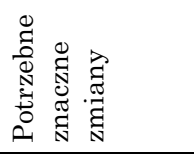 & 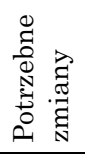 & 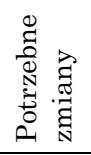 & 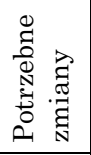 & 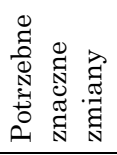 & 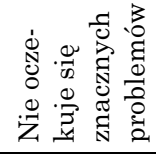 \\
\hline$\sim$ & $\begin{array}{l}10 \\
0 \\
0 \\
N \\
01 \\
7 \\
0 \\
1 \\
10 \\
\end{array}$ & $\begin{array}{l}0 \\
0 \\
0 \\
0 \\
0 \\
0 \\
0 \\
0 \\
0\end{array}$ & 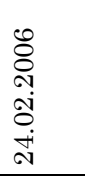 & 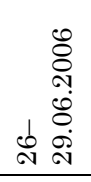 & 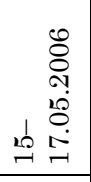 & 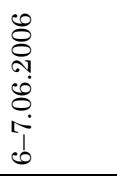 & 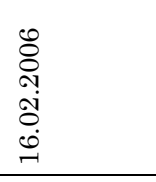 \\
\hline & 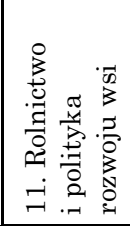 & 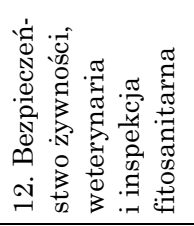 & 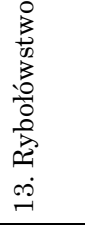 & 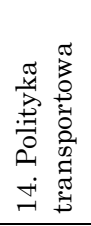 & 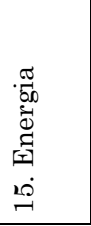 & $\begin{array}{l}\frac{1}{17} \\
\frac{\pi}{0} \\
0 \\
0 \\
0 \\
0 \\
-1\end{array}$ & 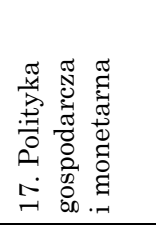 \\
\hline
\end{tabular}




\begin{tabular}{|c|c|c|c|c|c|c|}
\hline$\sigma$ & 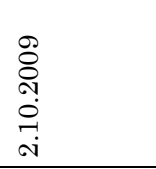 & 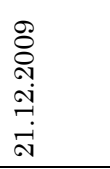 & 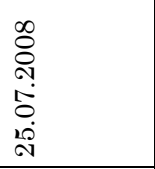 & 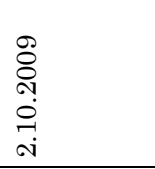 & 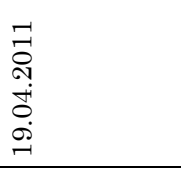 & 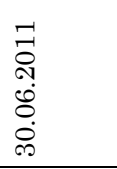 \\
\hline$\infty$ & 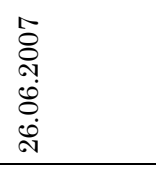 & 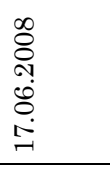 & 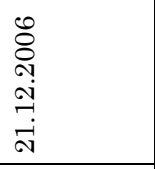 & 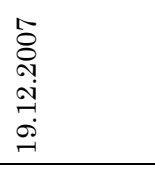 & 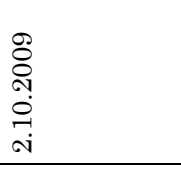 & $\begin{array}{l}\circ \\
\stackrel{1}{0} \\
\text {. } \\
\dot{0} \\
0 \\
\dot{0} \\
\infty\end{array}$ \\
\hline$\sim$ & 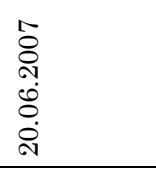 & 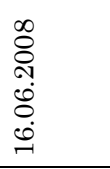 & 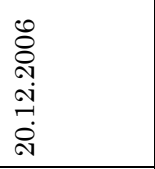 & 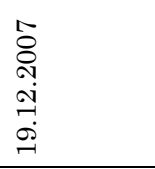 & 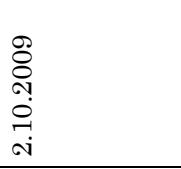 & 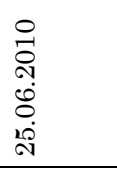 \\
\hline 0 & 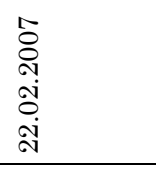 & 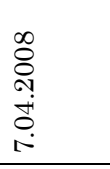 & 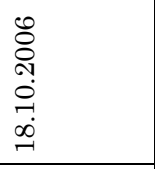 & 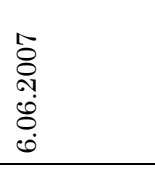 & 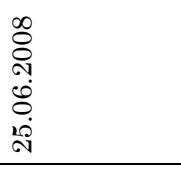 & 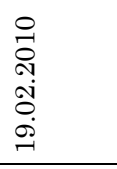 \\
\hline 10 & 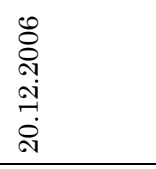 & $\begin{array}{l}0 \\
8 \\
0 \\
0 \\
5 \\
0 \\
\infty \\
0 \\
-1 \\
\end{array}$ & 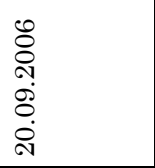 & 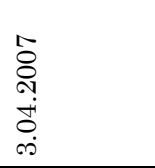 & 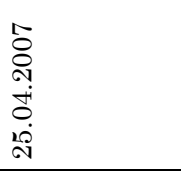 & 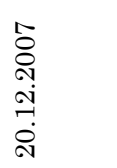 \\
\hline 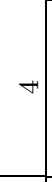 & 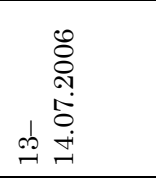 & $\begin{array}{l}0 \\
0 \\
0 \\
\infty \\
0 \\
0 \\
\infty \\
0 \\
0\end{array}$ & 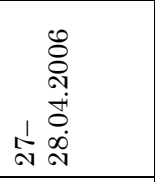 & 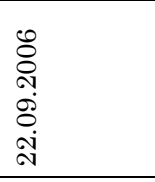 & 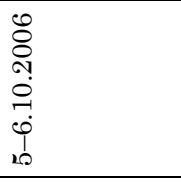 & 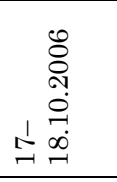 \\
\hline$\infty$ & 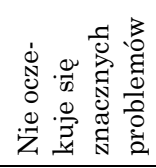 & 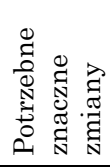 & 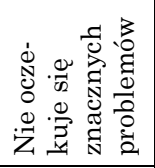 & 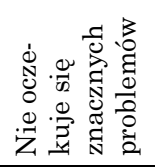 & 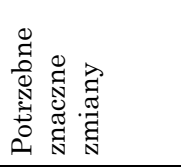 & 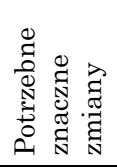 \\
\hline$\sim$ & 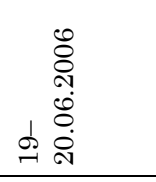 & 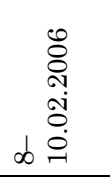 & 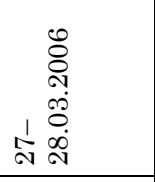 & 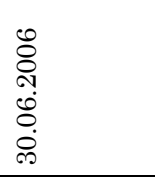 & 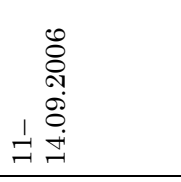 & $\begin{array}{l}0 \\
8 \\
0 \\
0 \\
0 \\
0 \\
0 \\
0 \\
0\end{array}$ \\
\hline-1 & 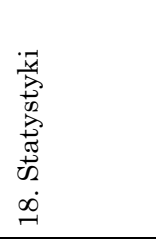 & 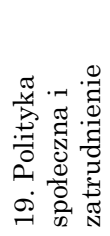 & 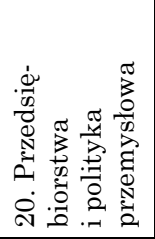 & 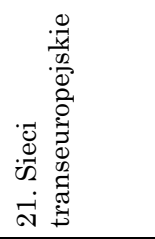 & 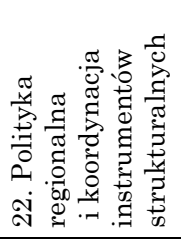 & 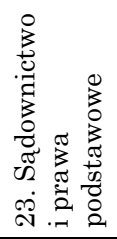 \\
\hline
\end{tabular}




\begin{tabular}{|c|c|c|c|c|c|c|}
\hline$\sigma$ & 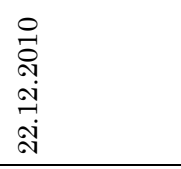 & 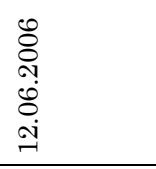 & 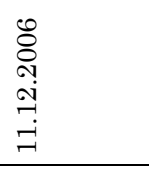 & 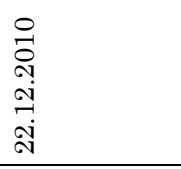 & 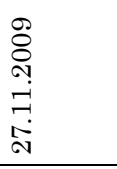 & 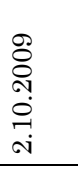 \\
\hline$\infty$ & 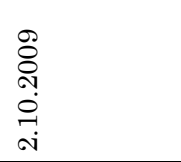 & 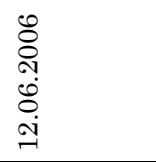 & 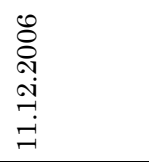 & 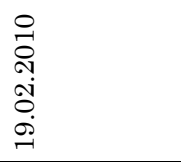 & 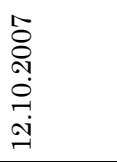 & 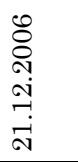 \\
\hline$\sim$ & 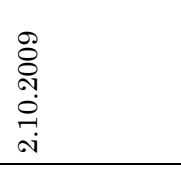 & 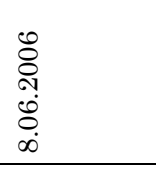 & 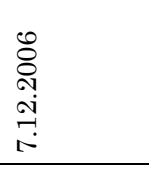 & $\begin{array}{l}0 \\
\stackrel{1}{0} \\
\stackrel{0}{1} \\
\text { ò } \\
0 \\
\infty \\
-\end{array}$ & 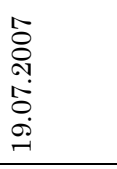 & 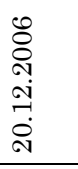 \\
\hline 0 & 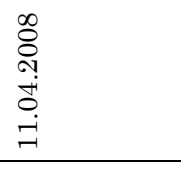 & 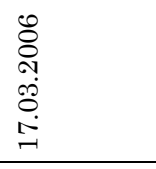 & 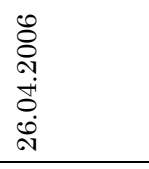 & 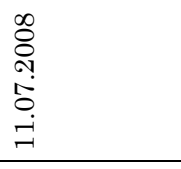 & 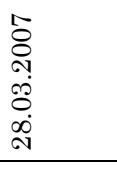 & 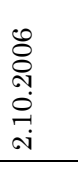 \\
\hline 10 & 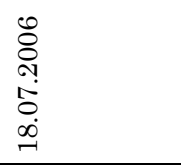 & 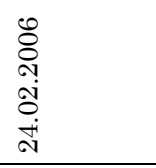 & 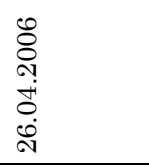 & 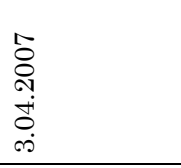 & 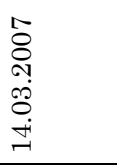 & 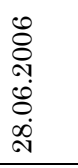 \\
\hline 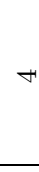 & 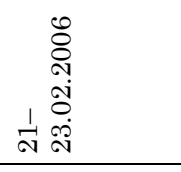 & 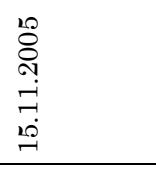 & 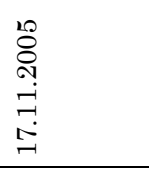 & 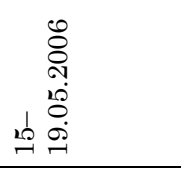 & 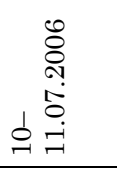 & 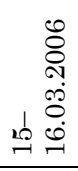 \\
\hline$\infty$ & 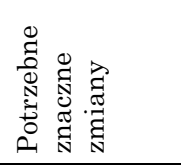 & 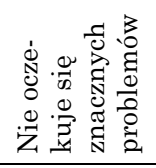 & 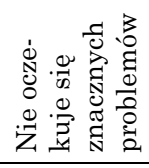 & 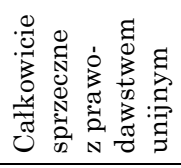 & 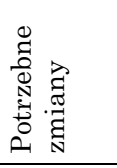 & 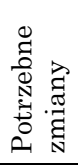 \\
\hline N & 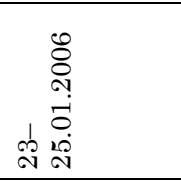 & 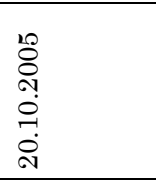 & $\begin{array}{l}20 \\
0 \\
0 \\
0 \\
0 \\
-1 \\
0 \\
0\end{array}$ & 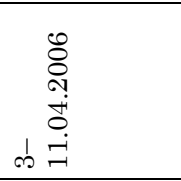 & 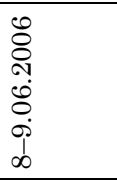 & 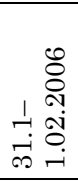 \\
\hline- & 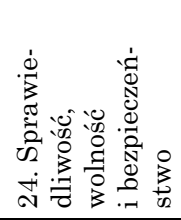 & 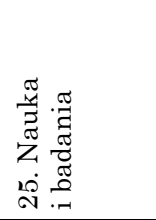 & 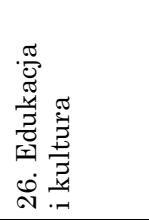 & 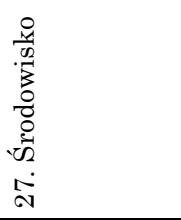 & 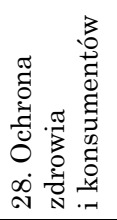 & 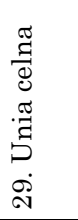 \\
\hline
\end{tabular}




\begin{tabular}{|c|c|c|c|c|c|c|}
\hline$\sigma$ & 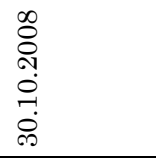 & 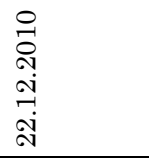 & 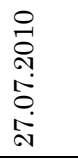 & 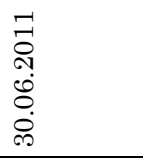 & $\begin{array}{l}\stackrel{0}{\circ} \\
\stackrel{\circ}{\oplus} \\
\stackrel{-1}{10}\end{array}$ & 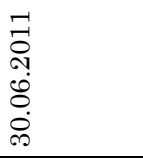 \\
\hline$\infty$ & 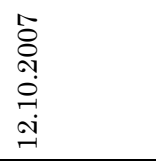 & $\begin{array}{l}0 \\
\stackrel{1}{1} \\
\text {. } \\
\dot{0} \\
\dot{0} \\
\dot{\infty}\end{array}$ & 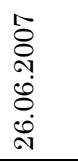 & 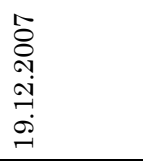 & $\begin{array}{l}\stackrel{0}{1} \\
\stackrel{\circ}{\circ} \\
\stackrel{-1}{-1} \\
10 \\
\end{array}$ & 1 \\
\hline$\Lambda$ & 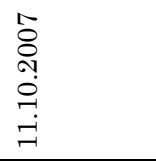 & 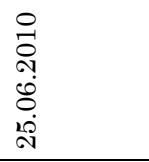 & 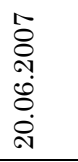 & 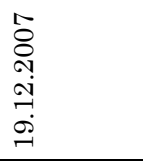 & 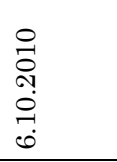 & 1 \\
\hline 0 & 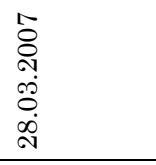 & 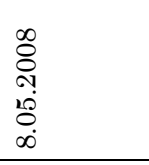 & 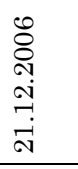 & 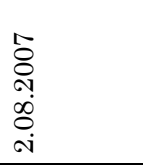 & 1 & 1 \\
\hline 10 & 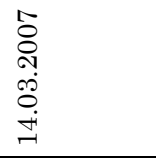 & 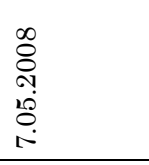 & 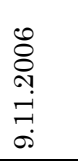 & 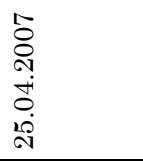 & 1 & 1 \\
\hline$\nabla$ & 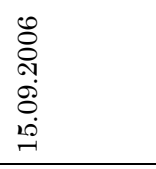 & 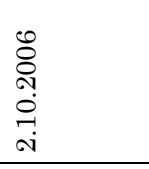 & 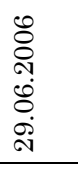 & 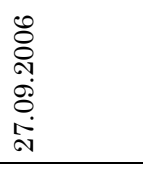 & 1 & 1 \\
\hline$\infty$ & 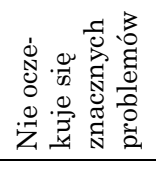 & 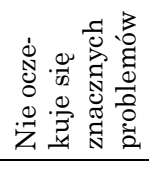 & 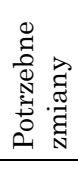 & 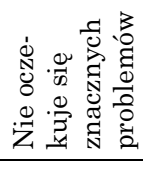 & 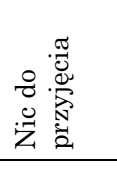 & 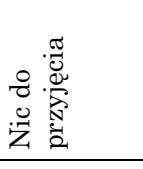 \\
\hline$\sim$ & 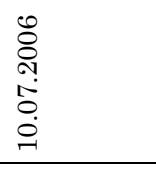 & 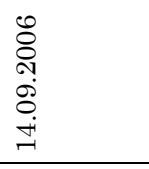 & 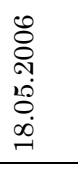 & $\begin{array}{l}0 \\
0 \\
\circ \\
\text { ọ } \\
0 \\
0 \\
0 \\
\end{array}$ & 1 & 1 \\
\hline-1 & 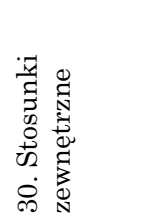 & 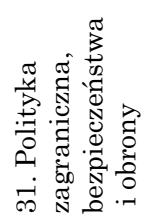 & 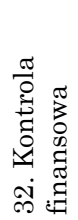 & 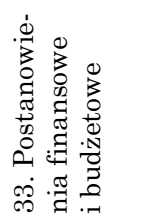 & 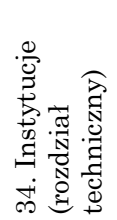 & 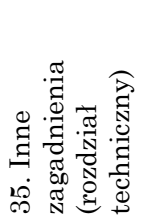 \\
\hline
\end{tabular}




\section{Załącznik 3}

Programy Unii Europejskiej, w których uczestniczy Chorwacja

Chorwacja jako państwo kandydujące uczestniczyła w 2011 r. w następujacych programach UE:

- Siódmy Ramowy Program Badań

- Ramowy Program Konkurencyjności i Innowacji

- Postęp

- Kultura

- Europa dla Obywateli

- Fiscalis 2013

- Cła 2013

- Instrument Finansowy Ochrony Obywatelskiej

- MEDIA 2007

- Działanie wspólnoty w obszarze zdrowia

- Marco Polo II

- Mechanizm Ochrony Obywatelskiej

- Nauka przez całe życie, młodzież w akcji

- ISA - Interoperacyjny Program Rozwiąań dla Administracji Publicznej.

\section{Załącznik 4}

Chorwaccy przywódcy w latach 1991-2011

\section{Prezydenci Chorwacji}

1990-1999 Franjo Tuđman

1999-2000 Vlatko Pavletić, Zlatko Tomčić (tymczasowo, po śmierci Tuđmana)

2000-2010 Stjepan (Stipe) Mesić

2010- Ivo Josipović 


\section{Premierzy Chorwacji}

1990

Stjepan (Stipe) Mesić

1990-1991 Josip Manolić

1991-1992 Franjo Gregurić

1992-1993 Hrvoje Šarinić

1993-1995 Nikica Valentić

1995-2000 Zlatko Mateša

2000-2003 Ivica Račan

2003-2009 Ivo Sanader

2009-2011 Jadranka Kosor

2011-

Zoran Milanović 


\section{Contents}

Introduction by His Excellency Ambassador of Republic of Croatia in Poland ........................................................... 93

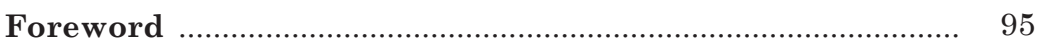

Chapter I

Croatia yesterday and today ................................................... 101

Chapter II

Croatian path to the European Union ....................................... 109

Chapter III

Croatia in the European Union ................................................ 123

Institutional aspects .................................................................. 123

The European Council ...................................................... 126

The Council of the European Union ...................................... 126

The European Parliament ....................................................... 129

The European Commission .................................................. 129

Croats in other institutions of the European Union ............... 130

Economic and financial aspects ..................................................... 130

Budget of the European Union ............................................... 130

The Common Agricultural Policy .............................................. 133

Cohesion policy …........................................................... 137

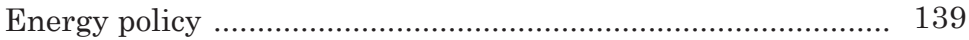

Climate policy ................................................................... 141

Cooperation in the area of the foreign policy ................................ 142

Challenges for Croatia .................................................................. 144

Chapter IV

Conclusions for Poland ............................................................ 149

Bibliography indications ........................................................ 153 
92

\section{Appendix:}

1. Chronology of integration of Croatian with the European Union

2. Table of negotiations of particular chapters ........................ 169

3. EU Programmes, in which Croatia participates ................... 175

4. Croatian leaders between 1991 and 2011 ........................... 175 


\section{Introduction by His Excellency Ambassador of Republic of Croatia in Poland}

Our country faces realizing one of the key priorities of the foreign policy and achieving its fundamental aim, which is full membership in the European Union, core of permanent peace, democratic values, economic development and social welfare.

During years of negotiation process Croatian society had to undergo profound change, not only in a sense of adjusting legislation through adopting acquis communitaire, but more importantly, due to complex reform of various sectors. We make continuous efforts aiming at creating efficient system of justice and functional state of law, efficient administration, fulfilling conditions of functioning competitive market, at the same time adopting policy of zero tolerance for corruption. As to further reforms there is both political agreement and full commitment of all the adequate social factors.

We are especially glad that we will sign the accession treaty exactly during the Polish presidency in the Union. This way we will deepen all the dimensions of our bilateral relations and strengthen friendly bonds between us, which are rooted far in the past. We will add new meaning to them, this time in the context of cooperation within the European Union.

Croatia understands European Ideas as community of European nations and states building future based on common values and rules, at the same time keeping state, national, political, cultural and economic differences. 
System of values of the EU expresses interests of Croatian state and society the best way, these values will be efficiently protected exactly thanks to full participation in the process of the European integration. Analysis of costs and benefits of joining the Union shows that in a long run Croatia will benefit from membership in the EU. It is estimated that potential economic, political, scientific-cultural and general development of the Republic of Croatia is bigger within than outside of the Union*.

I am convinced that Croatian citizens will realize that and that the outcome of referendum concerning joining the European Union by Croatia will be positive, which is proved by the public opinion polls, showing constant support for the Union.

I am very glad that such publication was prepared during the Polish presidency. It will contribute to better understanding of both negotiation process and accession of Croatia to the EU, as well as to realizing potential beneficial cooperation between Poland and Croatia on the European Union's forum.

Ivan Del Vechio Ambassador of the Republic of Croatia to Poland

Warsaw, November 2011

${ }^{*}$ From Editors: after submitting text for publication, on January 22, 2012 , over $66 \%$ of Croats voting in referendum voted in favour of a accession to the EU (witch attendance reaching $43,5 \%$ ). 


\section{Foreword}

Research Centre of the University of Lodz "Balkans at the turn of the 20th and the 21st century" is pleased to present Readers with a publication edited by Jan Muś and Marta Szpala, introducing general knowledge concerning position of Croatia on the doorstep of its membership in the European Union.

Grammatical form of the Future Perfect tense in the title of this kind of guide is not only projection of expected occurrences, it is also a proof of kindness and sympathy for the society of this state. These two virtues commands appreciating Croatian efforts in reference to changes happening in internal administration, normalization of the relations with the neighbours (with the closest ones, with further ones problems were observed more rarely) and finally putting more emphasis on implementation of solutions functioning in tradition of the West.

It is impossible to disregard efforts in this area made after the year 1999, positively verified by the European Commission in published in 2004 avis concerning application for membership in the Union, more specified in the Negotiation Framework created a year later. Accession process at the stage of agreeing on rules and principles as well as realization of the preliminary program was heavily influenced by the reluctance of Zagreb towards real cooperation with the International Criminal Tribunal for the former Yugoslavia and too slow pace of normalization of relations with "near abroad" - especially with Serbia. 
Concessions forced on the government by factors in Brussels, in favour of Hague - especially in the first segment of the issues, allowed to reach an agreement on negotiations procedures and rapprochement of the sides concerning schedule of works in Autumn 2005. It has to be pointed out that important role in the process of changes and overcoming results of the war in the former Yugoslavia, including inflicted losses, was played by invitation Croatia (together with Albania) to join the North Atlantic Alliance at the summit in Bucharest in 2008 which resulted in both states becoming members of NATO at the beginning of April following year.

Undertakings of colourful government under Ivo Sanader seemed to contribute to realization of strategic aim - accelerating process of integration with the Union, in the situation of weakening economic condition of the country. Wide and quite extraordinary for this region coalition became more active in the areas of regional and national policy, it was not able, however, to stop increasing crisis, what is worse - in spite of spectacular gestures, it lacked willingness and decisiveness to oppose organized crime, omnipresent corruption and present conciliation attitude in relations with Slovenia.

Success of this period includes infrastructural investments such as building network of modern highways, overtaking many Union's member states modernization of railways, introduction of sensible regulations in the sector of healthcare and welfare. Problems included issues connected with the system of justice, such as inefficient attempts at reforms of judiciary, lack of arbitrage institutions, excessive influence on settlements of disputes and sentences concerning economy in reference to oligarchs and people connected with the party's and military's establishment. Bearing in mind promotional character of this publication, this introduction should include conviction that these faults manifesting themselves in the public life also 
nowadays, will be easier to fight within aggregation of 28 members.

It would be a simplification of this problem to reduce it to discussion about placing judiciary among leaders of corruption or using judiciary in a very selective manner. Courts and prosecutor belong to these Croatian institutions, in which there are, since the first elections lost by HDZ (Croatian Democratic Union) in January 2000, crucial, although not very consequently realized changes. Violation of judicial ethics or fabrication of legal documents (for example as a result of strong political pressure on the judges and their decisions), earlier notorious, nowadays are more rarely observed.

Progress made by Croatia on the way to the Union allows to believe in projection of a better condition of law or - how Croatian President of the Supreme Court said - "depoliticizing courts and turning them into real third power". Its state, as it was a decade ago, remains "complex" but contrary to then, there are views for improvement. For now on, keeping in mind perturbations connected with "opening balance" in the "new" Union's members, we have to come to terms with the fact that Croatia will join the Union having at its disposal (at least for some time) standards in power for example in some of the successors of the former Soviet republics "East from Kiev".

The European Union sets framework and desired directions of policy, its general aims and development assumptions. It does not impose "fixed" solutions on the member states. On the other hand, it does not mean that joining the transeuropean alliance will not generate need for taking into consideration Brussels' recommendations and decisions, but it does let policy of Croatia, as in case of any other state, formulate its own development assumptions and determining ways of realizing them.

Vast majority of society over Sava River and Adriatic Sea is aware of the fact that next to benefits from the 
membership in the EU, rule of law and respect for law as well as social welfare are conditions for improving the level of life and better perspectives. They also know that fundamental rule of social morality should be defined by priority of duties towards other people, not towards central or local oligarchs, regardless of their resurrection contributions.

Friends of the Southern Slavic nations, including obviously their Western rims, want to believe that hierarchy of servitude and public utility will soon determine gradation of the social positions. It will let withdrawing concession for division of the Republic into spheres of influence, and fight against social pathologies, development, including reasonable management of resources, will become elements of modernly understood national security replacing creating psychosis of threat posed by the neighbours.

To paraphrase words of outstanding humanist, Tadeusz Kotarbiński, let's try to see this Croatia which it might become in the close future, not necessarily this one which we see today. Instead of supporting skeptics discussing chances for "independent courts and free media", it is better to keep record of our Polish (even though resulting not only from the presidency, during which accession treaty was signed on December 9,2011) support for right aspirations of Croatia - positives. Example of right direction of change process is leaving the electoral engineering, notoriously used in the first "decade of freedom" in shape of manipulations in law, joining powerful oppositional constituencies with the ones which strongly support ruling party, resigning from a function of list exponent, that is to say a person de facto not running in the elections and so on. Entail already from 2006 reduced possibilities of malpractice such as manipulating votes of diaspora, using "double" option, and the end of decade let the local governments strengthen. In case of historical politics, contrary to his predecessors, president Ivo 
Josipović is far from praising Pavelić's state, and it does not come to mind of the Sabor's speakers to, as the former president of the parliament from the first half of the 90s did, refer from the parliament's platform to "noble features of fascism". Can we refuse Union's remedy to society tired of resentments and "official" demagogy, creating home-grown tacoons connected with the government, affairs atop?

It should be remembered that Croats absorbed in their difficult history and adapted to their own conditions values of European culture and national elites were shaped under influence of various modern traditions of philosophy, science and art. They enriched Enlightenment thought and ideas of Romanticism, Positivism, slogans of liberalism or occurrences of industrial revolution and progress in science and technology. Ethnic community, which at start of its independence was dramatically deprived of its own sovereignty, sentenced to attempts of its restitution, sometimes heroically, sometimes completely in vain, rooted in the European intellectual heritage, praising ideas of Catholicism, independence and family.

Integration provides Croats with better economic perspectives and development possibilities - including benefiting from achievements of better developed countries. Transeuropean space, regardless of any turbulences, creates conditions for improvement of existence, carrying out structural reforms, benefiting from Community's financial instruments. Membership does not limit national diversity or realization of basic values of reason of state, connecting - which in this case is of fundamental importance - subjects of process in respect for democracy, rule of law, free market and human rights. Membership in this order is not as such panacea for dealing with problems of identity, megalomania and xenophobia, blown out of proportion factionalism, excitability or emotionalism, it helps, however, to put a halt to all these faults. Together 
with latest attempts aiming at social-political changes as well as meeting the challenges of accession, it lays ground for the Treaty, its ratification in member states (and in Zagreb) and joining the European Union by the Republic of Croatia on July 1, 2013.

Professor Wiestaw Walkiewicz* President of the Scientific Council Research Centre "Balkans at the turn of the $20^{\text {th }}$ and the $21^{\text {st }}$ century"

Lodz-Warsaw, December 2011

* Ambassador of the Republic of Poland to Croatia between 1993 and 1997. 


\section{Chapter I \\ Croatia yesterday and today}

Contemporary Croatia is in many ways similar to Poland - it has to face numerous similar social, political or economic problems typical of the states in the era of transformation. Specific historical background resulted in a few crucial differences that have to be underlined.

Medieval Croatia was dominated by the Hungarian neighbours relatively soon, first by the country of the Arpads, then it was incorporated by the Habsburg monarchy. National identity of the Croats was taking shape in reaction to the fight against magyarization, but also an armed struggle against the Ottoman Empire. Awakening of the national consciousness of the Southern Slavs in the $19^{\text {th }}$ century led to presenting various suggestions concerning shape of the future of the Croatian state. Some of them postulated creating the third, Slavic part of the monarchy consisting of Austria and Hungary so far. Other suggestions put more emphasis on creating independent Croatian state. The movement which aimed at uniting Southern Slavs in one state gained big popularity. What is different between Poland and Croatia is division of the Slavic nations inhabiting the peninsula into Catholic West and Orthodox East. Ethnic mosaic of the territories now known as Croatia as well as neighbouring Bosnia and Herzegovina, Montenegro and Serbia made it impossible to create strong and at the same time homogenous national states. On the other hand 
ethnic proximity of the Southern Slavs resulted in hope with which the idea of future common state was perceived. Uniting Slavic territories into one political entity would let Orthodox Serbs inhabiting Croatia or Catholic Croats in Bosnia and Herzegovina stay within the borders of the country which they could perceive as their own.

Kingdom of Serbs, Croats and Slovenes, as the Yugoslav monarchy was officially called until 1929 , did not stand the hard test of the interwar period. It is hard to say who or which side takes the responsibility for such an outcome. It is a fact though that the central line of the conflict was between Serbian centralists and Croatian autonomists. With time this conflict took more harsh forms, including murder of the Croatian leader Stjepan Radić in the Yugoslav parliament in 1928, introducing authoritarian government and assassination of Yugoslav king Alexander I Karađorđević in 1934. However, it is worth mentioning agreement from August 1939, as a result of which Croatia received wider autonomy within Yugoslav state ${ }^{1}$.

Negative experiences of cooperation with Belgrade in the 20s and 30s pushed Croats into the arms of the Axis countries. It led to a tragedy that took place during the World War II on the territories of Croatia, Bosnia and Herzegovina and Serbia, where army of Croatian fascists - the Ustaša - committed crimes against both non-Croatian and Croatian oppositionists. International character of the winning guerilla movement of Marshal Tito, which consisted also of Croats, meant that new post-war state, even though of a totalitarian character will take into consideration specific character of multinational Yugoslavia and will give up centralism which dominated in times of so-called first Yugoslavia.

The Socialist Federal Republic of Yugoslavia indeed united and temporary reconciled formerly conflicted sides

${ }^{1}$ It was so-called Cvetković-Maček agreement, Banovina of Croatia was created then, it functioned only until outburst of war in April 1941. 
under the banner of one-party system. Yugoslavia had positive connotations in Poland not only thanks to Yugoslavs, but also thanks to welfare and material glimmer, which was missing so much in the times of the People's Republic of Poland. Spending time in Dalmatia it was possible to feel the Western climate staying at the same time among people similar to Poles more than French, Italians or Germans.

This kind of Yugoslav dream, and looking from the global perspective it might be called also a paradox, was possible thanks to two factors. First, Yugoslavia, willingly or not, found itself between the Eastern Communist and Western, capitalist blocs ${ }^{2}$. Marshal Tito, together with the presidents of Indonesia, Sukarno, Egypt - Naser and of India - Nehru, created so-called Non-Aligned Movement ${ }^{3}$, which was supposed to stay aside at the ongoing Cold War. It let the members keep relative independence from powerful empires and play the differences between the blocs for their own benefit. Subsidies, credits and loans from the Western world were supposed to keep the safe distance between Yugoslavia and Moscow. Non-Aligned Movement involving practically whole Africa, Latin America and majority of the Southern-Eastern Asia, led to increasing the volume of trade from Yugoslavia to for example African and Arabic countries. Collapse of these markets in the $70 \mathrm{~s}$ forced Yugoslavia to reorient itself to the West. This way Croatia and Slovenia gained much more importance. In Croatia the wave of 'currency' tourists from the West was

${ }^{2}$ It is worth to remember that Yugoslavia until 1948 was called „satellite number one" of the USSR, but as a result of conflict with Moscow it was discarded from Cominform and started functioning outside the bloc of countries subordinate to USRR.

${ }^{3}$ Currently it has 118 member states, and 18 countries and 10 organizations with the status of observatory, including Bosnia and Herzegovina, Croatia, Montenegro and Serbia. http://www.namegypt. org/en/AboutName/MembersObserversAndGuests/Pages/default.aspx. 
especially visible, from the beginning of the 70s they kept massively coming to the Adriatic coast.

The second factor consisted of economic liberalization as well as administrative and to some extent also political decentralization of the country. It enabled republics such as Croatia or Slovenia to achieve rapid and permanent economic growth, and as a consequence improve the level of life in the poor South of the country. Local government's system of production, approved already in the 50s and then further developed, brought about outstanding effects for a long time, making the production more flexible and as a result more sensitive to changes and needs of the markets, which could not be said about for example planned economy of the People's Republic of Poland. Death of Marshal Tito and the end of the Cold War enforced political liberalization and deepening differences in the economic development of individual republics and taking over the power by the nationalist led to serious conflict between leaders of the republics and as a consequence to war and dissolution of Yugoslavia.

Tragedy of dissolution of the former Yugoslavia came as a surprise to a majority of the world, role and input of the republics and its leaders, including Croatia and its president in this time Francjo Tudman remain until now the subject of a discussion. Did Croatian Serbs together with Milošević provoke a harsh contraction of the authorities in Zagreb? Or maybe it was nationalist rhetoric of Tudman that led to increasing distrust between these two groups? What role did Croatia play during the war in Bosnia and Herzegovina? Did it keep relative neutrality? Or was it one of the fighting sides? Did Croatian army commit crimes against Serbian and Bosnian civilians? What was the course of action within operation "Storm", which ended independent being of the Serbian territory within Croatian borders in $1995 ?^{4}$ Should Tudman and other leaders from

${ }^{4}$ With an exception of so-called Eastern Slavonia, which was back under control of Zagreb in 1998. 
the war period be condemned or they are national heroes fathers of Croatian independence?

These and other questions divide Croatian society and Croatian political stage until now. The process of democratization itself ended quite late, no sooner than in the years 2000-2001, after Tudman's death and change into ruling the country from authoritarian to democratic. Paradoxically transformation took relatively long because of the lack of opposition against the system. Relative economic welfare and relatively liberal political system, especially comparing to Eastern bloc's countries such as Bulgaria, Romania or Albania, did not encourage shaping wide opposition elites, as it happened in Poland, Czechoslovakia or Hungary. Almost in whole Yugoslavia Communist elites exceptionally often were wearing a mask of nationalism, which gained much popularity, given all the ethnic differences. Removal the team of Tudman from power should be seen as opening the doors to the European Union.

Current political system became a stage for fights between two main political groups - social democratic SDP (Socijaldemokratska Partija Hrvatske) and Christian Democratic HDZ (Hrvatska Demokratska Zajednica). Both theses parties, similarly to $\mathrm{w}$ few smaller ones who also have their representatives ${ }^{5}$ in Croatian parliament - Sabor,

${ }^{5}$ Central: the Croatian People's Party - Liberal Democrats (Hrvatska narodna stranka - Liberalni demokrati - Hrvatska seljačka stranka, HNS-LD), the Croatian Peasant Party (Hrvatska seljačka stranka, HSS); Right-wing the Croatian Party of Rights (Hrvatska stranka prava, HSP); Left-wing: the Croatian Party of Pensioners (Hrvatska stranka umirovljenika, HSU), Croatian Social Democrats (Hrvatski socijaldemokrati), Croatian Labourists - Labour Party (Hrvatski laburisti - Stranka rada, HL-SR); Regional: Croatian Democratic Alliance of Slavonia and Baranja (Hrvatski demokratski savez Slavonije $i$ Baranije, HDSSB), Istrian Democratic Assembly (Istarski demokratski sabor, IDS); Representing ethnic minorities: Independent Democratic Serb Party (Samostalna demokratska srpska stranka, SDSS), the Party of Democratic Action of Croatia (Stranka demokratske akcije Hrvatske, SDAH). 
support the integration of Croatia with the European Union. HDZ has been in power since 1990, with the exception of the years 1991-1992 when a government of national unity was created and the years 2000-2003 when Social Democrats from SDP took over the power ${ }^{6}$. In December 2011 the elections were won by oppositional and centre-left Kukuriku Coalition, whose strongest party is SDP.

The governmental system is stable with relatively well functioning administration, executive, head of state and one chamber parliament. Judiciary remains to be a problem, to be more specific - implementing legislation in line with European norms. Zagreb has to also face corruption and in wider scale excessive politicization of the public administration.

Croatia is quite small economy at an average level of development. Its GDP in 2010 reached 45.5 millions euro. GDP per capita in Croatia is higher than in a few member states of the European Union (Romania, Bulgaria, Lithuania and Latvia) and reaches 17.8 thousands USD. In 2008 it was $65 \%$ of the European Union's average. Economy is based mainly on the sector of services, whose part in GDP reaches $68.8 \%$. Share of industry is not big - 19\% of GDP, similarly to agriculture $-5.5 \%$ of GDP, construction sector gains importance, it adds up to $6.7 \%$ GDP.

Until 2008 Croatia reached growth on an average level of $4.7 \%$ GDP annually. Croatian state attracted the biggest number of investments among the states of the Western Balkans - in 2008 they reached 19 billion euro. Global economic crisis influenced the state economy very badly. GDP decreased significantly - 5.8\% in 2009, $1.5 \%$ in 2010. Foreign investments which until then stimulated growth also decreased by $11.8 \%$ in 2009 and $9.3 \%$ in 2010 . It resulted in difficulties in keeping the stability of the budget and increase in the budget deficit - 3.9\% in 2009

\footnotetext{
${ }^{6}$ See Apendix 4. Croatian leaders between 1991 and 2011.
} 
and $6.5 \%$ in 2010 . There was also a significant increase of unemployment, which in 2010 reached the level of $18.8 \%$ which as a consequence led to decrease in internal demand and caused long-lasting stagnation. It has to be underlined though that Croatia managed to survive the crisis without any external help from the International Monetary Fund or the European Union.

The main problem of the Croatian economy comes down to high dependence on so-called sensitive sectors, such as tourism, which generates around 20\% of GDP and to low level of industrialization, which leads to low volume of export and high deficit in the foreign trade. External debt is also on a very high level, it reaches $101 \%$ of GDP. Because of the high costs of labour and low efficiency the Croatian economy is also not very competitive comparing to for example countries of the Central Europe. Croatian government hopes that membership in the EU will make it possible to increase the volume of foreign investments and to accelerate the economic growth. Nonetheless it seems crucial to carry out structural reforms, which will improve competitiveness of the economy. Taking into account economic development and internal political reality Croatia is on a good way to complete domestic reforms and to gradually reinforce its international position, but this process requires further effort and the success is not sealed yet. 



\section{Chapter II}

\section{Croatian path to the European Union}

Croatian accession to the European Union, whose chronological course is presented in the appendix no. 1, was put into framework of the Stabilization and Association Process, an instrument set up in 1999 directed at all the states of the Western Balkans. It assumed gradual integration of the states from the region aspiring to membership in the EU through wide and at the same time deep cooperation as well as support of a number of economic, political and social reforms ${ }^{1}$.

The Europan Commission's opinion about Croatian membership in the EU says: „The European Council meeting in Copenhagen in June 1993 laid down the conditions for eligibility that guide the accession process and the Commission's regular assessments of Croatia's readiness for membership. The political criteria require Croatia to ensure the stability of institutions guaranteeing democracy,

${ }^{1}$ More about the Stabilization and Association Process on the European Commission's webpage: http://ec.europa.eu/enlargement/enlargement_process/accession_process/how_does_a_country_join_the_eu/ sap/index_pl.htm.Look. Also see: B. Górka-Winter, Polityka zewnętrzna UE wobec Batkanów Zachodnich - wniosek Chorwacji o przystapienie do UE, „Biuletyn PISM”, No 36 (140), 16 VI 2003; Batkany Zachodnie a integracja europejska. Perspektywy i implikacje [ed. by J. Muś and R. Sadowski], Urząd Komitetu Integracji Europejskiej, Ośrodek Studiów Wschodnich, Warszawa 2008. 
the rule of law, human rights and respect for and protection of minorities; these requirements are now enshrined in the Treaty on European Union and the Charter of Fundamental Rights of the European Union. The economic criteria require the existence of a functioning market economy as well as the capacity to cope with competitive pressure and market forces within the Union. The acquis criterion refers to the ability to take on the obligations of membership arising from the Treaties and the Union's legislation, the acquis, including the adherence to the aims of political, economic and monetary union. The Union's capacity to absorb new members, while maintaining the momentum of European integration, is also an important consideration in the general interest of both the Union and the candidate country"2.

The next important step took place in February 2003 when Croatia submitted an application for the membership in the European Union. This application was positively considered only in spring 2004 and in June the same year Croatia was granted a status of a candidate state.

A process of negotiations, started in October 2005, came across two significant challenges. First it was the good relations with neighbouring other former Yugoslav republics and second issue of cooperation with the International Criminal Tribunal for former Yugoslavia.

Taking into consideration bloody and violent process of dissolution of Yugoslavia the European Union put special emphasis on the stabilization of the situation in the Western Balkans' region. For Croatian membership in the European Union it was crucial to maintain correct relations with Serbia. In 1991 there was an open conflict between two republics which led to total rupture of official bilateral

${ }^{2}$ Commission Opinion on the application for accession to the European Union by the Republic of Croatia, European Commission, Brussels 12 X 2011, COM(2011) 667, http://ec.europa.eu/enlargement/ pdf/key_documents/2011/package/hr_opinion_2011_pl.pdf. 
relations. Nonetheless already in 1994 an agreement on normalization of mutual relations was signed. Since then there has been a constant improvement in the Serbian-Croatian relations. This tendency was also helped by the political changes which happened in both countries in the first years of the $21^{\text {st }}$ century. Death of Franjo Tudman and moving Slobodan Milošević from power helped both neighbours to get closer. An agreement on protection of national minorities was signed in 2004, in 2009 a number of agreements on fight against the organized crime and on economic cooperation was signed and in 2010 a military cooperation was set up. Mutual cases blaming another side for the course of action within the dissolution of Yugoslavia brought to the International Tribunal of Justice undoubtedly remain a bone of contention in Croatian-Serbian relations.

Relations between Bosnia and Herzegovina and Croatia were a bit different. The main reason for this state of matters was Croatian president Franjo Tudman's hostile attitude towards neighbouring republic. Since the democratic changes in Croatia relations Bosnian-Croatian improved significantly. A number of agreements on cooperation in criminal cases were signed and Croatian president Ivo Josipović, elected in 2010, did numerous gestures aiming at mutual forgiveness for the harms done during the war in Bosnia and in Croatia and at reconciliation between the nations that took part in them.

Croatia is a member of many regional multilateral initiatives, such as South-East European Cooperation Process, Central European Free Trade Agreement or Regional Cooperation Council. What is more, Croatian leaders meet leaders of Bosnia and Herzegovina, Montenegro and Serbia more and more often also apart from existing frameworks of the institutions ${ }^{3}$.

${ }^{3}$ One of such summits in 2005 resulted in adopting Saraievo's Declaration concerning cooperation on the issue of the refugees. 
Meanwhile in 2008 the escalation of the conflict between Slovenia and Croatia concerning the Gulf of Piran occured. In December 2008 Ljubljana blocked opening of the next chapter in negotiations - Freedom, Justice and Security, and then a few others, making the future of the progress in accession negotiations dependable on regulation of the issue of territorial waters in the Gulf of Piran. Status quo existing then meant that Slovenian ships were forced to cross either Croatian or Italian territorial waters if they wanted to reach open sea. Slovenia demanded a solution that would open an access to international waters. Conflict is well explained by an expert from the Polish Institute of International Affairs, who thinks that: "States remaining in a conflict appealed to different interpretations of the United Nations Convention on the Law of the Sea. Croatia emphasizes this part which requires the sea border to be drawn along so-called "baseline". Sea borders between Croatia and Bosnia and Herzegovina and Montenegro were drawn according to this rule. Slovenia indicates the historical arguments and this part of the Convention which refers to the countries of unfavourable geographic location."

Slovenian attitude led to blocking the process of negotiations in December 2008 and to postponing twice intergovernmental conference devoted to accession negotiations during the Czech presidency in the Council of EU, favourable to the idea of enlargement, in the first half of 2009. Croatian path to the Union was unblocked thanks to signing CroatianSlovenian agreement on November 4, 2009. This agreement assumed bringing the case to the court of arbitration ${ }^{5}$, which both countries did on May 25, $2011^{6}$.

${ }^{4}$ T. Żornaczuk, Chorwacko-stoweński spór graniczny a negocjacje akcesyjne Chorwacji z UE, „Biuletyn PISM”, No 28 (560), 22 V 2009.

${ }^{5}$ S. Hooper, Croatia, Slovenia sign border dispute deal, 4 XI 2009, http://edition.cnn.com/2009/WORLD/europe/11/04/croatia.slovenia. agreement/index.html.

${ }^{6}$ Slovene-Croatian Border Arbitration Deal Registered with UN, 26 V 2011, http://www.ukom.gov.si/en/media_room/newsletter_slovenia_ 
Cooperation between Croatia and the International Criminal Tribunal for the former Yugoslavia (ICTY) was a separate problem. Cooperation between individual Yugoslav republics and the Tribunal was supposed to be a kind of settlement with the period of war, that took place in former Yugoslavia in the first half of the 90s. This is why Croatia was obliged to hand over the accused of crimes committed during the war and to be of further assistance, for example by sending documents. Cooperation between Croatia and ICTY went quite well apart from the case of general Ante Gotovina, responsible for carrying out the operation "Storm" in 1995, which practically ended the war in Croatia and brought back the supremacy of Zagreb over almost whole territory of the country, but on the other hand it resulted in massive exodus of Croatian Serbs. Because of impossibility to capture/surrender general to a international justice the European Union suspended for unlimited time beginning of the accession negotiations with Croatia in March 2005. Special task group aiming at assessing cooperation between Croatia and ICTY was set up then.

After authorities in Zagreb accepted Action Plan aiming at finding Ante Gotovina, ICTY prosecutor Carla del Ponte assessed cooperation between Zagreb and Hague as "full" which enabled starting the accession negotiations the same day. Since capturing Gotovina in the Canary Islands in December 2005 cooperation with the Tribunal practically comes down to transfer of the documents. Both the Union and the Tribunal in Hague had some reservations concerning this issue, but it should not influence negatively accession of Croatia to the European Union.

It can be said that issue of cooperation with the International Criminal Tribunal and following escalation

news/news/article/393/2695/48f5c149c6/?tx_ttnews[newsletter] $=109$. On the Croatian-Slovenian conflict go to: M. Kaczorowski, Spór chorwacko-stoweński o Zatokę Pirańska, „Polski Przegląd Dyplomatyczny” 2009, No 4-5 (50-51), pp. 135-150. 
of the conflict with Slovenia delayed Croatian membership in the European Union for more or less 2 years.

During negotiations the biggest difficulties were encountered in the following chapters: 8 - Competition Policy, 11 - Agricultural \& Rural Development, 13 - Fisheries and 23 - Judiciary and Fundamental Rights.

When it comes to competition policy the main problem of the government was restructuring of the shipbuilding and steel industries, which were supported by substantial public help. Shipyards in Croatia provide a significant number of jobs (12 thousands of people employed in shipyards themselves and further 35 thousands in related businesses) and add up to $15 \%$ of Croatian export. For this reason Croatian government has been postponing the decision about privatization of this sector for a long time, as it would lead to loss of many jobs in the shipyards and possibly also their partial closing. Facing finalization of the negotiations and adamant EU's stand which demanded that the public assistance for shipyards would cease, a few unsuccessful attempts were made to privatize enterprises from this sector between the years 2009 and 2011. Current plans of restructuring were approved by the European Commission and by the Croatian Agency for Competition Protection, but until today the process of privatization has not entered the final phase yet. Accession Treaty contains two separate protocols concerning plans of restructuring of the shipbuilding and metallurgy industries and their monitoring by the Commission.

In the are of agriculture Croatia asked for record number (29) of exclusions and adjustments periods. The governmental stand on this issue was uncompromising because farmers are the traditional voters for ruling party HDZ, often hostile towards the EU. Similar problem appeared in the negotiations concerning fisheries.

Croatia also encountered serious problems when it comes to reforms within the areas from the chapter 23 . It 
covers issues connected with justice, fight against corruption, fundamental rights and rights of the EU citizens. The biggest challenge was to carry out complex reforms which will provide basis for independent, impartial, professional and effective system of justice. Priorities included creating new system of recruitment and promotion of judges, rationalization of the division of work and increasing efficiency of the courts which as a consequence would lead to shortening the time in which the cases are dealt with. Effective fight against corruption was also problematic. EU pointed out lack of political will to fight against the corruption at the highest level, lack of transparency in redistributing public money, lack of specialized units of police and prosecution fighting against these dealings, lack of legal solutions which would make the fight against corruption easier (such as law on confiscation of assets acquired illegally). When it comes to fundamental rights the issues of minorities and their protection, including return of the refugees and guaranteeing their rights turned out to be the biggest problem. Croatian governments made complex efforts for the sake of harmonization of the law with the European norms. In 2008 Strategy of Justice System Reform, Anticorruption Strategy, Action Plan for Implementation of the Constitutional Rights of Minorities were approved and started to be realized. Significant improvement in the efficiency of the courts and fight against corruption was achieved. Change of authorities and resignation of the long-term prime minister Ivo Sanader in 2009 made the efficient fight against corruption possible at the highest level, although there is concern that it might be just an isolated case. Concerning the comprehensive character of the reforms it is difficult to introduce changes in a short time. This is why it is necessary to wait for the real effects of the actions undertaken now. The EU also took it into account and decided to monitor implementation of the reforms within this area until Croatian full membership in 
the EU. It is worth emphasizing that reform of the justice system and fight against corruption would be much more difficult if it was not for the involvement of the civil society organizations, more specifically 15 of them dealing with areas of functioning of the state falling into 23 chapter of the accession negotiations.

The European Commission has also doubts concerning quality of public administration in Croatia. For the EU it is of the utmost importance because of possibilities of implementation and application of the Union's law and fulfilling the commitments of the member state. EU points out excessive employment, lack of competence, expanded and fragmented structure of croatian central and local administration.

Negotiations between Croatia and the European Union encountered two more obstacles. The first was the attitude of Croats towards the EU and the second - attitude of the member states towards further enlargement of the EU.

Social support for the Croatian membership in the European Union swung but generally decreasing tendency could be noticed. Between years 2006 and 2008, meaning at the moment of carrying out negotiations, the percentage of people positively assessing membership in the EU dropped from 35 to 29. Support for Croatian integration with the Union was bigger in the cities (35\%) and among the higher education graduates (51\%), while inhabitants of the rural areas presented far more eurosceptic attitude, supporting for the integration hardly exceeding $20 \%$. What is more in the Eastern Slavonia almost $60 \%$ of the inhabitants stated that they are badly informed or not informed at all about the process of the European integration ${ }^{7}$.

In the period between 2006 and 2009 percentage of people who believed that the European Commission wants

${ }^{7}$ Perceptions of the EU in the Western Balkans, Gallup Balkan Monitor 2009, pp. 6-7, http://www.balkan-monitor.eu/files/Gallup_ Balkan_Monitor-Focus_On_EU_Perceptions.pdf. 
to see Croatia in the EU also decreased from 55 to 43. Research carried out in 2009 indicated that Croats noticed serious threats resulting from the membership in the united Europe. For example 51\% thought that membership would negatively influence their sense of national identity. $46 \%$ were afraid of worsening their financial situation. For $44 \%$ of Croats integration with the Union meant weakening country's competitiveness and decrease in the welfare. Every 1 in 5 Croats perceived membership in the EU as a threat to democratic rules, and every 1 in 3 for their personal freedom. One forth of the citizens were also afraid of increase in taxes and decrease in the level of security ${ }^{8}$. Croatian authorities had to answer these questions and address the worries.

Research carried out in 2010 showed that over 50\% Croats feel well informed about the European Union. On the other hand the same polls indicated that only $25 \%$ Croats consider membership in the Union to be a good thing and $32 \%$ were of opposite opinion. Consequently $38 \%$ Croats thought that their country should join the Union and $42 \%$ opposed the idea. Over 35\% Croats thought in 2010 that it will be these who are already prosperous that will benefit from joining the Union while similar percentage of Croats were convinced that everyone (24\%) or nobody (23\%) will benefit from the accession ${ }^{9}$.

In spite of this relatively negative attitude of Croats towards the process of accession, research proves that Croats were conscious of awaiting challenges and necessity to carry out reform. Over $80 \%$ of the surveyed emphasized importance of introducing proper legislation, in line with the EU requirements. Over $2 / 3$ thought similarly when it comes to necessity of cooperation with the International Criminal

\section{${ }^{8}$ Ibidem.}

${ }^{9}$ Data available on the webpage of the Gallup Balkan Monitor: http://www.balkan-monitor.eu/index.php/dashboard. 
Tribunal in Hague. Almost $80 \%$ were aware of the need to resolve the conflicts with the neighbours ${ }^{10}$. According to results of the survey from July 2011, 60\% Croats would vote for the membership in the Union in the referendum, while $31 \%$ would oppose this idea ${ }^{11}$.

Carrying out accession negotiations with such a complex social attitude required adopting particular strategy of action and communication with the society. A perfect example is provided by the ruling in 2011 party HDZ concerning conviction of Ante Gotovina for crimes committed during the war in 1995. 95\% Croats considered this sentence to be wrong and support for Croatian membership in the Union decreased in April 2011 to only 23\%. Prime Minister Jadranka Kosor repeatedly criticized the decision of the tribunal in Hague, treading a fine line between support of voters in the country and support for the European aspirations of Croatia abroad.

Apart from the eurosceptic attitudes in the country, the Croatian authorities had to convince surprisingly many European partners of legitimacy and need for further enlargement of the European Union. Negative attitude of the majority of Western countries towards enlarging the Union by the Balkan countries is a result of many parallel processes. Above all economic and financial crisis that touched Europe is a problem indirectly linked to enlarging the Union by the "poor" countries from the Central Eastern Europe. This crisis led to the situation when member states of the EU are more prone to concentrate on the internal problems, less eager to help others.

What is more, an issue of massive migrations is widely discussed in Europe, especially Western Europe, vision of

${ }^{10}$ Ibidem.

${ }^{11}$ M. Ššstarić, From Zagreb with Love: On the Bounded Rationality of Euroskepticism and Europhilia in Croatia, http://www.balkanalysis. com/croatia/2011/09/12/from-zagreb-with-love-on-the-bounded-rationality-of-euroskepticism-and-europhilia-in-croatia/. 
the next 'Balkan wave' of immigrants discourages politicians who would like to make efforts aiming at conducting policy favourable to enlargement. Obviously these arguments do not find their reflection in the reality. Croatia is a small country, relatively well developed economically. Its accession will not have a big influence on the Union, will not cause excessive spending and it will not force the necessity to face sudden wave of immigrants either.

Enlargement process often falls victim to the internal policy of particular member states of the EU. Sometimes, as it happened with Slovenia, it was about using accession negotiations for gaining advantage in the conflict with Zagreb $^{12}$. A candidate state, such as Croatia, has often been a victim of internal political game, often oriented to showing the leaders of the member states as following strictly the Union's coherence and adapted rules of game. This way for example London, Hague, Stockholm or Berlin can show to their voters concern and struggle in the name of the local voters' interests, regardless of the fact that Croatia has not posed any threat to them.

It remains also a fact that for different reasons societies and often also governments of individual states pay less or more attention to particular problems. For example the United Kingdom, Finland and Belgium for a long time have blocked opening negotiations concerning system of justice using as the arguments negative reports on cooperation between Zagreb and international system of justice, fight against corruption and against the organized crime.

The way particular states behaved was complicated and not so clear, often a contradictory result of social attitudes, internal political game and real interests of the state. It should be added here that apart from the Slovenian exception, all the new member states of the European Union,

12 There was a similar situation concerning the conflict between Macedonia and Greece. 
including Bulgaria and Romania consequently supported the European aspirations of Croatia.

The negotiations were finalized on June 30, 2011. The last closed chapters included - Fisheries (chapter 13), Competition Policy (chapter 8), Judiciary and Fundamental Rights (chapter 23), Financial and Budgetary Provisions (chapter 33) and Other Issues (chapter 35). Draft of the Accession Treaty, drawing Croatia as a member state of the European Union was delivered to the Prime Minister Jadranka Kosor by the Polish Prime Minister Donald Tusk on September 17, 2011. Enlargement policy of the European Union became paradoxically a success of Polish presidency in the EU. Paradoxically because apart from consistent support for enlargement of the Union in the South East, Poland has not been actively involved in the process of support of the reforms in this part of Europe. Countries such as Hungary, Czech Republic, Slovakia, Slovenia, Romania, Bulgaria, Austria, Germany, France and Italy showed much more interest and/or put incomparably more effort into the process of enlargement than Poland did. Nonetheless it was the time of Polish presidency in the EU when the Accession Treaty was signed by Croatia and if everything goes well, Serbia will obtain a status of a candidate at the same time and Montenegro will start accession negotiations. Poland may become, again paradoxically, similarly to Russia in the $19^{\text {th }}$ century, a symbol of hope for better tomorrow for Balkans. How strong the position of Croatia will be in the united Europe does not depend only on the provisions of the treaty, but also on other factors.

The European Commission judged that "Croatia reached a high level of preparations for membership". The Commission underlined also need for "maintaining its efforts to align with the acquis and further strengthen its administrative capacity, including through sustainable progress of its public administration reform". It also warned also that "it will continue to monitor closely Croatia's ful- 
fillment of all the commitments undertaken in the accession negotiations, including those which must be achieved before the date of accession, and its continued preparations to assume the responsibilities of membership upon accession. Monitoring will focus in particular on commitments undertaken by Croatia in the area of the judiciary, the fight against corruption, and fundamental rights, in the area of justice, freedom and security, including border management, as well as in the area of competition policy. If issues of concern are identified during the monitoring process and are not remedied by Croatia, the Commission will, when necessary, address early warning letter to the Croatian authorities and may propose to the Council to take all appropriate measures already prior to accession. The Commission also reserves the right to invoke the various safeguard clauses set out in the Accession Treaty as well as the specific mechanism for State aid to the Croatian shipbuilding and steel industries" ${ }^{13}$. This is a very important message both for Croatia and for the member state of the European Union. Until the reforms are finished the European Commission will monitor work of the Croatian government and parliament. If the assessment is negative, the Commission will take appropriate measures. This is a real threat to Croatian accession to the EU. It has to be remembered that the Accession Treaty must be ratified by all the member states of the EU and from the unofficial talks with representatives of some of them it seems that some of the Western European countries may, even though does not have to, have serious problems with it. It means that if Croatian government stops the reforms, instruments of control and monitoring applied to Romania and Bulgaria will not be necessary - Croatia will not join the Union or will join it with a big delay.

${ }^{13}$ Commission Opinion on the application for accession... 



\section{Chapter III \\ Croatia in the European Union}

\section{Institutional aspects}

After accession to the European Union Croatia will acquire given number of votes in the Council and in the European Council, given number of seats in the European Parliament as well as right to send its representatives to other European institutions. Thanks to it Croatia will be able to represent its stand and interests as well as to influence the process of decisions making of the European Union.

Croatia will increase the number of small countries, whose number of inhabitants does not exceed 5.5 million, up to twelve. Next eight countries are inhabited by 5.5-12 million people. The Netherlands and Romania as the medium countries have respectively 16.5 and 21 million inhabitants. So-called "big six" include Poland (38 million), Spain (47 million), Italy (60 million), the United Kingdom (62 million), France (64 million) and Germany (81 million).

Croatia will have to face a few problems in translating state politics into the European level. First it will not have such a big influence as big member states have to effectively shape the EU politics. Second, taking into consideration relatively law GDP and law number of population, administrative or financial resources, necessary to build strategy or political plans, will be much weaker than those of the rich or bigger countries. Third thing is that Croatia will be a new 
EU member, therefore it will not have close institutionalized contacts with Union's institutions, above all with the European Commission. To a big extent it will not have practical knowledge on how to shape European politics in a "nonlegislative" way ${ }^{1}$. Poland needed a few years to effectively prepare, present and guarantee adopting a legislation proposal - Zagreb will surely need a few years as well.

Current process of decision making as well as institutional system mixes federal or community elements with the intergovernmental ones. The discussion that is taking place nowadays concerning future shape of the EU focuses on strengthening either community elements or the intergovernmental ones. Generally speaking, the community attitude should be as a rule preferred by small states. Vision of institutions such as strong European Parliament or the Commission, which are led by interests of whole the Union and not its most important, the richest (namely paying the biggest amount of money into the common budget) and the biggest members, is a convincing alternative to the intergovernmental method for small states, including obviously Croatia. The dominating intergovernmental method puts the majority of power in the hands of both Councils. Domination of the big states is especially visible in the Council of the European Union. On the other hand states, especially the small ones, will try to protect their interests, without shifting the responsibility towards international institutions - issues of legitimization and sovereignty will surely influence heavily the Croatian attitude to the institutional shape of the EU.

The political system of the EU in power until now, even though emphasizing the intergovernmental method, lets small states present and protect their stand, even in the op-

${ }^{1}$ More about functioning of small states in the European Union here: D. Panke, The Influence of Small States in the EU: Structural Disadvantages and Counterstrategies, DEI Working Paper 08-3, UCD Dublin European Institute, May 2008. 
position to the giants such as Germany or France. Generally each member state has three ways of influencing widely understood decision making process of the EU. These are:

- Voting weights, which reflect the socio-economic power of a given state

- Ideological way, prepared by experts and technical background

- Institutional way based on participation of representatives of a given country in particular Union's institutions, such as the European Commission ${ }^{2}$.

Efficient functioning of Croatia on the European Union's forum will depend mainly on its ideological and institutional abilities. These two factors can be relatively easily modified and strengthened. It seems possible for Croatia to prepare first, innovative proposal or to let its representatives get to know rules of game in particular Union's institutions in 2-3 years. It is impossible for Croatia to for example double the number of votes in the Council in the same time.

Croatia will have to depend on getting to know, understanding and proper using elements of the decision making process, which are not directly linked to the voting in the Council. Presenting relevant arguments, ability to build a coalition or making compromises can easily compensate for small number of votes in the Council. Given its size and analytical limited expert and administrative resources Croatia will have to determine its priorities and simply ignore the issues which are not very important. Zagreb's position will surely be strengthened by setting up strategic partnership, similar to those created by the Baltic states, Benelux or Spanish-Portuguese and German-French tandems. The most probable partnerships include alliances with Hungary, Austria or Italy, each of them potentially including also Slovenia.

Croatian veto will also be more efficient and it will be possible to use it more often if it is presented during the

\footnotetext{
${ }^{2}$ Ibidem, p. 5.
} 
initiation of the decision making process. It should be mentioned here that small states, including also Croatia, are in a way discriminated by the European Commission in the process of setting up agenda and legislation proposals. Interests and stands of the big countries are mainly taken into consideration and their opinion is of a key importance in the initial phase of decision making or planning.

\section{THE EUROPEAN COUNCIL}

Croatia, as a member of the European Union, will also participate on equal basis in the meetings of the European Council, which boosts the Union's development and shapes general directions and political priorities. The European Council also influences many other aspects of the Union's functioning, for example it appoints its President, the President of the European Commission, the High Representative of the Union for Foreign Affairs and Security Policy and the President of the European Central Bank. Decisions are made when consensus is reached, meaning all the participating states, including Croatia, have to agree. Croatia will be able to, even if to limited extent because of its geopolitical, demographic and economic position, influence these decisions. Because of constitutional system similar to the Polish one and the political divisions it is not yet sure who will represent Croatia in the European Council. Most probably it will the Prime Minister of Croatia but it cannot be ruled out that the President himself will be also willing to participate. A lot depends on the results of the elections and division of power between the Parliament and the Presidential Palace.

\section{THE COUNCIL OF THE EUROPEAN UNION}

Croatia will have relevant number of votes in the Council of the European Union, the most important legislative organ 
of the EU. The path of legislation is quite complex. Qualified majority in the Council requires that the decision is made by:

- $67 \%$ of the member states (but if the legislative proposal comes from the European Commission it requires only half of the state members). It means respectively 18 and 14 member states. After Croatia joins the Union only the first number will change up to 19 .

- $74 \%$ of votes, current 255 out of 345 will change into 260 out of 352 (345 of current votes plus 7 Croatian votes). Croatia, similarly to Denmark, Ireland, Lithuania, Slovakia and Finland will have 7 votes in the Council. More than Latvia or Slovenia by 3 votes and less than Austria, Bulgaria and Sweden by 3 votes. Therefore 7 Croatian votes themselves will not have such an importance.

- $62 \%$ of the population represented in the Council - now it means 311 million (out of 484.2 million). After Croatia's accession population will reach 488.65 million, out of which Croats will constitute $1.09 \%$. Also this factor will not mean for Croatia many opportunities to heavily influence decisions of the Council.

From 2014 qualified majority of votes will be simplified to $55 \%$ of the states and $65 \%$ of the votes. It means that from 2014, namely half a year after Croatia joins the European Union, the number of votes necessary to make a decision in the Council will decrease, meaning also the decrease in the influence of the small states. Big and medium states will need 15 states supporting given proposal.

What is more, new voting system requires support of the states representing $65 \%$ of the population, meaning more than currently. There are only 8 states with population exceeding 12 million of inhabitants. This will influence positively legislative power of Croatia.

Voting system that will be introduced in 2014 assumes also that legislative proposal can be rejected if at least four member states vote against it. Practically it means that even four small countries (such as Slovenia, Croatia, Malta and Cyprus) will be able to block the decision making process. 
When the Council makes decision based on the consensus Croatian vote will have obviously the same importance as the German or French one but using veto too often blunts its blade and makes the vetoing state not every credible.

It means that Croatia, belonging to a group of small states, wanting to influence the decision making process will have to use the ability to convince the European partners to its ideas. There are surely some constellations in which Croatia will tip the balance in the Council. Scope of the issues requiring unanimity leaves Croatia quite a powerful weapon in the key "non-economic" issues.

Current voting system in the EU means that Croatia will be able to use the veto in following areas:

- Union's enlargement

- Taxing

- Finances of the Union (including budgetary issues)

- Harmonization of the legislation in the areas of security and social assistance

- Some of the issues related to Justice and Internal Affairs (such as operation cooperation of the police, family law, European prosecutor)

- Common Foreign and Security Policy (with certain exceptions)

- Common Security and Defence Policy (with certain exceptions)

- European citizenship

- Some of the institutional issues (such as election system and composition of the European Parliament, some appointments, composition of the Committee of the Regions and the European Social and Economic Committee, revision of the treaties).

As additional „reinforcement” of the Croatia's position on the EU forum rotational Presidency in the Council, which lets the state, even the small one, lead the Council's proceedings for half a year, should be mentioned. It is 
highly doubtful that Croatia will handle the Presidency before the year 2020, because there are dates established for other member states until the end of this year.

\section{THE EUROPEAN PARLIAMENT}

Croatia will have 12 members of parliament in the European Parliament (out of 736 in general and from 2014, namely from the $7^{\text {th }}$ term of office -751 ), the same amount at Ireland and Lithuania and one less than Denmark, Slovakia and Finland, more than Latvia or Slovenia that have respectively 8 and 7 MPs in the European Parliament. Two biggest Croatian parties will strengthen two main European groups - HDZ will be a member of the European People's Party and SDP of the Progressive Alliance of Socialists and Democrats in the European Parliament. It is hard to predict if other, much smaller Croatian parties will get to the European Parliament - they might join the Alliance of Liberals and Democrats for Europe (HNS), the European Conservatives and Reformists, Europe of Freedom and Democracy (HSP) or the Confederal Group of the European United Left. Croats can count on at least one appointment for the deputy president of one of the parliamentary commissions.

Judging by Polish experiences after signing the accession treaty, the Croatian observers in the European Parliament will be invited to participate in the work of parliamentary commissions etc. After joining the Union in July 2013 until new elections which most probably will be held in summer 2014 Croatian observers, at least 12 out of them, will be granted the rights of MPs.

\section{THE EUROPEAN COMMISSION}

Croatia will have right to appoint one commissioner in the European Commission. It is hard to say now what area the Croats will take over. Probably in the first year of the 
membership in the EU they will be granted less important position, similarly to Bulgaria and Romania in 2007. Future composition of the Commission is impossible to predict.

CROATS IN OTHER INSTITUTIONS OF THE EUROPEAN UNION

The President of the Croatian National Bank will become a member of the General Council of the European Central Bank. Croat, probably the Minister of Finance, will become a member of the Board of Governors of the European Investment Bank. Croatia will be in one group with Poland ${ }^{3}$, which chooses 4 out of 18 deputy members of the Board of Governors.

Two consulting bodies, the Committee of the Regions and the European Economic and Social Committee will gain 9 members from Croatia each. Croats will be also in the European Court of Auditors (1 auditor), the Court of Justice of the European Union, Court (previously the Court of First Instance, currently an organ of the Court of Justice of the EU) and the European Union Civil Service Tribunal (1 judge in each). What is more, citizens of Croatia will be able to apply for jobs in the Union's institutions and agencies.

\section{Economic and financial aspects}

\section{BUDGET OF THE EUROPEAN UNION}

According to the European Commission's document from June 17, 2011 the amount of money that Croatia should have in 2013, namely in the last half of the year of the current budget, within so-called financial package, will amount

3 This group will also include Slovakia, Slovenia, Bulgaria, Czech Republic, Cyprus, Hungary and Malta. 
up to 473,4 million euro ${ }^{4}$. This sum was determined on the basis of accession experiences of the last twelve member states, taking into consideration current rules and profile of the payment in power since the beginning of the Financial Perspective for the years 2007-2013.

Table 1. The Financial Package for Croatia, proposed by the European Commission in the second half of the year 2013 (in millions of euro)

\begin{tabular}{|l|c|}
\hline 1. Sustainable growth & $\mathbf{2 4 2 , 3}$ \\
\hline $\begin{array}{l}\text { Competition of development and employ- } \\
\text { ment }\end{array}$ & $17,6\left(23,7^{a}\right)$ \\
\hline Coherence of development and employment & 224,7 \\
\hline $\begin{array}{l}\text { 2. Protection and management of the } \\
\text { natural resources }\end{array}$ & $\mathbf{1 4 , 3}$ \\
\hline Market-related expenditure & 9 \\
\hline Direct payments & 0 \\
\hline Reserve funds for mine clearance & 0 \\
\hline Development of the rural areas & 0 \\
\hline European Fisheries Fund & 4,4 \\
\hline Other support, Life + & 0,9 \\
\hline $\begin{array}{l}\text { 3. Citizenship, freedom, security and } \\
\text { justice }\end{array}$ & $\mathbf{4 2 , 2}$ \\
\hline Freedom, security and justice & 1,1 \\
\hline Adjustments to Schengen & $\begin{array}{c}40(80 \text { for the year } \\
\left.2014^{b}\right)\end{array}$ \\
\hline Citizenship & 1,1 \\
\hline Transitional Fund & $\begin{array}{c}0(29 \text { according to } \\
\text { the Councilc })\end{array}$ \\
\hline
\end{tabular}

${ }^{4}$ According to: European Union Common Position (revision of CONFHR 30/07). Charter 33 - Financial and budgetary positions, http:// www.mvep.hr/custompages/static/hrv/files/pregovori/ZSEUEN/33.pdf; European Commission, Non-paper on the DCP for Croatia on Chapter 33 Financial and Budgetary provisions. Inidcative forecast of payments appropriations and own resources payments. 
Table 1 (cont.)

\begin{tabular}{|l|l|}
\hline 4. EU as a global actor & $\mathbf{7 7 , 6}$ \\
\hline 5. Administration & $\mathbf{2 2}$ \\
\hline 6. Equalizations & $\mathbf{7 5}$ (in $\left.201428,6^{d}\right)$ \\
\hline Sum of the funds & 473,4 \\
\hline $\begin{array}{l}\text { Funds without point 5 (administra- } \\
\text { tion) }\end{array}$ & $\mathbf{4 5 1 , 4}$ \\
\hline Own funds & 267,7 \\
\hline Netto & 183,7 \\
\hline
\end{tabular}

${ }^{a}$ European Union Common Position (revision of CONF-HR 30/07). Charter 33 - Financial and budgetary positions, http://www.mvep.hr/ custompages/static/hrv/files/pregovori/ZSEUEN/33.pdf.

$b$ Treaty concerning the Accession of the Republic of Croatia, Council of the European Union, Brussels, 22 IX 2011 (OR. en), 14509/11, INF 162 ELARG 95, http://register.consilium.europa.eu/pdf/en/11/st14/ st14509-re01.en11.pdf, artykuł 31(2).

${ }^{c}$ Ibidem, article 30(4).

${ }^{d}$ Ibidem, article 32(2).

Source: Non-paper on the DCP for Croatia on Chapter 33 Financial and Budgetary provisions. Inidcative forecast of payments appropriations and own resources payments; own study.

According to article 27 of the accession treaty Croatia is obliged to pay to the European Investment Bank 42 millions 720 thousands of euro in 8 equal installments until November 2018. 494 thousands of euro from the Croatian budget will be devoted to the Research Fund for Coal and Steel ${ }^{5}$.

The European Union also established for the year 2013 Transitional Fund of 29 millions of euro. This position according to the European Commission's proposal is empty. Its aim is to develop and strengthen administrational and

\footnotetext{
${ }^{5}$ Ibidem, article 28.
} 
judicial abilities of the Republic of Croatia concerning implementing legislation and so-called "best practice" of the Union ${ }^{6}$.

Table 2. Predicted own funds of Croatia were calculated by the European Commission (in millions of euro)

\begin{tabular}{|l|c|}
\hline $\begin{array}{l}\text { Traditional own funds (levies on sugar, agriculture charge and } \\
\text { customs) }\end{array}$ & 25,5 \\
\hline $\begin{array}{l}\text { Own funds based on VAT (part of the national VAT tax col- } \\
\text { lected by the member states on the national level) }\end{array}$ & 36,5 \\
\hline $\begin{array}{l}\text { Own funds based on GNI (,national contributions” based on } \\
\text { GDI of individual member states) }\end{array}$ & 192 \\
\hline Lump sums & 1,5 \\
\hline Abatement of the United Kingdom & 12,4 \\
\hline Sum & $\mathbf{2 6 8}$ \\
\hline
\end{tabular}

Source: Non-paper on the DCP for Croatia on Chapter 33 Financial and Budgetary provisions. Inidcative forecast of payments appropriations and own resources payments; own study.

\section{THE COMMON AGRICULTURAL POLICY}

The Common Agricultural Policy (CAP) is one of the most important elements of the functioning of the united Europe. Obviously since the moment of Croatian's accession to the Union this state will participate in CAP. This policy concentrates both on subsidies for the agricultural production (or its limitation) and on development of the rural areas. Even though at the end of the 80s expenditure on CAP constituted almost $3 / 4$ of the EU's budget, this percentage has been gradually decreasing. Current financial perspective for the years $2007-2013$ grants $42 \%$ of the funds

${ }^{6}$ Ibidem, article 30 (4). 
in the budget to CAP, out of which more or less $3 / 4$ goes to direct subsidies and the rest to development of the rural areas.

In Croatia direct subsidies will be gradually introduced for 10 years according to established schedule aiming at reaching full level of payments, while in the first year of membership Croatian farmers will receive only $25 \%$ of what farmers from the "old" Union $\mathrm{do}^{7}$. Within funds for equalization of salaries and development of the rural areas, 10 millions of euro annually will be devoted to support the Croatian winery and in 10 years additional 9.6 millions of euro for mine clearance of the areas affected by war. Direct subsidies were not included in the table presented above as direct subsidies are deal with in the next year (usually in March).

Within IPARD in the year 2013 Croatia can use 27.7 millions of euro. Phasing in, namely gradual participation in the structures through enlarging sums that the state is eligible for within given policy, for the funds devoted to development of the rural areas within the Common Agricultural Policy was set up as follows: 30\% in 2013, 70\% in 2014, 90\% in 2015 and 100\% in 2016. Concerning development of the rural areas it was established that given a very short period of planning (6 months of the year 2013) it is not possible to effectively implement the national plan of development of the rural areas. Croatia should use in this period a pre-accession programme IPARD. As a kind of compensation the European Union suggested to Croatia benefiting from the whole amount of funds devoted to development of the rural ideas from 2014 instead of $80 \%$ planned earlier for this year.

${ }^{7} 1$ st year of membership (2013) - 25\%, 2nd year (2014) - 30\%, 3rd year $(2015)-35 \%, 4^{\text {th }}$ year $(2016)-40 \%, 5^{\text {th }}$ year $(2017)-50 \%, 6^{\text {th }}$ year $(2018)-60 \%, 7^{\text {th }}$ year $(2019)-70 \% \ldots, 10^{\text {th }}$ year of membership $(2022)$ $-100 \%$. 
Throughout negotiations Croatia guaranteed itself numerous exemptions and transitional periods. One of them postpones until 2018 adopting European standards within so-called good agricultural practice and ecological conditions for the agricultural production. Croatia can support production of white beet, some kinds of the olive oil, tobacco, breeding of cows and pigs with the funds outside of the common European policy for three years after accession. Zagreb will be able to use the reserve funds from the budget to help the most sensitive sectors such as breeding of the cattle, production of milk or tobacco.

From the moment of accession to the EU Croatia will have 12 months for registration of these agricultural and food products on the European level that have already been registered in Croatia as the local products, such as thick apple syrup - pekmez, various kinds of fruit brandy - socalled rakijas or prszut from Istria ${ }^{8}$.

Participation of Croatia in the Common Agricultural Policy after 2013 remains an unanswered question given the discussion about its future that is taking place right now. Currently the European Commission considers three alternative approaches to reforming CAP:

1. Continuation of the previous policy with correction of the most urgent imperfections, such as division of direct subsidies. Current system means significant differences between subsidies to acre in "old" and "new" Union with the biggest in 2010 difference between Greek farmer receiving 385 euro/ha and Latvian one receiving 21 euro/ ha. This alternative means additional benefits for these member states, whose level of agricultural development remains below the Union's average. It is not known though to what extent it will be in line with climate and energy policy of the EU.

${ }^{8}$ Interestingly, majority of these products are well-known and produced also in other states of the Balkan region. 
2. Changing the Common Agricultural Policy into more ecologically oriented policy, and at the same time more fair and efficient (oriented policy of subsidies together with making it more "green” and strengthened oriented development of the rural areas).

3 . The third option assumes practically total, but gradual giving up direct subsidies while reorienting policy towards more ecological one. This option is supported by the United Kingdom, the Netherlands, Sweden or Denmark, but objections both of the European Parliament and the Council makes it very improbable that it will be implemented, it will be an important bargaining chip though .

Keeping the existence and previous shape of the Common Agricultural Policy with equalization of the subsidies taking into consideration the interests of the new states, agriculturally weaker developed than the old Union, lies in the interests of Croatia, similarly in those of Poland as well. Consistently Croatia should also support proposal of the European Commission introducing limits of support (capping) for big farms, namely relatively bigger support for medium and small farms. The European Commission announces gradual introducing capping for the farms, whose revenue exceeded 150 thousands of euro, while sum over 300 thousands of euro will undergo complete reduction. Money from capping will be moved to the second pillar of CAP, devoted to development of the rural areas, not for direct subsidies. Money from capping will go back directly to the states, where they were generated, not to the Union's budget, from which they would be later redistributed. Small farms in Croatia will not benefit directly from capping. On the other hand this option is not unfavourable for Croatia as it is for the farmers in the Great Britain, Germany or Czech

${ }^{9}$ R. Gooch, European Commission publishes thoughts on CAP reform, 9 XII 2010, http://www.fwi.co.uk/Articles/09/12/2010/124683/ European-Commission-publishes-thoughts-on-CAP-reform.htm. 
Republic, where they have big farms. This is why it seems reasonable to support this option as moving in the good direction of strengthening the second pillar of CAP.

\section{COHESION POLICY}

Cohesion policy aims at equalizing level of the economic development and as a result also of level of life between different regions of the EU through increasing the economic, social and spatial coherence. "Economic coherence is measured with the help of the GDP per capita, taking into consideration purchasing power parity [...] Social cohesion is measured with the unemployment rate but more and more often participation rate is used for this purpose (a measure of the active proportion of an economy's labour force). [...] Territorial (spatial) cohesion is measured with the time of covering a given territory by air, road and railway transportation. Factor of the number of consumers available in a given time is also used"10.

As a rule the main benefactors of the cohesion policy include mainly new member states and some regions of the "old Union" such as part of Wales, Eastern Germany, Southern Italy or parts of Portugal, Spain and Greece. In 2012 the Union will devote over 44 billions of euro to the cohesion policy and in 2013 this sum will exceed 45 billions. In current shape cohesion policy will also include Croatia for half a year. Similarly as in the case of the Common Agricultural Policy, it is still unknown how the cohesion policy will change and in what direction it will evolve.

For the sake of cohesion policy Croatia was divided into three regions on the level NUTS $2^{11}$, corresponding

${ }^{10}$ Polityka spójności Unii Europejskiej (Cohesion Policy), Portal Funduszy Europejskich, http://www.funduszeeuropejskie.gov.pl/slownik/Strony/Polityka_spojnosci_Unii_Europejskiej.aspx.

${ }^{11}$ NUTS 0 are the member states, NUTS 1 (macro regions) have between 3 and 7 million people, NUTS 2 (in Poland territory of one 
with Polish voivodeships: Northern-Western Croatia Sjeverozapadna Hrvatska, Central and Eastern (Panonian) Croatia - Središnja i Istočna (Panonska) Hrvatska and Adriatic Croatia - Jadranska hrvatska.

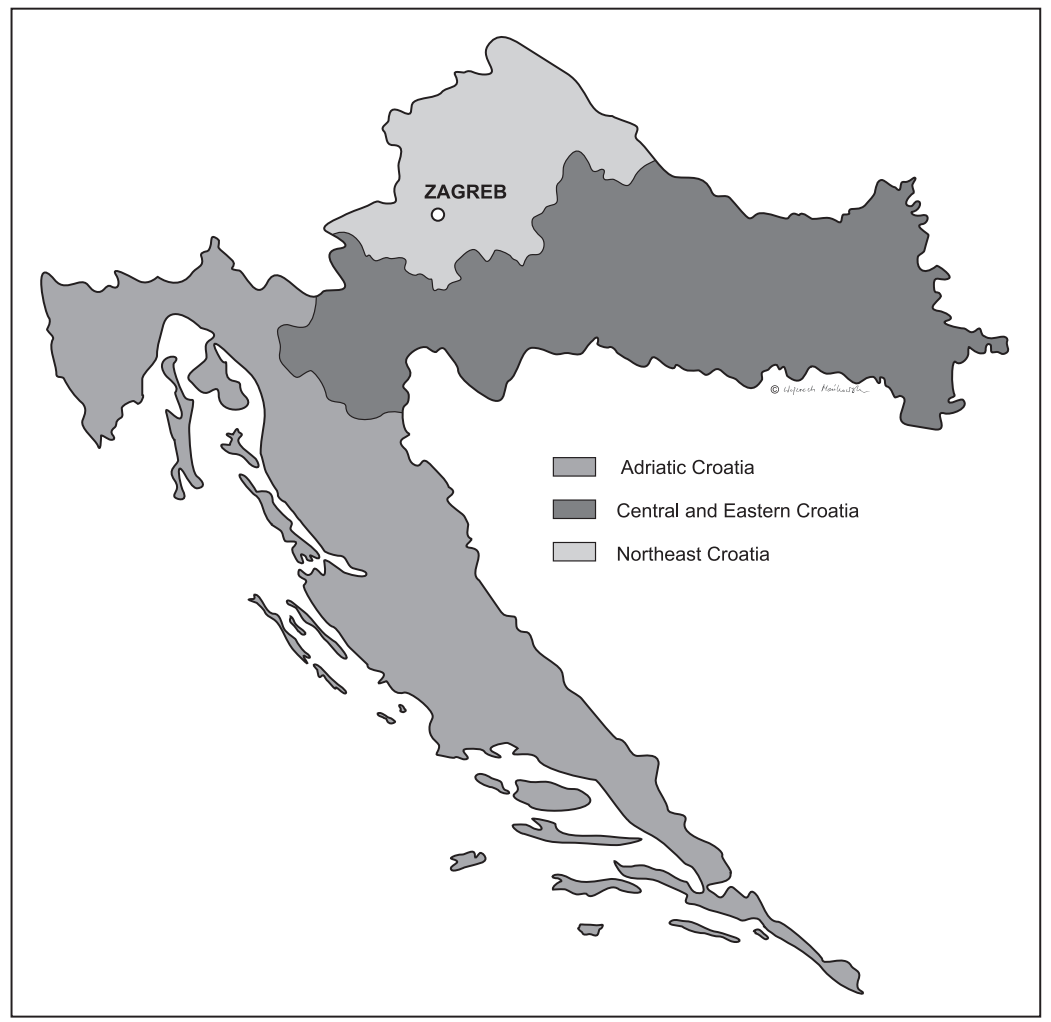

Prepared by Wojciech Mańkowski

Financing within „Policy coherence for development and employment", namely financially the biggest part of the coherence policy will undergo, similarly to the Common

voivodeship) are the regions inhabited by between 800 thousands and 3 million, and NUTS 3 between 150 and 800 thousands (sub-regions in Poland consisting of a few districts). 
Agricultural Policy, a process of phrasing in. So in 2013 Croatia will receive $30 \%$ of the sum that it would receive as an "old" member state. In 2014 this percentage will increase to $70 \%$, in 2015 to $90 \%$ and in 2016 to $100 \%$. This means that the sum of 449.4 millions of euro for the year 2013 (divided by half because Croatia will participate as a member state in the cohesion policy only from the second half of 2013) will be multiplied by 2.33 in the year 2014 (1.047 billion of euro) and by 3 in 2015 (1.348 billion of euro).

\section{ENERGY POLICY}

Issues of energy for many years have not been a subject of interest for the European Communities. Majority of the states thought that energy has a strategic importance for the national interests and refused to move the competences in this area to the common level. Breakthrough happened in the 80 s when the discussion on the energy sector was initiated on the European forum. In 1988 the European Commission published draft document in which a creation of common energy market was suggested. In following years many documents were published and numerous directives were adopted that created base for the common, liberal energy market.

Currently increasing dependence on import of the resources, increasing prices of energy and climate changes are the biggest challenges that the countries of the EU face. EU, in order to guarantee competitiveness, stability and security of supply, suggests creating internal energy market, increasing the efficiency of using it and growth of importance of renewable energy.

Dependency ratio of Croatia on the import of energy is $45.9 \%$ which is below Union's average - in 2009 it was $53.9 \%{ }^{12}$. This ratio is low mainly because of using own

${ }^{12}$ Countries Factsheets. Energy Statistics for EU-27, http://ec.europa. eu/energy/publications/statistics/doc/2011-2009-country-factsheets.pdf. 
natural resources to partially cover need for the gas and oil. Croatia imports electrical energy, gas, oil and also coal. In the national consumption oil (50\%) and gas (28\%) play the biggest role, renewable sources and solid fuels are of less importance (7\%). In October 2009 the Strategy for Development of the Energy until 2020 was adopted, it assumes harmonization of the national policy's aims with the Union's rules.

Croatia has well developed energy infrastructure, well integrated with the neighbouring states. It also fulfills the Union's requirements concerning obligatory stock of liquid fuels, which cover 90 days of average daily use.

Annual needs for gas reaches around 3.1 billion of $\mathrm{m}^{3}$, $64 \%$ out of which is covered by the own production. With regard to increasing need for gas and depletion of the resources dependence on import of gas will probably increase in the following years. At the same time Croatian authorities try to diversify paths of supply of this material. Until 2008 Croatia could only receive supply of gas through the connection with Slovenia, enabling transfer of 1.8 billion of $\mathrm{m}^{3}$ annually. In 2011 two-way gas interconnector with Hungary was open, enabling transfer of 6.5 billion of $\mathrm{m}^{3}$ annually. In the future it is supposed to enable transfer of gas from the terminal LNG on the island Krk, which will give the states of the Central Europe chance to receive gas other than the Russian one. Both these projects are in line with the Union's strategy of building the corridor North-South. Gas pipelines networks in Dalmatia are also developed, they are supposed to be extended to Montenegro and further to Albania which would enable transfer of gas from the planned pipeline TAP (Greece - Albania - Italy) ${ }^{13}$. Pipeline TAP is one of the projects within the Union's concept of the Southern Corridor (together with Nabucco and

${ }^{13}$ Trans Adriatic Pipeline, TAP. 
ITGI $^{14}$ ) of gas transfer, which would enable transfer of gas from Azerbaijan through Turkey with omitting Russia. If these projects are realized Croatia has a chance of playing an important role in gas transfer to the states of Central and Southern Europe.

\section{CLIMATE POLICY}

EU pays more and more attention to issues connected with the climate policy. In 2007 the European Council unanimously set the aims of reducing emission of the greenhouse gases until 2020 by $20 \%$, increasing share of renewable sources of energy up to $20 \%$ and increasing energy efficiency by $20 \%$.

Croatia adopted Plan for the improvement of the Energy Efficiency in $2010^{15}$. Majority of the regulations enabling increasing energy efficiency were adopted. The government promised to reduce need for the energy by $9 \%$ until 2016. National aim was set up in line with the Union's rules based on 5 years of average demand. Croatia is also obliged to reduce the emission of $\mathrm{CO}_{2}$ by around 800 thousands of tons annually.

Around 7\% of energy used in Croatia comes from the renewable sources, which is quite a high percentage in comparison to other states of the EU. However, majority of this energy is produced in big hydroelectric plants, which are not counted as so-called new renewable sources of energy. Acquisition of energy from small hydroelectric plants or solar power plants or wind power plants are of marginal importance for the energy production. Croatia adopted in 2010 New Plan for the Energy from the renewable sources and introduced guaranteed tariffs for the energy from these sources. In spite of adopted regulations which defined

\footnotetext{
${ }^{14}$ Interconnector Turkey-Greece-Italy, ITGI.

${ }^{15}$ National Energy Efficiency Action Plan, NEEAP.
} 
development of this sector and creating good conditions for acquiring energy from the renewable sources as strategic, Croatia did not manage to reach in 2010 defined target and acquire $5.8 \%$ of electric energy from the renewable sources. In current situation is seems to be highly improbable that Croatia would reach in 2020 the targets set by the EU.

EU supports also using biofuels and fuels containing biocomponents. Croatia declared that until 2010 it will increase the share of biofuels by $5.75 \%$.

\section{Cooperation in the area of the foreign policy}

Accession of Croatia to the European Union will have bi-vectorial consequences in widely understood area of the foreign policy. One vector will refer to the position of Croatia in the international context, the second one - to the directions of its interests.

Above all the position of Croatia will be strengthened both in Europe and indirectly in the world. Membership in the European Union moves the states to one of the highest levels in Europe. On the European Union's forum Croatia will be able to present and defend its stand surrounded by empires such as Germany, France or Great Britain. In many cases and basically in all the most important ones, vital issues Croatia will have a right to veto. In history of this state it is a breakthrough moment, which has never had a precedence. Regular meetings of the representatives of the Croatian authorities responsible for practically every element of functioning of the state, society and economy strengthens as a rule bonds between participating states and leaders.

On the other hand the European Union will not limit Croatia in its activities, as it has happened until recently in case of Germany. States which want or would like to play the role of the leader and engine of the European integration are often forced to see the foreign policy from much 
wider perspective, not only through their own interests. (Potential) regional leaders behave similarly, in order to achieve or maintain their position they should take into account interests of various partners. Position and geopolitical location of Croatia rules out possibility of playing such a role for a couple of years.

Accession of Croatia to the European Union will put in more favourable position in comparison to Serbia, Bosnia and Herzegovina as well as other states of the region Macedonia, Kosovo and Albania. In this context, comparing it to the Slovenian experience, Croatia will gain a powerful ally in the regional conflicts. Unfortunately membership in the European Union means leaving the Central European Free Trade Agreement. Poland, Hungary, Czech Republic and Slovakia had to do it in 2004, Bulgaria and Romania in 2007. Belonging to one free trade area practically rules out possibility of participation in another area of this kind. Croatia will be obliged to sign a number of agreements and international conventions ${ }^{16}$.

Due to its size and demographic as well as economic potential Croatia will not be able to extend its foreign policy by many new directions. Economic and financial bonds linking this country with German, Austrian and Italian partners and to smaller extent also with Hungarian, Slovenian and Bosnian ones indicate what factors will influence the foreign policy of Zagreb. What is more, participation of Croatia in two important ventures of the EU, namely Union for the Mediterranean and EU Strategy for the Danube Region directs attention of this state to Southern East. Both these policies, from the point of view of Polish interests, divert attention of the EU from the Eastern issues, being of key importance to Warsaw.

${ }^{16}$ Exhaustive list of 13 pages was added as Appendix I and II of the Accession Treaty. 
Polish authorities can count on that Croatia will become another state more in favour of further enlargements of the European Union, which will understand more than Ireland, Portugal, Denmark or Holland the relations between Russia, Belarus, Ukraine, Moldova and the EU.

\section{Challenges for Croatia}

Finalizing negotiations is a huge success of the Croatian government and is a crowning achievement of the economic and social transformation. At the same time it does not put an end to challenges that Croatian government has to face.

Finalizing the negotiations process with Croatia the EU took a step without precedence and decided to continue monitoring process of the progress in reforms by publishing annual reports. In the most problematic area for Croatia, namely justice and fundamental rights reports will be published even every half a year. It means that the Croatian government will be forced to continue implementation of the reforms. Stopping it may cause the problems with the ratification of the Accession Treaty. Even more so because the Mechanism of Cooperation and Verification, within which the progress in reforms of he justice system and fight against corruption in Romania and Bulgaria were monitored, has not been used in case of Croatia. It means that after ratification of the Accession Treaty member states will lose possibility of controlling how Zagreb adjusts to the Union's rules. Because of this member states may prolong the process of ratification and make it dependant on the subsequent reports.

Another challenge for the government is improvement of the economic situation of Croatia. Rapid growth was until now a result of big infrastructural investments of 
the government as well as national demand financed by the credits easily granted by the banks. Global economic crisis affected fragile fundaments of the growth and made the stagnation in Croatia longer than in other countries of the region. It led to one of the highest unemployment rate in the EU (only in Spain there are more unemployed). High tax and para-tariff burden as well as unfavourable climate for the business activity due to extended bureaucracy are also problems. These factors hinder the investments. Society and political elites count that membership in the EU will be an incentive for rapid economic growth thanks to improving credibility in the international context, unlimited access to the European market and structural funds. It will undoubtedly positively influence the situation but further reforms are necessary to build base for stable growth in the future. Fundamental changes are necessary in administration, health care, social assistance and system of pensions.

Becoming a member of the euro zone and Schengen will be the next step in the integration of Croatia with the EU. According to current Minister of Finance Martina Dalić, taking into consideration high degree of "euronization" of the Croatian economy adopting common currency will be a natural process and the government will aim at fulfilling the Maastricht conditions already in $2013^{17}$. In case of Croatian economy, not big and highly dependant on euro (around $80 \%$ of the deposits are denominated in this currency) minimizing exchange rate risk is a serious burden for the economy. This is why quick adaptation of the euro seems to be beneficial for Croatia. In this case though state gives up the possibility to improve

${ }^{17}$ K. Andrusz, Euro Adoption Would Be 'Natural' for Croatia, Finance Chief Says, 9 IX 2011, http://www.bloomberg.com/news/201109-09/euro-adoption-would-be-natural-for-croatia-finance-chief-says. html. 
its competitiveness through depreciation of the currency. Because of this the oppositional Party of the Social Democrats, which will most probably win the elections in December 2011, is far more skeptical towards the euro. Analysts also think that because of the scale of the economic crisis swift fulfilling the convergence criterion and joining the monetary union will be impossible. According to survey carried out by the Croatian Association of Researchers majority of experts think that it may happen no sooner that in the years 2018-2023.

When it comes to joining Schengen the government declares that Croatia will fulfill all the conditions for accession within two years since accession to the EU, namely in 2015. Controlling external borders will be the main challenge for Zagreb, which is not easier taking into consideration both the length of the borders $(1377 \mathrm{~km}$ with the countries outside of the EU) and shape of the country (numerous islands and enclave in the neighbourhood of Dubrovnik). During last couple of years Croatia has been improving the control over the borders within the Action Plan for Integrated Management of the Borders and it has been harmonizing legislation with Schengen acquis. Reforms in this area will be financed, among others, from the Fund for Schengen, within which 120 millions of euro are intended for Croatia (40 millions of euro in 2013 and 80 millions in 2014). Decision on Croatia accessing Schengen Area will require agreement of all the members and taking into account current problems of Romania and Bulgaria it cannot be ruled out that the date of Croatian accession will be delayed. It would be also easier if all the Balkan states joined the Schengen Area, which would make the control of the borders much easier and would reduce its costs. Taking into consideration current pace of these countries' integration with the EU there are very small chances of them acquiring the membership before 2020. It may delay integration of Croatia with the Schengen Area. 
Changes that are currently taking place in the EU itself also pose a challenge for Croatia. In 2013 Zagreb will become a member of a community that will look completely different than the EU, with which the negotiations started in 2005. It is not known yet how the monetary union will look like, the Schengen Area, agricultural policy and cohesion policy will be reformed. 



\section{Chapter IV \\ Conclusions for Poland}

As the Commission correctly pointed out: „The enlargement of the European Union, through the accession of Croatia, will contribute to strengthening stability, freedom and prosperity in Europe. Croatia is expected to continue to play an active role in regional cooperation in the Western Balkans. The Commission welcomes Croatia's declaration on promoting European values in South-East Europe and in particular Croatia's commitment that bilateral issues should not obstruct the accession process of candidate countries. Croatia's accession confirms the EU's commitment to the European perspective of all the Western Balkans countries"1.

Due to weak political, economic or social bonds between Poland and Croatia, accession of the latter to the Union will influence our country only to an extent to which it will influence shape of whole united Europe. Membership of Croatia in the European Union will have a direct influence mainly on the neighbouring countries and those involved in the region the most, such as Austria, Hungary, Slovenia, Italy or Germany. Poland will feel the consequences of the „second Balkan enlargement” only indirectly.

${ }^{1}$ Commission Opinion on the application for accession to the European Union by the Republic of Croatia, European Commission, Brussels 12 X 2011, COM(2011) 667, http://ec.europa.eu/enlargement/ pdf/key_documents/2011/package/hr_opinion_2011_pl.pdf. 
Membership of Croatia in the Union will insignificantly influence position of Poland in the decision making process of the EU. Small number of inhabitants and relatively small economic potential mean that balance of power in the Union's institutions will not undergo any major changes. For sure Croatia will need a certain time to work out its European policy and learn how to reach compromise and common solutions on the arena of the European politics.

Internal structure of the European Union will undergo changes though. The group of Southern European countries concentrated around the Union for the Mediterranean, now consisting of France, Portugal, Spain, Malta, Greece, Cyprus, Slovenia and Italy, will be surely strengthened. Croatia already supported the newly created Strategy for the Danube Region, soon it will strengthen this group on the Union's forum. Strategy for the Danube Region will draw more attention to the Southern Eastern Europe - this direction is more in line with the interests of Poland than the Southern vector connected with the Northern Africa.

Increasing the number of small member states of the EU may positively influence the role played by big states, such as Poland. What is more currently functioning formula V4 +, namely four countries of the Visegrad Group plus cooperating countries (for example Romania) will also be extended including subsequent countries of the Central Eastern Europe. It will be positively reflected in the Polish policy in the European Union. There is also hope that Croatia will not be indifferent to for example Eastern Partnership, namely Eastern direction of the European foreign policy.

Areas of integration such as Common Agricultural Policy or cohesion policy will gain a new beneficiary on the level of development similar to Polish one, meaning requiring significant financial support for a long time. Obviously it will also depend on the pace and directions of changes that will affect both of these policies after the 
year 2013. Accession to the European Union and then support received within Common Agricultural Policy will undoubtedly contribute to strengthening and development of Croatian agriculture. Polish policy in these areas may but does not have to gain an ally. A lot will depend on ability to convince Croatian partners to Polish stand in these areas.

Concerning the energy policy Croatia has already become of the key transit countries for the energy from the South East and to a less extent from Russia. It contributes to further diversification of the energy supply, but it will affect Poland only indirectly because of the lack of significant links between energy networks.

One can hazard a statement that enlargement of the Union by Croatia's accession will make the process of the internal integration slower. The weaker prepared Croatia will be for efficient functioning in the Union, the more probable this hypothesis is. Therefore Poland should support the best possible preparation of Croatia for the membership in the EU so that there are no arguments that could be used by the member states hostile towards further integration and enlargement of the Union.

Joining the European Union by Croatia should not, taking into consideration economic potential and demographic situation of this state, lead to flow of Croatian citizens to Poland. It should be also underlined that Croatia is traditionally linked with the countries of Western and Southern Europe, such as Austria, Germany or Italy and these countries are a possible target for the migration of the Croats. 



\section{Bibliographical indications}

Bibliography devoted to contemporary situation in Croatia is on Polish market very limited. Book by Krzysztof Krysieniela System polityczny Republiki Chorwacji [Political system of the Republic of Croatia] (Poznan-Chorzów 2007) and by Małgorzata Łakota-Micker Proces akcesji Republiki Chorwacji do Unii Europejskiej [Process of accession of the Republic of Croatia to the European Union] (Wrocław 2011) belongs to rarities. Other important positions concerning history and dissolution of Yugoslavia or contemporary situation of Western Balkans include: Jugostawia. Byt wspólny i rozpad [Yugoslavia. Common existence and dissolution] (Warszawa 2000) and Jugostawia. Państwa sukcesyjne [Yugoslavia. Successive states] by Wiesław Walkiewicz (Warszawa 2009); Komunizm. Federacja. Nacjonalizmy. System władzy $w$ Jugostawii 1943-1991. Powstanie, przeksztatcenia, rozktad [Communism. Federation. Nationalisms. System of power in Yugoslavia 1943-1991. Rising, transformations, dissolution] (Warszawa 2004) by Michał Jerzy Zacharias; Jugostawia. Historia w zarysie [Yugoslavia. Sketch of history] (Kraków 2011) by Leslie Benson; Batkany w XX wieku [Balkans in the 20 $0^{\text {th }}$ century] (Warszawa 2003) by Mieczysław Tanty; Vademecum batkanisty. Lata 500-2007 [Balkanist's vademecum. Years 500-2007] (Poznań 2009) ed. by Ilona Czamańska and Zdzisław Pentek; Integracja i dezintegracja Jugostawii na przełomie XX $i$ XXI wieku [Integration and desintegration of Yugoslavia at the turn of the 20th and 
21st century] (Poznań 2002) by Sebastian Wojciechowski; Batkańska pożoga. Wojny i konflikty na Batkanach w latach 1981-1999 [Balkan conflagration. War and conflicts in Balkans in years 1981-1999] (Warszawa 1999) by Maciej Kuczyński; Rozbicie Jugostawii. Od separacji Stowenii do wojny kosowskiej [Dissolution of Yugoslavia from seperation of Slovenia until war in Kosovo] (Warszawa 2003) and Rozbicie Jugosławii. Jugostowiańskie lustro międzynarodowej polityki [Dissolution of Yugoslavia. Yugoslav mirror of international politics] (Warszawa 2005) by Marek Waldenberg; Serbia pod rzadami Slobodana Miloševicia. Serbska polityka wobec rozpadu Jugostawii $w$ latach dziewięćdziesiatych XX wieku [Serbia under the rule of Slobodan Milošević] (Kraków 2008) and Ksztattowanie relacji między państwami bytej Jugostawii $w$ ostatnim dziesięcioleciu - zarys problemu [Shaping relations between former Yugoslav states in the last decade - outline of the problem] (Lublin 2010) by Mirella Korzeniewska-Wiszniewska; Proces instytucjonalizacji przemian ustrojowych w państwach postjugostowiańskich [Process of institutionalization of the transformation in the post-Yugoslav states] (Pułtusk 2007) and Przeobrażenia ustrojowe panstw postjugostowiańskich (1990-2003) [Transformation in the post-Yugoslav states (1990-2003)] (Pułtusk 2003) by Jacek Wojnicki; Państwa pojugostowiańskie. Szkice politologiczne [Post-Yugoslav states. Politological sketches] (Kraków 2008) by Ewa Bujwid-Kurek; Partie i systemy partyjne państw byłej Jugostawii (Bośnia i Hercegowina, Chorwacja, Czarnogóra, Macedonia, Serbia, Stowenia) [Parties and party systems in former Yugoslav states (Bosnia and Herzegovina, Croatia, Montenegro, Macedonia, Serbia, Slovenia)] (Pułtusk-Warszawa 2009) by already mentioned Krzysztof Krysieniel and Jacek Wojnicki; Batkany Zachodnie a integracja europejska. Perspektywy $i$ implikacje [Western Balkans and European integration. Perspectives and implications] (Warszawa 2008), ed. Rafał 
Sadowski and Jan Muś; Bośnia i Hercegowina 15 lat po Dayton. Przeszłość - teraźniejszość - perspektywy. Studia $i$ szkice [Bosnia and Herzegovina 15 years after Dayton. Past-presence - perspectives. Studies and sketches] (Łódź 2011), ed. by Paweł Chmielewski and Sławomir Lucjan Szczesio, as well as published since 1991 by Institute of Political Studies of PAN (Polish Academy of Sciences) Annual „Europa Środkowo-Wschodnia” [Central Eastern Europe], containing information about former Yugoslavia.

Numerous analysis, commentaries and articles are provided by analytical centres dealing with Balkans. Those include: Ośrodek Studiów Wschodnich - Centre for Eastern Studies (http://www.osw.waw.pl/), Polski Instytut Spraw Międzynarodowych - The Polish Institute for International Affairs (http://www.pism.pl) or Centrum Analiz Społeczno-Ekonomicznych - Center for Social and Economic Research (http://case.com.pl). Available, digitalized materials contain both short summaries of the most important events in the region of Balkans, including Croatia, and deep analytical drafts. Relatively many articles on Croatia can be found on the webpage of Portal Spraw Zagranicznych - Portal of Foreign Affairs (http://www.psz.pl) or in English on http:// www.euractiv.com/.

Documents and official data concerning the accession process of Croatia, also in English, can be found on the webpage of the Ministry of Foreign Affairs and European Integration of the Republic of Croatia (http://www.mvep.hr) and on the webpage of the European Commission (http:// ec.europa.eu/enlargement/index_pl.htm). 



\section{Appendix}

\section{Appendix 1 \\ Chronology of integration of Croatia with the European Union}

\section{May 1999}

The European Commission proposed setting up the Stabilization and Association Process (SAP) for Albania, Bosnia and Herzegovina, Croatia and Federal Republic of Yugoslavia.

\section{June 1999}

The Stability Pact was agreed on - a political document whose strategic aim was stabilization of South Eastern Europe through integration of this region with Euro-Atlantic structures and through strengthening the multilateral cooperation.

\section{February 2000}

EU - Croatia Joint Consultative Committee was set up.

\section{May 2000}

The European Commission presented programme CARDS (Community Assistance for Reconstruction, Development and Stabilization) - instrument of financial and technical 
assistance for South Eastern Europe in the years 20002006.

\section{May 2000}

The European Commission assessed Croatia positively before starting the negotiations of the Stabilization and Accession Agreement (SAA) between Croatia and the EU.

\section{June 2000}

The Council of Minister approved report of the European Commission concerning SAA, proving that Croatia fulfilled all the conditions necessary for starting the negotiations.

\section{June 2000}

Croatia became a member of the programme EUREKA.

\section{November 2000}

Members of the team negotiating conclusions of the SAA were appointed.

\section{November 2000}

Summit in Zagreb - beginning of the negotiations concerning SAA between Croatia and the Union.

\section{November 2000}

Government of the Republic of Croatia adopted guidelines for the negotiations of the conclusions of the SAA.

\section{December 2000}

The Council adopted an assistance programme CARDS.

\section{December 2000}

The first round of the negotiations concerning the SAA ended. 


\section{February 2001}

Commission of European Integration was formed within the Croatian Parliament.

\section{February 2001}

The beginning of the second round of the SAA negotiations.

\section{October 2001}

The Stabilization and Association Agreement and the Transitional Agreement are signed between Croatia and the European Union in Luxembourg.

\section{December 2001}

Croatian Parliament ratified the SAA.

\section{December 2001}

The European Parliament ratified the SAA.

\section{January 2002}

The Council of Ministers of the EU approved the Transitional Agreement.

\section{February 2002}

Austria ratified the SAA.

\section{March 2002}

The Transitional Agreement came into power.

\section{April 2002}

The European Commission published first annual SAP report about Croatia.

\section{April 2002}

Ireland ratified the SAA. 


\section{April 2002}

Denmark ratified the SAA.

\section{June 2002}

Croatian Parliament approved the Framework Agreement on general rules of Croatia's participation in the community's programmes.

\section{July 2002}

Germany ratified the SAA. The European Commission and the government of the Republic of Croatia signed the Agreement on Priorities of the Multiannual Indicative Programme (CARDS) for the years 2002-2004.

\section{September 2002}

Spain ratified the SAA.

\section{December 2002}

Croatian Parliament adopted a resolution on Croatia's Accession to the European Union.

\section{February 2003}

Sweden ratified the SAA.

\section{February 2003}

Croatia submits application for membership in the European Union.

\section{March 2003}

France ratified the SAA.

\section{April 2003}

The EU Council asked the European Commission to prepare an opinion concerning Croatian application for membership in the EU. 


\section{June 2003}

Luxemburg ratified the SAA.

\section{June 2003}

Greece ratified the SAA.

\section{July 2003}

Portugal ratified the SAA.

\section{July 2003}

The European Commission hands in to the Croatian authorities a questionnaire containing 4560 questions related to the Croatia's application for membership.

\section{October 2003}

Croatian authorities submit the fulfilled questionnaire to the European Commission.

\section{December 2003}

Belgium ratified the SAA.

\section{December 2003}

Finland ratified the SAA.

\section{February 2004}

Croatia ended the first round of negotiations with the European Union concerning Protocol 7 (trade) of the SAA.

\section{March 2004}

The European Parliament suspended activities of the Delegation for South Eastern Europe, a special Committee for contacts with Croatia was set up. 


\section{March 2004}

Republic of Croatia became a full member of the programme CADSES.

\section{April 2004}

The European Commission issued a positive opinion (avis) concerning Croatia's application for the membership in the EU.

\section{April 2004}

The Netherlands ratified the SAA.

\section{June 2004}

Croatia was granted a status of the candidate state.

\section{September 2004}

The Council adopted the European Partnership for Croatia.

\section{October 2004}

The European Commission published the Pre-Accession Strategy for Croatia.

\section{December 2004}

The European Council set a date for starting the accession negotiations, however emphasizing necessity of Croatia cooperating with the International Criminal Tribunal for the former Yugoslavia.

\section{May 2005}

Croatian Parliament adopted following documents connected with the European integration:

- Statement concerning Common Actions of the Government and the Parliament;

- Declaration on Fundamental Rules of Negotiations; 
- Decision on Setting up the National Committee for Monitoring the Negotiations.

\section{February 2005}

The SAA comes into power.

\section{March 2005}

The Council adopted the Negotiations Framework for Croatia but did not manager to reach a consensus concerning opening of the accession negotiations - negotiations are not launched.

\section{April 5}

The first meeting of the Croatian-Union's Council of Stabilization and Association.

\section{October 2005}

Carla del Ponte's positive report concerning cooperation between Zagreb and Hague. The accession negotiations are started between Croatia and the EU.

\section{October 2005}

Beginning of screening of the Croatian legislation in terms of its compatibility with the acquis communautaire.

\section{October 2005}

The first intergovernmental conference, during which the rules and procedures for the accession negotiations are set up and preliminary schedule is discussed based on the programme of screening of the legislation in particular negotiation chapters.

\section{December 2005}

General Ante Gotovina was captured on the Canary Islands and was handed over to international justice. 


\section{February 2006}

The Council of the European Union adopted Accession Partnership for Croatia.

\section{April 2006}

The second meeting of the Council of Stabilization and Association.

\section{June 2006}

Chapter 25 - Science and Research is opened and temporarily closed.

\section{October 2006}

The screening process was ended.

\section{December 2006}

Charter 26 - Education and Culture is opened and temporarily closed.

\section{December 2006}

Chapters: 17 - Economic and Monetary Policy, 20 - Enterprise and Industrial Policy and 29 - Customs Union were opened.

\section{March 2007}

The third meeting of the Council of Stabilization and Association took place.

\section{March 2007}

Chapter 7 - Intellectual Property Law - was opened.

\section{June 2007}

Chapters: 3 - Right of Establishment and Freedom to Provide Services, 6 - Company Law, 9 - Financial Services, 
10 - Information Society and Media, 18 - Statistics and 32

- Financial Control were opened.

\section{October 2007}

Chapters 28 - Consumer and Health Protection and $30-$ External Relations were opened.

\section{December 2007}

Chapters 21 - Trans-European Networks and 33 - Financial and Budgetary Provisions were opened.

\section{February 2008}

The Council of the EU adopted revised Accession Partnership for Croatia.

\section{April 2008}

Chapters 14 - Transport Policy and 15 - Energy were opened.

\section{April 2008}

The next, fourth meeting of the Council of Stabilization and Association.

\section{June 2008}

Chapters 2 - Freedom of Movement for Workers and 19 Social Policy and Employment were opened.

\section{July 2008}

Chapter 1 - Free Movement of Goods was opened, chapter 20

- Enterprise and Industrial Policy was temporarily closed.

\section{October 2008}

Chapter 30 - External Relations was temporarily closed. 


\section{December 2008}

Chapter 5 - Public Procurement was opened, chapter 7 Intellectual Property Law, 10 - Information Society and Media and 17 - Economic and Monetary Policy were temporarily closed.

\section{April 2009}

The fifth meeting of the Council of Stabilization and Association.

\section{October 2009}

Chapters: 4 - Free Movement of Capital, 11 - Agriculture and Rural Development, 12 - Food Safety, Veterinary and Phytosanitary Policy, 16 - Taxation, 22 - Regional Policy and Coordination of Structural Instruments and $24-$ Justice, Freedom and Security were opened. Chapters: 2 - Freedom of Movement for Workers, 6 - Company Law, 18 - Statistics, 21 - Trans-European Networks and $29-$ Customs Union were temporarily closed.

\section{November 2009}

Croatia and Slovenia signed an agreement on handing over the conflict concerning the Gulf of Piran to the international arbitrage.

\section{November 2009}

Chapters: 9 - Financial Services, 15 - Energy and 28 Consumer and Health Protection were temporarily closed.

\section{December 2009}

Chapters 3 - Right of Establishment \& Freedom To Provide Services and 19 - Social Policy and Employment were temporarily closed. 


\section{February 2010}

Chapters 13-Fisheries and 27 - Environment were opened.

\section{April 2010}

Chapter 1 - Free Movement of Goods was temporarily closed.

\section{June 2010}

Chapters temporarily closed: 12 - Food Safety, Veterinary and Phytosanitary Policy and 32 - Financial Control.

\section{June 2010}

Chapters: 8 - Competition Policy, 23 - Judiciary and Fundamental Rights, 31 - Foreign, Security and Defence Policy were opened. Chapters temporarily closed: 5 - Public Procurement and 16 - Taxation.

\section{November 2010}

Chapters temporarily closed: 4 - Free Movement of Capital, 14 - Transport Policy. Chapter 34 - Institutions was opened and temporarily closed.

\section{December 2010}

Chapters: 24 - Justice, Freedom and Security, 27 - Environment, 31 - Foreign, Security and Defence Policy were temporarily closed.

\section{June 2011}

The European Commission recommended closing the negotiations and setting the accession date for July 1, 2013.

\section{June 2011}

The European Council called for closing the accession negotiations and signing the accession treaty until the end of 2011. 


\section{June 2011}

End of accession negotiations.

\section{September 2011}

Polish Prime Minister Donald Tusk handed in a draft of Croatian accession treaty to the head of Croatian government Jadranka Kosor in Zagreb.

\section{October 2011}

The European Commission issued a positive opinion on planned accession of Croatia to the European Union.

\section{December 2011}

Signing acession treaty in Brussels.

1 July 2013

Planned date of accession of Croatia to the European Union. 


\begin{tabular}{|c|c|c|c|c|c|}
\hline \multirow{9}{*}{ 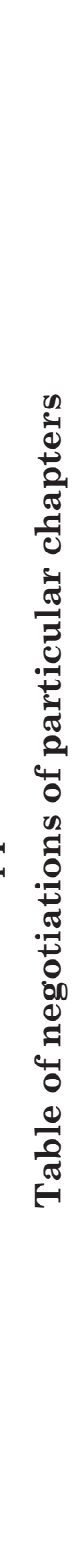 } & 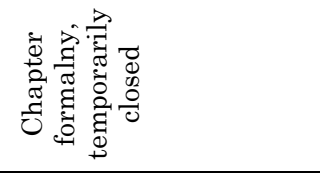 & o & 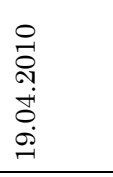 & 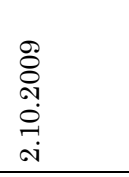 & 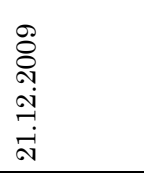 \\
\hline & 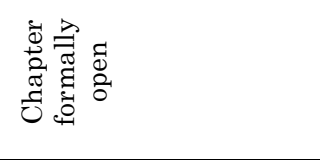 & $\infty$ & 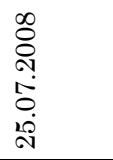 & 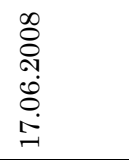 & 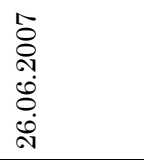 \\
\hline & 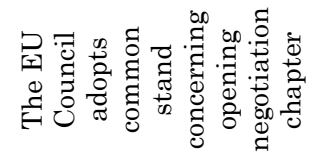 & 1 & 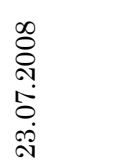 & $\begin{array}{l}\infty \\
\stackrel{\leftrightarrow}{1} \\
\dot{0} \\
\dot{0} \\
\dot{0}\end{array}$ & 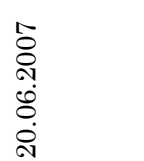 \\
\hline & 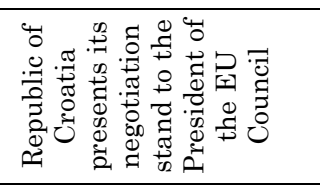 & 0 & 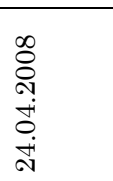 & 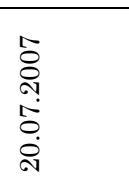 & 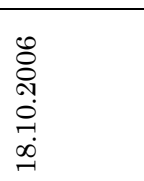 \\
\hline & 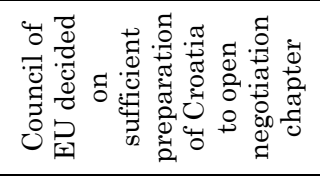 & 10 & 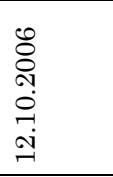 & 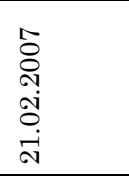 & 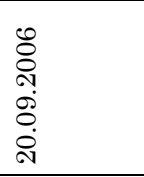 \\
\hline & 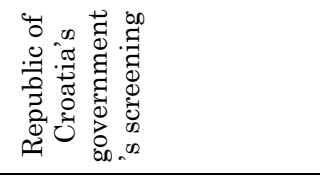 & 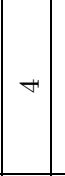 & 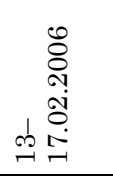 & 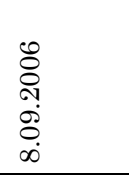 & 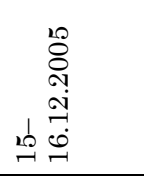 \\
\hline & 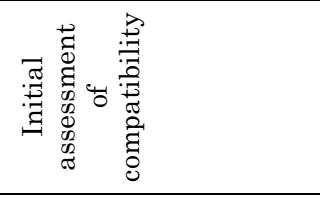 & $\infty$ & 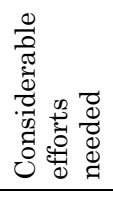 & 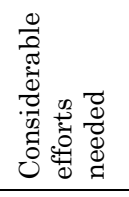 & 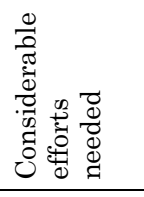 \\
\hline & 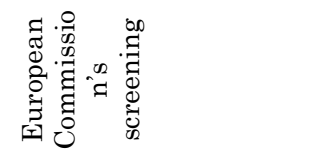 & 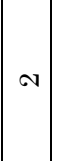 & 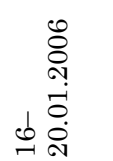 & 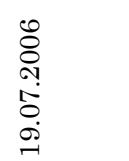 & $\begin{array}{l}\stackrel{2}{o} \\
\stackrel{0}{N} \\
\stackrel{-}{-} \\
\stackrel{-}{-1}\end{array}$ \\
\hline & 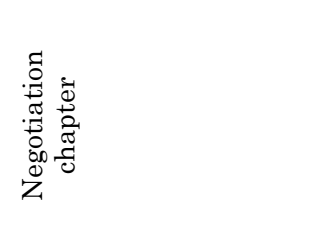 & -1 & 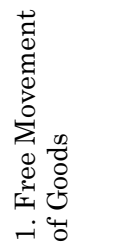 & 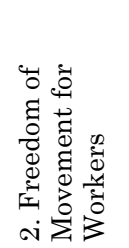 & 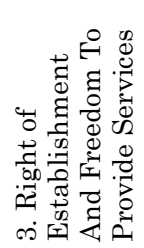 \\
\hline
\end{tabular}




\begin{tabular}{|c|c|c|c|c|c|c|c|}
\hline$\sigma$ & $\begin{array}{l}\stackrel{0}{\circ} \\
\stackrel{\circ}{\circ} \\
\stackrel{-1}{10}\end{array}$ & $\begin{array}{l}0 \\
\stackrel{0}{0} \\
\text { ஸे } \\
\dot{0} \\
0 \\
\dot{0}\end{array}$ & 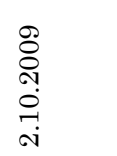 & 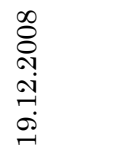 & $\begin{array}{l}\overrightarrow{7} \\
\stackrel{0}{0} \\
\dot{0} \\
0 \\
\dot{0} \\
\dot{0}\end{array}$ & $\begin{array}{l}\stackrel{8}{0} \\
\stackrel{\leftrightarrow}{+} \\
\overrightarrow{-1} \\
\stackrel{+}{+}\end{array}$ & 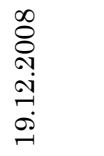 \\
\hline$\infty$ & 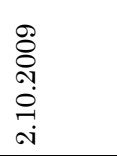 & 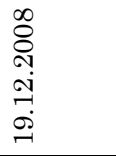 & 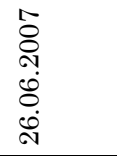 & 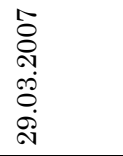 & 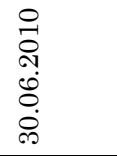 & 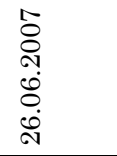 & 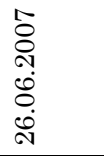 \\
\hline 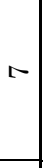 & 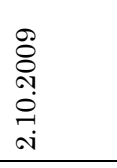 & 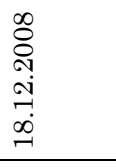 & 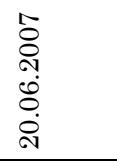 & 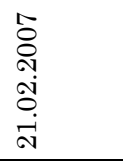 & 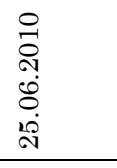 & 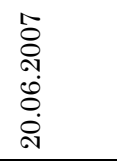 & 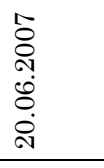 \\
\hline 0 & 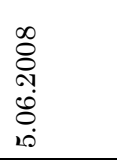 & 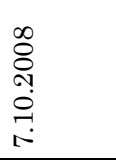 & 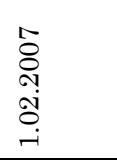 & 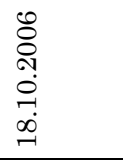 & 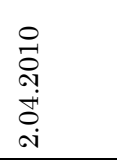 & 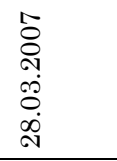 & 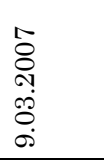 \\
\hline 10 & 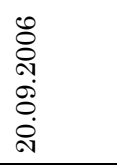 & 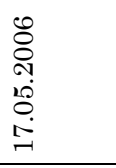 & 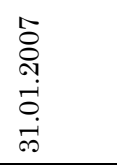 & 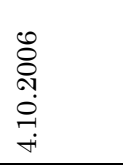 & 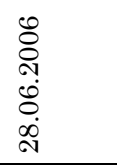 & 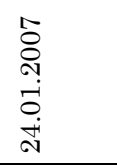 & 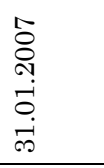 \\
\hline$r$ & 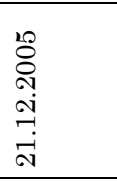 & 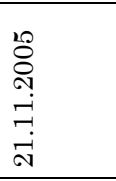 & 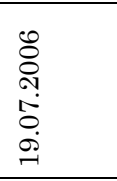 & 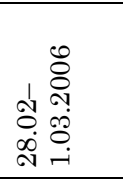 & 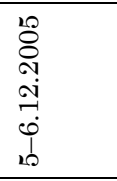 & 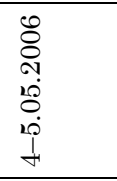 & 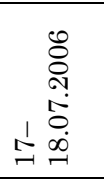 \\
\hline$\infty$ & 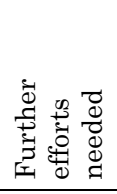 & 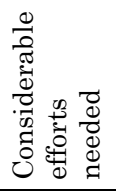 & 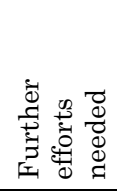 & 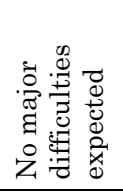 & 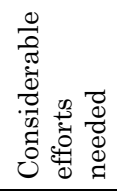 & 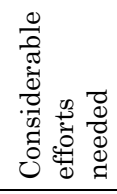 & 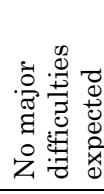 \\
\hline$\sim$ & 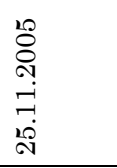 & 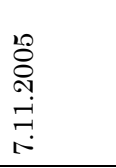 & 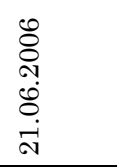 & 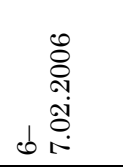 & 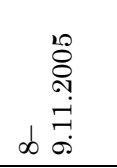 & 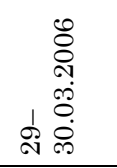 & 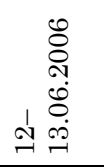 \\
\hline-1 & 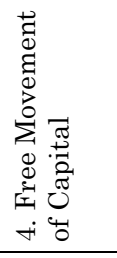 & 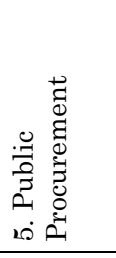 & 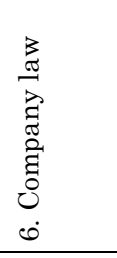 & 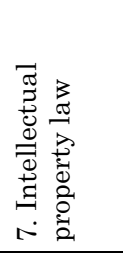 & 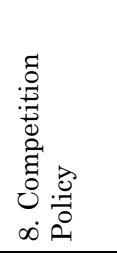 & 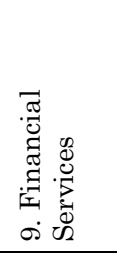 & 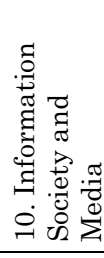 \\
\hline
\end{tabular}




\begin{tabular}{|c|c|c|c|c|c|c|}
\hline$\sigma$ & 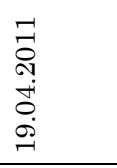 & 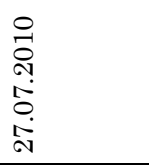 & 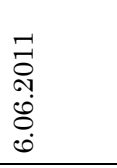 & 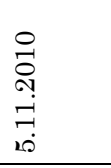 & 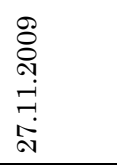 & 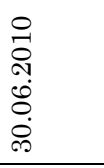 \\
\hline$\infty$ & 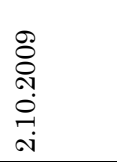 & 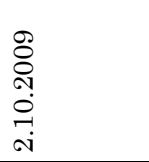 & 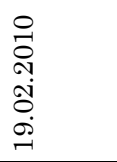 & $\begin{array}{l}\infty \\
\stackrel{8}{0} \\
\stackrel{N}{1} \\
\dot{0} \\
\dot{0} \\
\dot{\sim}\end{array}$ & 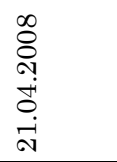 & 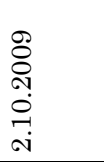 \\
\hline$\checkmark$ & 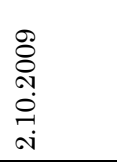 & 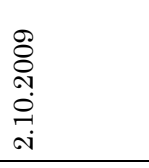 & 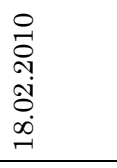 & \begin{tabular}{l}
$\infty$ \\
\multirow{2}{0}{} \\
$\stackrel{1}{1}$ \\
+ \\
0 \\
$\dot{0}$ \\
-1
\end{tabular} & 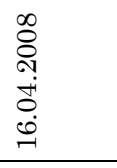 & 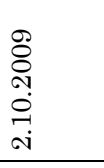 \\
\hline 0 & 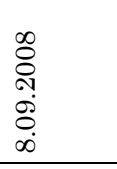 & 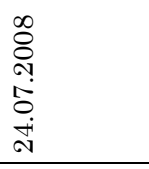 & 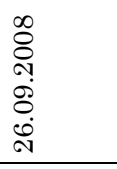 & 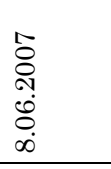 & 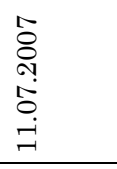 & 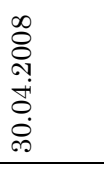 \\
\hline 10 & 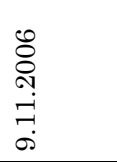 & 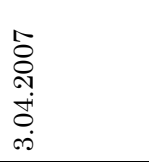 & 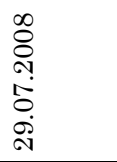 & 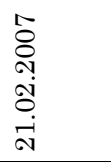 & 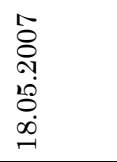 & 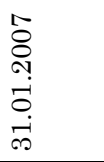 \\
\hline$r$ & 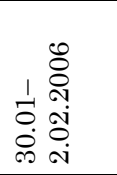 & 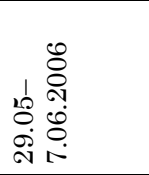 & 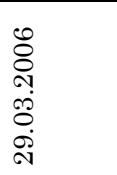 & 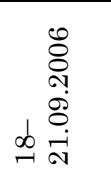 & 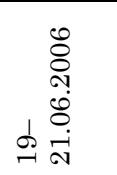 & 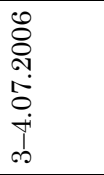 \\
\hline$\infty$ & 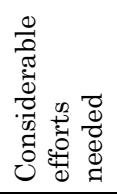 & 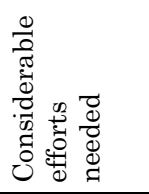 & 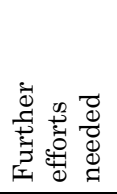 & 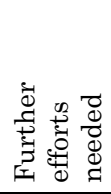 & 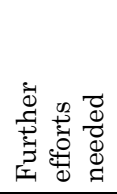 & 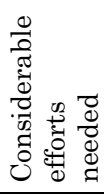 \\
\hline$\sim$ & 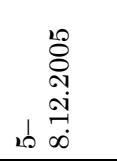 & 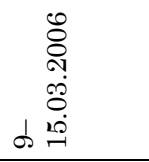 & 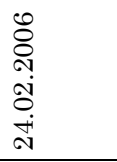 & 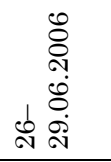 & 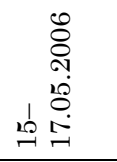 & 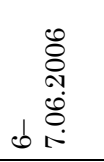 \\
\hline- & 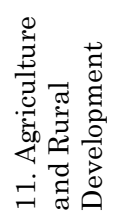 & 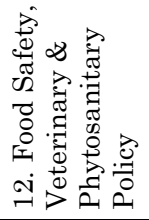 & 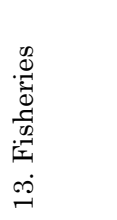 & 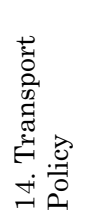 & 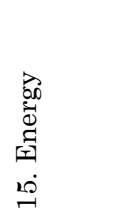 & 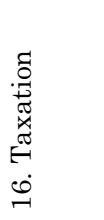 \\
\hline
\end{tabular}




\begin{tabular}{|c|c|c|c|c|c|c|}
\hline$\sigma$ & 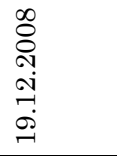 & $\begin{array}{l}\stackrel{0}{0} \\
\stackrel{0}{0} \\
0 \\
\stackrel{0}{1} \\
\text { ì }\end{array}$ & 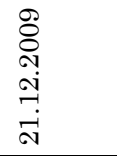 & 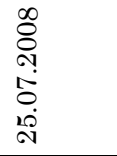 & 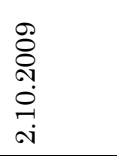 & 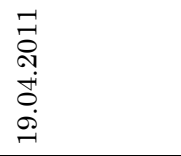 \\
\hline$\infty$ & 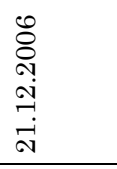 & 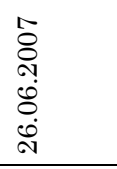 & 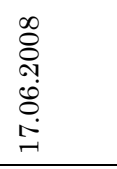 & 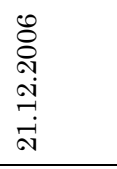 & 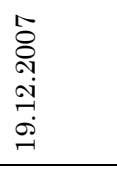 & $\begin{array}{l}\stackrel{8}{0} \\
\stackrel{0}{0} \\
0 \\
\stackrel{1}{1} \\
\text { ì }\end{array}$ \\
\hline$\checkmark$ & 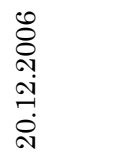 & 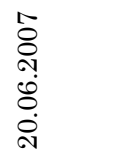 & 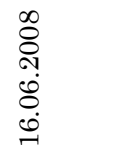 & 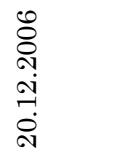 & 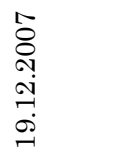 & $\begin{array}{l}8 \\
8 \\
0 \\
0 \\
0 \\
-1 \\
\text { i. }\end{array}$ \\
\hline 0 & 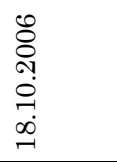 & 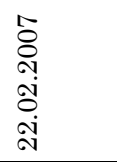 & 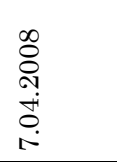 & $\begin{array}{l}0 \\
\& \\
\stackrel{1}{0} \\
0 \\
-1 \\
\infty \\
-1\end{array}$ & \begin{tabular}{l}
5 \\
8 \\
\multirow{2}{*}{} \\
0 \\
0 \\
0
\end{tabular} & 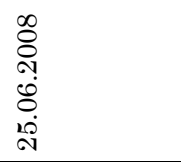 \\
\hline 10 & 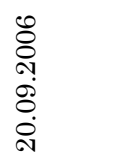 & 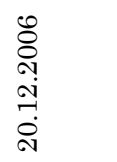 & 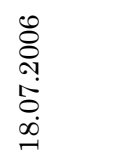 & 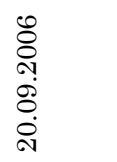 & 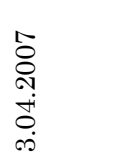 & 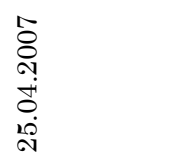 \\
\hline 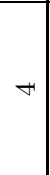 & 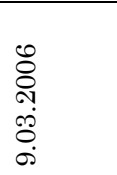 & 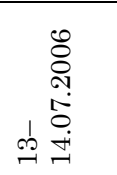 & $\begin{array}{l}0 \\
0 \\
0 \\
0 \\
0 \\
0 \\
0 \\
0 \\
0 \\
0\end{array}$ & 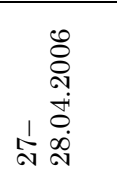 & 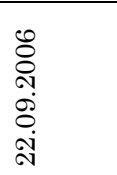 & $\begin{array}{l}0 \\
0 \\
0 \\
0 \\
0 \\
0 \\
1 \\
0 \\
1 \\
10\end{array}$ \\
\hline$\infty$ & 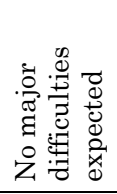 & 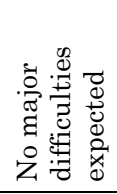 & 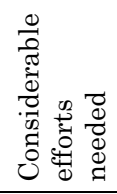 & 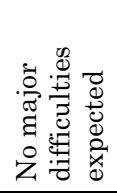 & 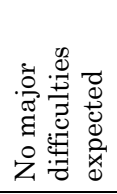 & 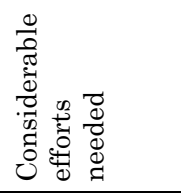 \\
\hline$\infty$ & 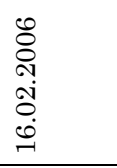 & 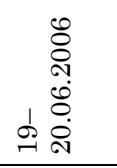 & 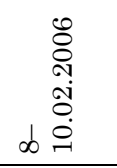 & 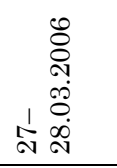 & $\begin{array}{l}0 \\
\& \\
\stackrel{\leftrightarrow}{n} \\
\dot{0} \\
\dot{0} \\
\dot{\infty}\end{array}$ & 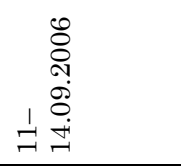 \\
\hline$\neg$ & 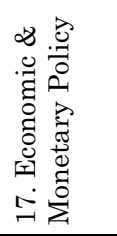 & 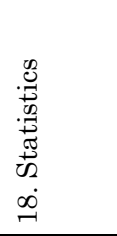 & 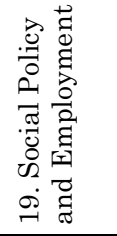 & 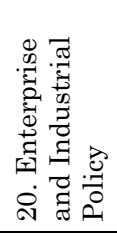 & 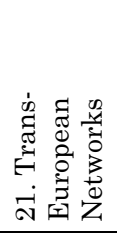 & 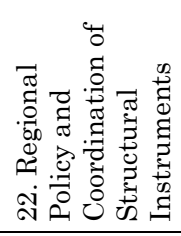 \\
\hline
\end{tabular}




\begin{tabular}{|c|c|c|c|c|c|c|c|}
\hline$\sigma$ & $\begin{array}{l}\overrightarrow{1} \\
\stackrel{1}{\circ} \\
\dot{0} \\
\dot{0} \\
\dot{0}\end{array}$ & 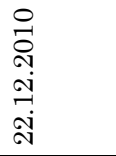 & 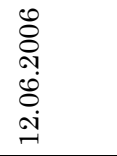 & 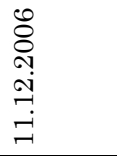 & 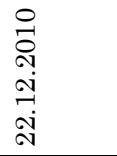 & 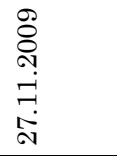 & 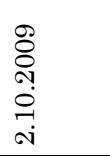 \\
\hline$\infty$ & 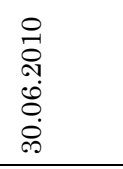 & 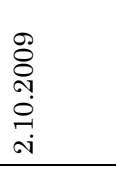 & 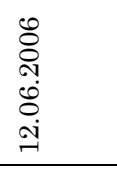 & 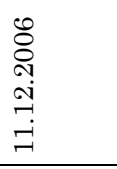 & 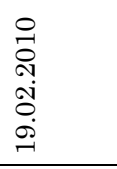 & 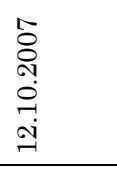 & 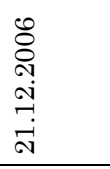 \\
\hline 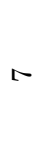 & 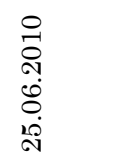 & 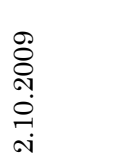 & 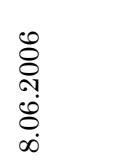 & 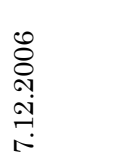 & $\begin{array}{l}0 \\
\stackrel{0}{0} \\
\text { N } \\
\text { ô } \\
\infty \\
\infty \\
-1\end{array}$ & 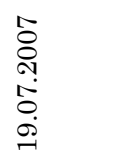 & 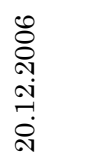 \\
\hline 0 & 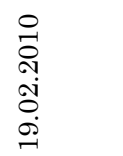 & 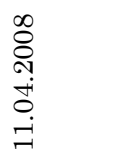 & 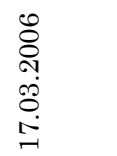 & $\begin{array}{l}0 \\
8 \\
\circ \\
\text {. } \\
0 \\
\dot{0} \\
\dot{N}\end{array}$ & 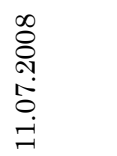 & 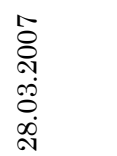 & $\begin{array}{l}0 \\
8 \\
\stackrel{0}{0} \\
0 \\
0 \\
\stackrel{1}{~}\end{array}$ \\
\hline 10 & 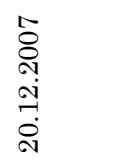 & $\begin{array}{l}0 \\
8 \\
0 \\
-1 \\
5 \\
0 \\
\infty \\
0 \\
-1\end{array}$ & 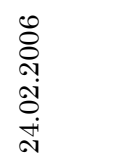 & 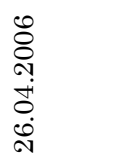 & 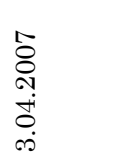 & 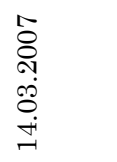 & 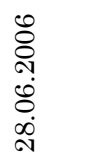 \\
\hline$H$ & 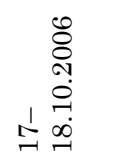 & 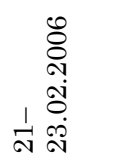 & 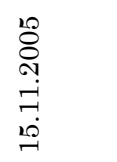 & 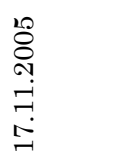 & 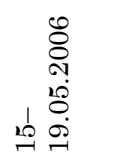 & 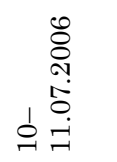 & 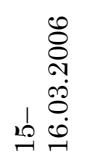 \\
\hline$\infty$ & 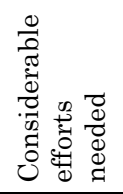 & 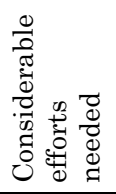 & 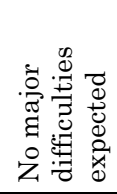 & 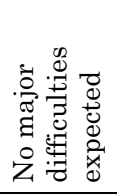 & 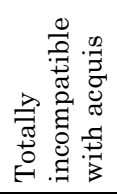 & 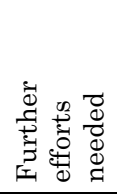 & 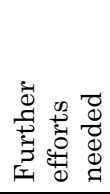 \\
\hline$N$ & 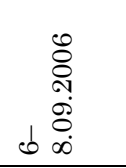 & 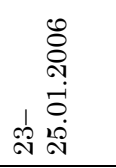 & 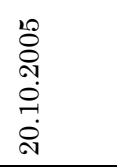 & 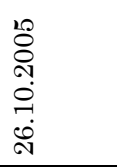 & 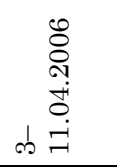 & 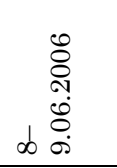 & 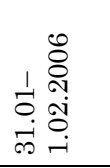 \\
\hline$\neg$ & 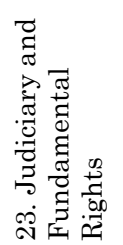 & 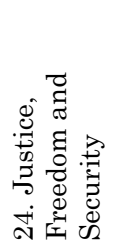 & 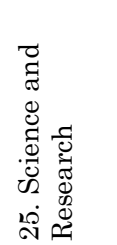 & 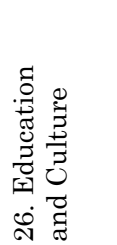 & 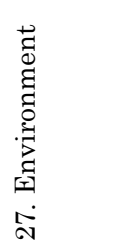 & 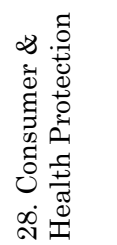 & 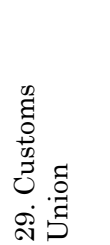 \\
\hline
\end{tabular}




\begin{tabular}{|c|c|c|c|c|c|c|}
\hline$\sigma$ & $\begin{array}{l}\infty \\
\stackrel{0}{0} \\
\stackrel{1}{0} \\
0 \\
\stackrel{1}{0} \\
0\end{array}$ & 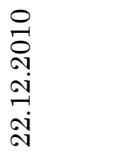 & 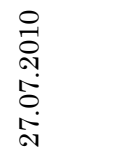 & 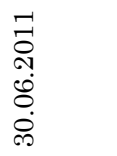 & $\begin{array}{l}\stackrel{0}{1} \\
\stackrel{\circ}{\circ} \\
\stackrel{-1}{10} \\
10\end{array}$ & $\begin{array}{l}ت 1 \\
\stackrel{0}{0} \\
\dot{0} \\
0 \\
\dot{0}\end{array}$ \\
\hline$\infty$ & 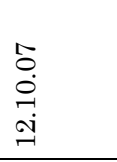 & 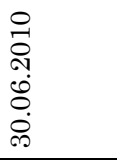 & 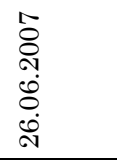 & 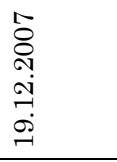 & 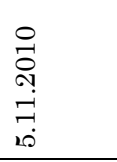 & 1 \\
\hline 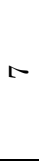 & $\begin{array}{l}5 \\
\vdots \\
\ddots \\
ت \\
-\end{array}$ & 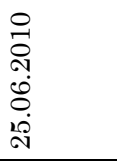 & 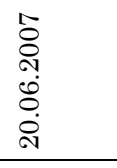 & 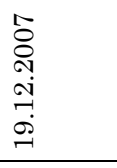 & $\begin{array}{l}0 \\
\stackrel{1}{ } \\
\text { ก̣ } \\
0 \\
\ddots \\
0\end{array}$ & 1 \\
\hline 0 & 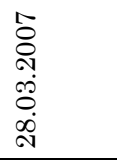 & \begin{tabular}{l}
$\infty$ \\
0 \\
0 \\
\multirow{N}{1}{} \\
10 \\
0 \\
$\infty$ \\
\end{tabular} & 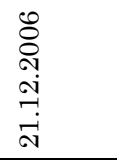 & $\begin{array}{l}5 \\
0 \\
0 \\
\text { on } \\
\infty \\
0 \\
i \\
\end{array}$ & 1 & 1 \\
\hline 10 & 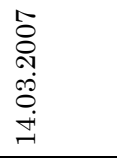 & 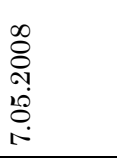 & 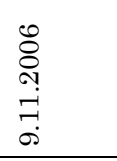 & 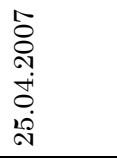 & 1 & 1 \\
\hline+ & 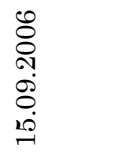 & 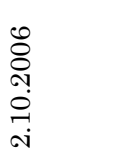 & 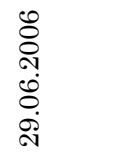 & 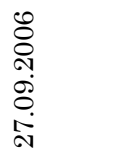 & 1 & 1 \\
\hline$\infty$ & 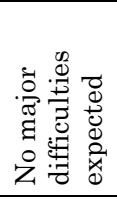 & 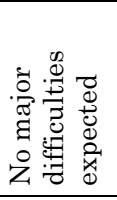 & 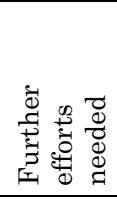 & 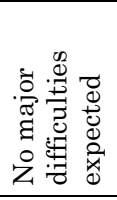 & 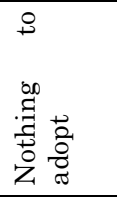 & 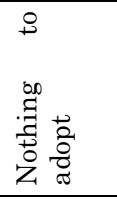 \\
\hline$\sim$ & 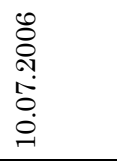 & 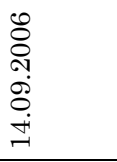 & $\begin{array}{l}0 \\
\& \\
0 \\
10 \\
10 \\
\infty \\
\infty \\
-1 \\
\end{array}$ & $\begin{array}{l}0 \\
0 \\
\circ \\
0 \\
0 \\
0 \\
0\end{array}$ & 1 & 1 \\
\hline-1 & 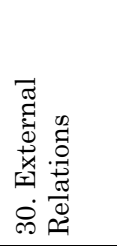 & 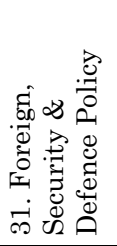 & 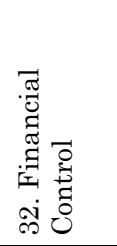 & 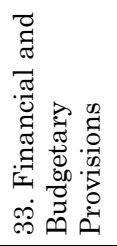 & 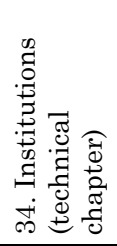 & 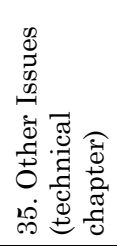 \\
\hline
\end{tabular}




\section{Appendix 3}

\section{EU Programmes, in which Croatia participates}

Currently Croatia as a candidate state participated in 2011 in following EU programmes:

- The Seventh Framework Programme for research, technological development and demonstrative activities (FP7)

- Competitiveness and Innovation Framework Programme (CIP)

- PROGRESS

- Culture 2007-2013

- Europe for Citizens

- Fiscalis 2013

- Customs 2013

- Civil Protection Financial Instrument

- MEDIA 2007

- The Second Programme of Community Action in the Field of Health 2008-2013

- Marco Polo II

- Community Mechanism for Civil Protection

- Lifelong Learning Programme, Youth in Action

- ISA - Interoperability Solutions for European Public Administrations

\section{Appendix 4}

\section{Croatian leaders between 1991 and 2011}

\section{Presidents of Croatia}

1990-1999 Franjo Tuđman

1999-2000 Vlatko Pavletić, Zlatko Tomčić (temporary, after

Tuđman's death)

2000-2010 Stjepan (Stipe) Mesić

2010- Ivo Josipović 
Prime Ministers of Croatia

$\begin{array}{ll}1990 & \text { Stjepan (Stipe) Mesić } \\ 1990-1991 & \text { Josip Manolić } \\ 1991-1992 & \text { Franjo Gregurić } \\ 1992-1993 & \text { Hrvoje Sarinić } \\ 1993-1995 & \text { Nikica Valentić } \\ 1995-2000 & \text { Zlatko Mateša } \\ 2000-2003 & \text { Ivica Račan } \\ 2003-2009 & \text { Ivo Sanader } \\ 2009-2011 & \text { Jadranka Kosor } \\ 2011- & \text { Zoran Milanović }\end{array}$

